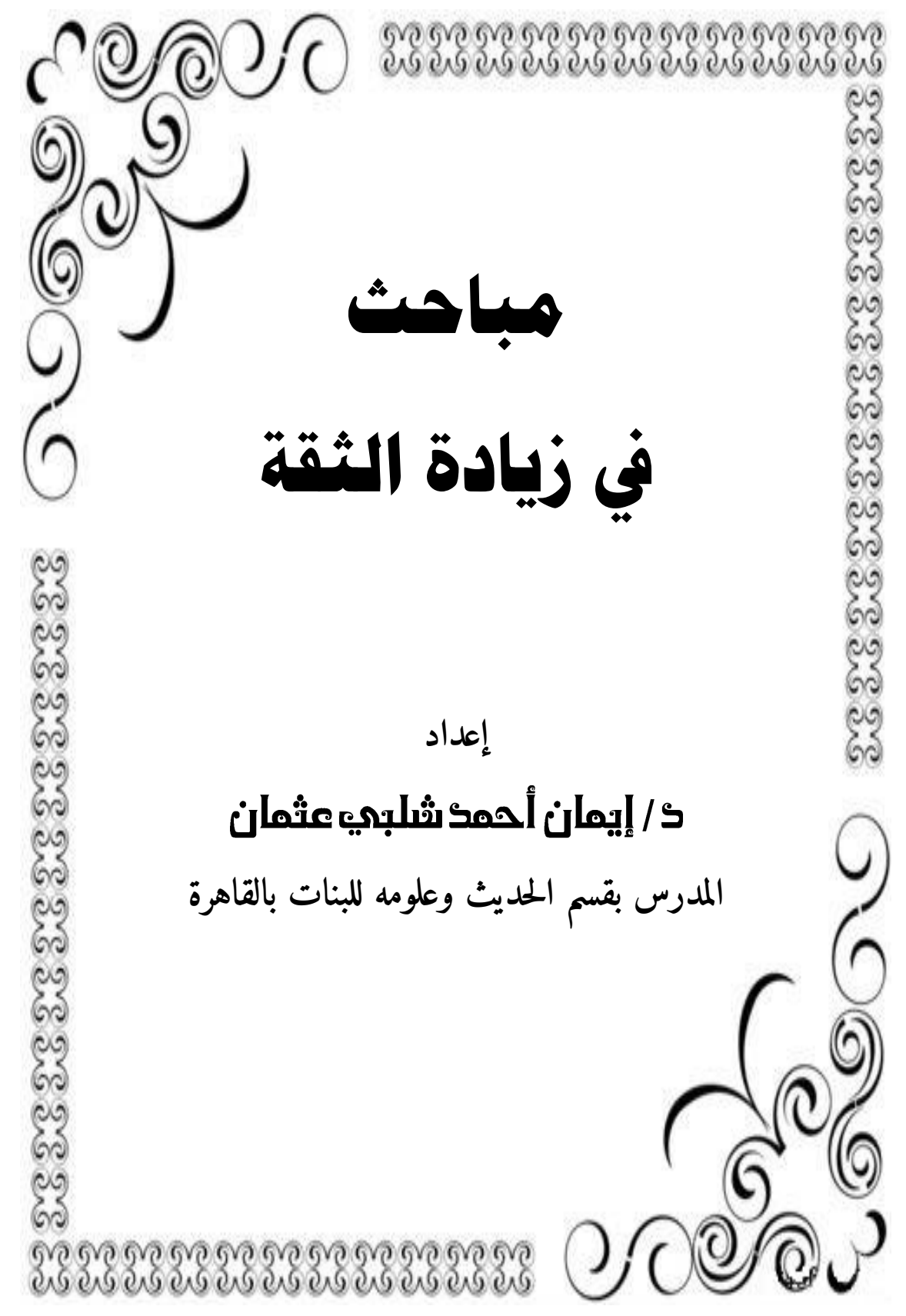


مباحث في زيادة الثقة

ب

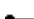




\section{مباحث في زيادة الثقة}

إيمان أحمد شلبي عثمان

قسم الحديث وعلومه ، كلية الدراسات الإسلامية والعربية للبنات بالقاهرة -

مصر

البريد الإكتروني: eman.shalaby@azhar.edu.eg

الملخص:

يعد هذا البحث محاولة لدراسة موضوع زيادة الثقة وما يتصل بها من أنواع

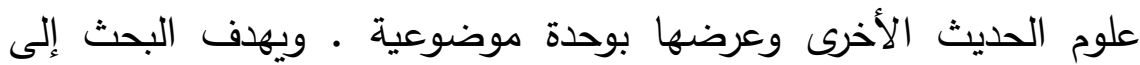
إظهار الترابط بين زيادة الثقة وبين هذه الأنواع الحديثية التي ذكرت في كتب مصطلح الحديث كموضوعات مستقلة ، كالحديث المعلول بتعارض الوصل والإرسال ، أوتعارض الرفع و الوقف ، وكالحديث الثاذ ، والمزيد

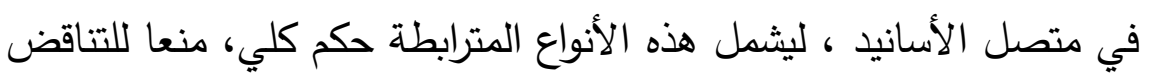
والتعارض فى الحكم عليها، كما يهدف البحث إلى الوصول إلى الرأي الراجح في حكم زيادة الثقة. وقد اعتمدت على المنهج المقارن والمنهج التحليلي في بيان العلاقة بين زيادة الثقة وغيرها من أنواع علوم الحديث المرتبطة بها ،والمنهج النقدي في عرض آراء العلماء في حكم زيادة الثقة . ومن أهم نتائج البحث: أن إطلاق بعض المحدثن القول بأن الزيادة من الثقة مقبولة ليس قولا مطلقا منهم في كل زيادة، حتى وإن كان روايها عدلا ضابطا، وإنما هي في زيادة الثقة المبرز في الحفظ والإتقان على غيره ، ولكل زيادة حكم خاص بها من حيث القبول أو الرد، وفقا لما ترجح من الملابسات والقرائن التي يُحكم بمقتضاها على راوي الزيادة بأنه قد أتقن 
وحفظ مالم يحفظه الآخرون فتقبل زيادته ،أو أنه قد وهم واختل ضبطه فترد

زيادته .

الكلمات المفتاحية : الثقة - الثاذ - المزيد -المنكر - المعلول . 
 \\ Investigations on Additions Made by Trustworthy Narrators \\ Eman Ahmad Shalabi Othman \\ Department of Hadith and its Sciences ، Faculty of Islamic and Arabic Studies for Girls in Cairo، Egypt. \\ Email: eman.shalaby@azhar.edu.eg}

\section{Abstract:}

The present study is an attempt to examine the subject of additions made by trustworthy narrators and its relation to other types of Hadith sciences and elaborating the topic objectively.

The study aims at showing the connection between additions made by trustworthy narrators and the types of hadiths which have been mentioned in the Hadith terminology literature as independent topics، such as defective hadith because of a contradiction in continuity ${ }^{1}$ and attribution ${ }^{2}$ or a contradiction in attribution to the Prophet (Peace be upon him) and discontinuation ${ }^{3}$. Other examples include the irregular hadith ${ }^{4}$ and the hadith that is added in a continuous chain of transmission. This is in order to have a holistic judgement for these connected

1 To narrate the hadith with a continuous chain of transmission that suffers no interruption

2 a tābiinn narrator, whether young or old, directly attributes to the prophet (peace be upon him) bypassing a companion of the prophet.

3 A statement, action or approval attributed to a companion of the prophet, whether its chain of transmission is complete or incomplete. The term is also restrictedly used in reference to what is attributed to a narrator from the tābiīn generation, or lower.

4 what is peculiar and contrary to the majority. 
types to avoid inconsistency and contradiction that may happen while judging them. The study also aims at reaching the most preponderant opinion in the status of the additions made by trustworthy narrators.

The study adopts the comparative approach and the analytical approach to show the relation between the additions made by trustworthy narrators and the other related types of Hadith sciences. It also adopts the critical approach in reviewing the opinions of scholars in the status of the additions made by trustworthy narrators.

The most important conclusion arrived at is that the generalization made by some hadith scholars about the acceptability of the additions made by trustworthy narrators is not applicable to every addition even if its narrator is a truly pious person who has been known for his uprightness and exactitude. The generalization applies to the additions made by a trustworthy narrator who surpasses other narrators in memory and exactitude. Every addition has its own judgement in terms of acceptance or rejection; it is judged in accordance to the weighted circumstances and inferences according to which the narrator of the additions is judged so as to see whether he has mastered and memorized what others did not preserve (in this case his addition is accepted) or he has been deluded and his exactitude is doubted (in this case his addition is rejected).

Keywords: Trustworthy narrator - irregular hadith hadith that is added in a continuous chain of transmission - odd hadith- defective hadith 


\section{المقدمة}

إنَّ الحمد الله نَحْمَدُهُ ونستتعينُهُ ونستغفرُهُ، ونَعوذُ باللهِ مِنْ شرورِ أنفِسِنَا

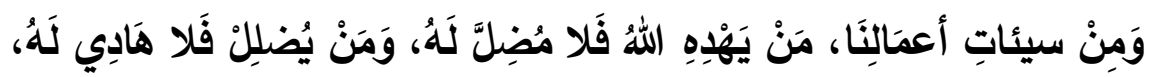

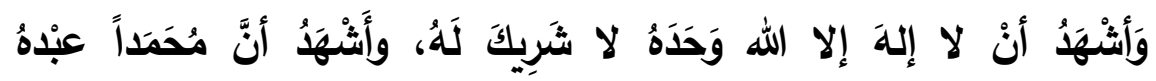
ورسولُهُ.

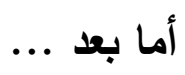

فإن علم الحديث دراية(') من أشرف العلوم التي انفرد بها المسلمون، وامتازوا بها عن غيرهم من الأمم ، به اعتني أئمة المحدثين والنقاد من المتقدمين والمتأخرين لعلمهم بأهميته وفائدته وعظيم نفعه ، فهو الدم أداة تمحيص السنة النبوية المطهرة، وتنقيحها من كل خبر لم تثبت صحته

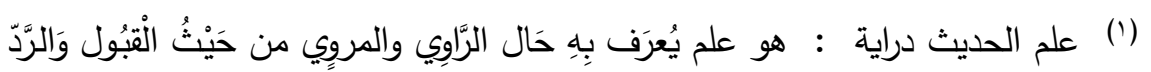
وَمَا يتَعَلَّق بذلك فِي معرفَة اصْطِلَّح أَهله.

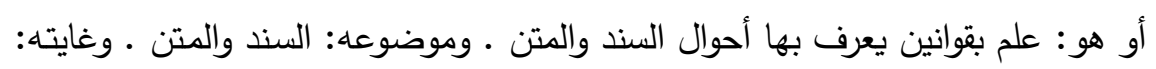
معرفة الصحيح من غيره. (اليواقيت والدرر في شرح نخبة ابن حجر لزين الدين محمد المدعو بعبد الرؤوف بن

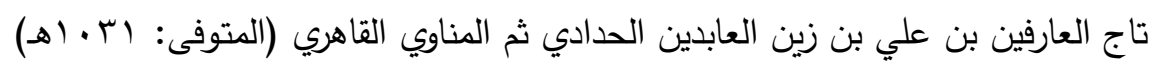

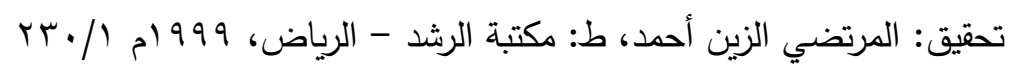

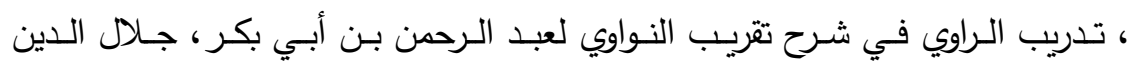

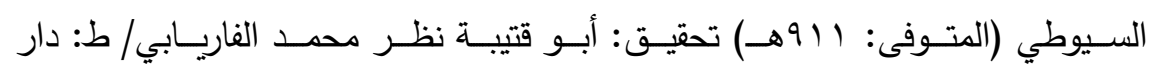

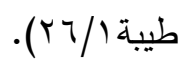


إلى النبي صلى الله عليه وسلم ، وبـه يعرف المقبول والمردود(') من الأحاديث

ويعد مبحث زيادة الثقة من أهم مباحث علوم الحديث التي يجب الإعتناء بها، لما يترتب عليه من الأحكام الثرعية التي يتوقف قبولها والعمل بها على قبول أو رد تلك الزيادات، ولقد فطن المحثثون لأهمية هذا المبحث فأولوه عناية واهتماما ، وأشاروا إلى فائدته وضرورة الإعتناء به. قال ابن الصلاح: ذلك فن لطيف تستحسن العناية به(؟). وقال ملا علي القاري: "اعلم أن معرفة زيادة الثقة فن لطيف يستحسن العناية به لما يستفاد بالزيادة من الأحكام، وتقييد الإطلاق، وإيضاح المعاني، وغير ذلك، وإنما يعرف بجمع الطرق والأبواب، وقد كان إمام الأئمة ابن خزيمة لجمعه بين الفقه والحديث مشارا إليه بحيث قال تلميذه ابن حبان: ما رأيت على أديم الأرض(ז) من يحفظ الصحاح بألفاظها،

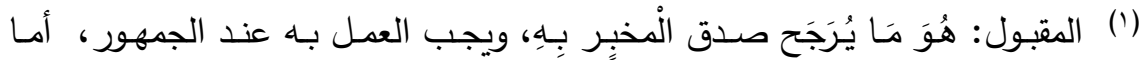

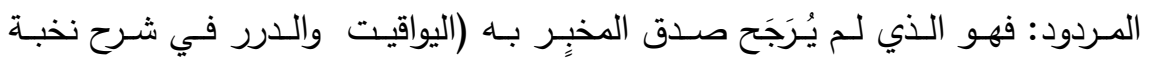
الفكر / 9 צr). (ז) معرفـة أنواع علوم الحديث، (المعروف بمقدمـة ابن الصـلاح) تحقيق : نور الدين

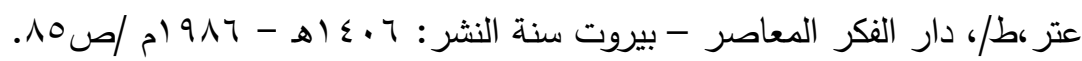

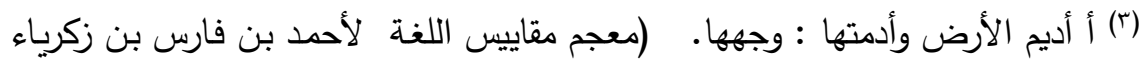

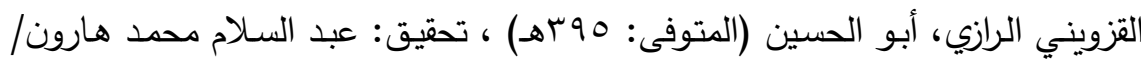

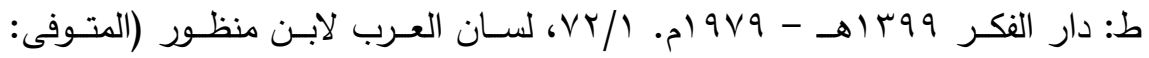

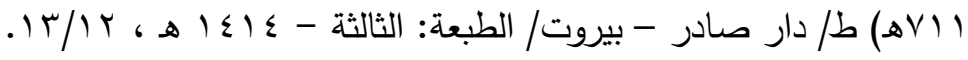


ويقوم بزيادة كل لفظة زادها في الخبر ثقةٌّ ما غيره، حتى كأن السنن

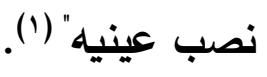

وقـال الحساكم: "وهــا ممــا يعـز وجـوده ويقـل فـي أهـل الصـنعة مـن

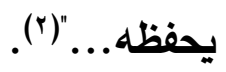

وعلى الرغم من أهية هذا المبحث إلا أنه ما زال من المباحث التي

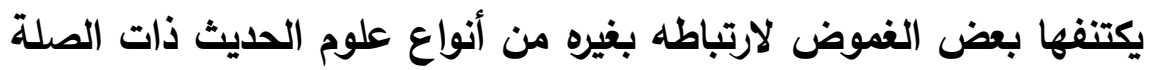

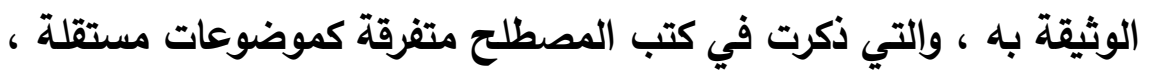
ولم تجمع في كتب التراث الحديثية في وحدة موضوعية ليجمعها حكم

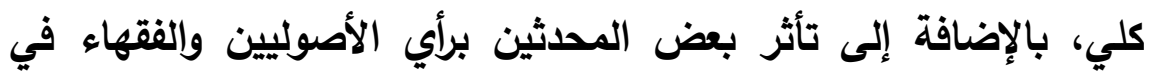

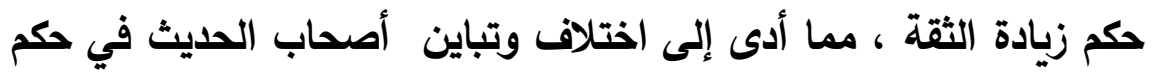

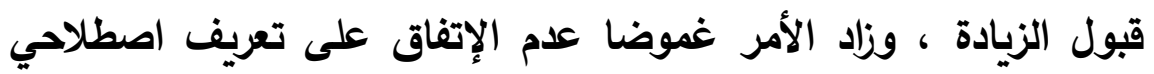

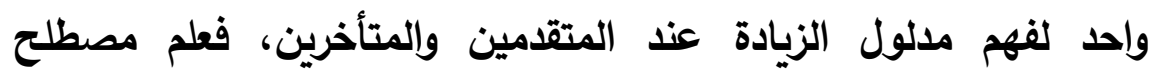

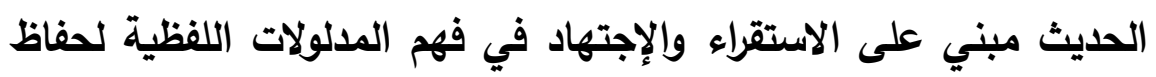

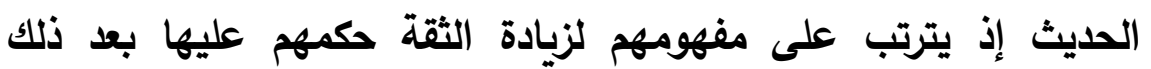
بالقبول أو الرد ، وسألقي الضوء في هذا البحث على على ماهية زيادة الثقة لئة

(') شرح نخبة الفكر في مصطلحات أهل الأثرلعلي بن سلطان محدد، أبو الحسن نور

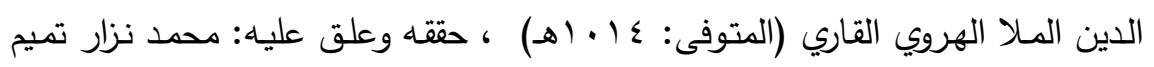

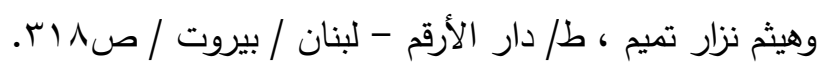

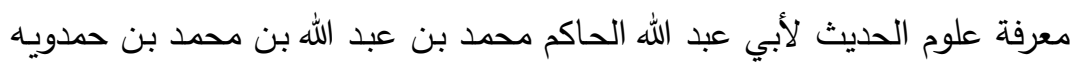

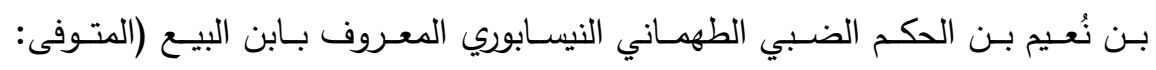

$$
\begin{aligned}
& \text { ه ـ ـهـ)تحقيق : السيد معظم حسين/ ط دار الكتب العلمية - بيروت }
\end{aligned}
$$

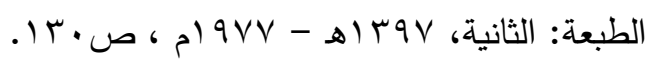


وضوابطها ، وإظهار العلاقة بين زيادة الثقة وغيرها من أنواع علوم الحديث وثيقة الصلة بها كالثاذ، والمعلول بتعارض الوصل والإرسال أو تعارض الرفع والوقف، لإظهار الترابط بين هذه الأنواع ، وكذا بيان العلاقة بين زيادة الثقة في الإسناد وبين المزبد في متصل الأسانيد، ثم لإمان عرض آراء المحثثين في حكم زيادة الثقة، ومناقشة القائلين بأن زيادات

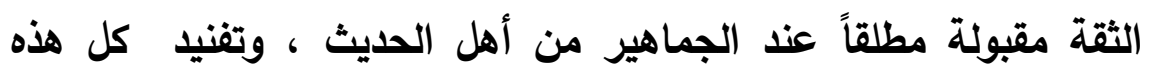
الآراء ، للوصول إلى الراجح منها . فاله أسأل السداد والتوفيق، وما توفيقي إلا بالله عليه توكلت وإليه أنيب. 


\section{سبب اختياري لموضوع البحث}

قد وفقني الله عزوجل لاختيار هذا الموضوع لعدة أسباب:

1- إن موضوع زيادة الثقة وإن ورد في كتب مصطلح الحديث مستقلا

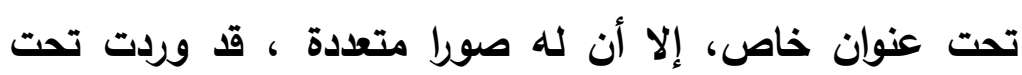
موضوعات ومسميات مختلفة في كتب المصطلح، كالحديث المعلول بتعارض الوصل والإرسال، أوتعارض الرفع والوقف، وكالحديث الشاذ، فأردت بلورة هذه الموضوعات ودراستها في وحدة موضوعية، ليجمعها حكم كلي، منعا للتناقض والتعارض فى ونى الحكم عليها- مون.

ץ-بالرغم من أهمية مسألة زيادة الثقة، وعِيمٍ أثرها، لما ينبني عليها من الأحكام الشرعية ، إلا أنتا نجد اختلافا كبيرا بين المحدثين في حكم الزيادة فتناولت في هذا البحث آراء المحدثين في حم الزيادة، ومناقشتها، وتفنيدها ، للوصول إلى الراجح منها. 


\section{خطة البحث}

بضضل الله وعونه ، قمت بتقسيم هذا البحث إلى مقدمة، وثلاثة مباحث، وخاتمة،ثم فهرس الموضوعات، ومصادر البحث ومراجعه. أولا : المقدمة : وتثتمل على: - أهمية موضوع البحث r-أسباب اختياري لموضوع البحث.

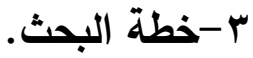
ثانيا: مباحث البحث المبحث الأول :ويشتمل على مطلبين: المطلب الأول:تعريف زيادة الثقة. المطلب الثاني: ضوابط ماهية زيادة الثقة. المبحث الثاني : العلاقة بين زيادة الثقة وبين غيرها من أنواع علوم الحديث المرتبطة بها ، ويشتمل على ثلاثة مطالب : المطلب الأول:العلاقة بين زيادة الثقة والحديث المعلول بتعارض الوصل والإرسال أوالرفع والوقف .

المطلب الثاني: العلاقة بين زيادة الثقة والحديث الثاذ . المطلب الثالث: العلاقة بين زيادة الثقة والمزيد في متصل الأسانيا . المبث الثالث : في حكم زيادة الثقة 
وعرضت فيه آراء المحثثين في حكم زيادة الثقة، وبيان اختلافهم وتباينهم في الحكم عليها ، ومناقشة القائلين بأن قبول الزيادة مذهب لجمهور المحثثين ، وتفنيد كل هذه الآراء ، وبيان الراجح منها . -الخاتمة : وفيها أهم النتائج والتوصيات. - فهرس الموضوعات . - المصادر والمراجع - 
المبحث الأول: تعريف زيادة الثقة وضوابطها

أولا: تعريف زيادة الثقة:

الزيادة لغة: هي النمو، وهو خلاف النقصان(').

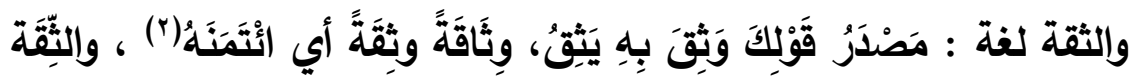

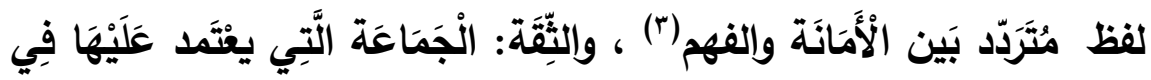

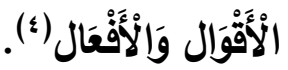

والثقة في اصطلاح المحثثين : هو العدل الضابط(ه) ، وقد أجمع جماهير أئمة الحديث والفقه على أنه يثترط فيمن يحتج بروايته أن يكون عدلا ضابطا لما يرويه،

$$
\begin{aligned}
& \text { (1) لسان العرب س/ 191. }
\end{aligned}
$$

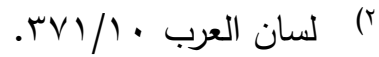

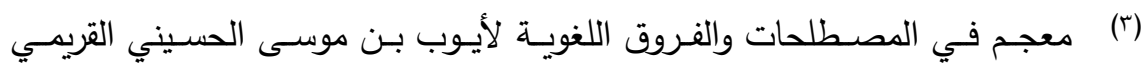

$$
\text { الكفوي، أبو البقاء الحنفي (المتوفى: ـ } 9 \text { ـ (هـ) }
$$

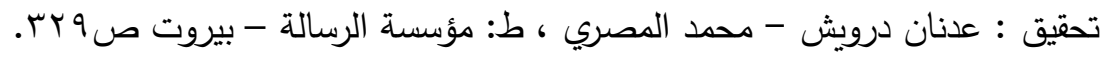

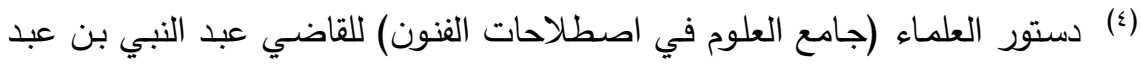

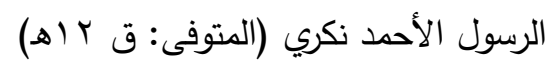

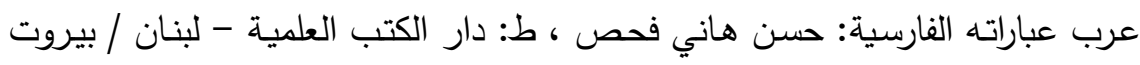

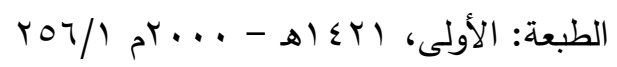

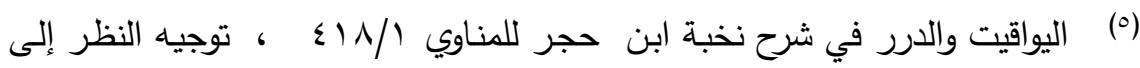

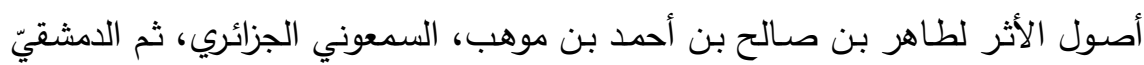

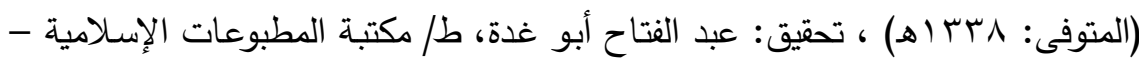

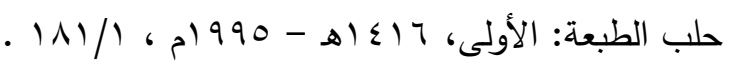


وتفصيله: أن يكون مسلما، بالغا، عاقلا، سالما من أسباب الفسق وخوارم المروءة، متيقظا غير مغفل، حافظا إن حدث من حفظه، ضابطا لكتابه إن حدث من كتابه. وإن كان يحدث بالمعنى اشترط فيه مع ذلك أن يكون عالما بما يحيل المعاني (') وقد اختف المحدثون في تعريفهم الإصطلاحي لزيادة الثقة على النحو التالي: - n 1-تعريف الحاكم: معرفة زيادات ألفاظ فقهية في أحاديث ينفرد بالزيادة راو واحد (). قلت: وفي هذا التعريف نظر، إذ خص الحاكم الزيادة بكونها ألفاظا فقهية، والصواب أن كل ما زاده الراوي الثقة على ما رواه غيره فهي زيادة، ولو لم تكن ألفاظا فقهية ، كما لو كانت الزيادة مثلا بيانا للمعنى .. كما ترك الحاكم قيد توثيق الراوي، فأطلق لفظ "الراوي" دون تقييده "بالثقة"، فيثمل الراوي ثقة كان أم ضعيفا، بينما هذا المبحث كما هو لرئ لرئ

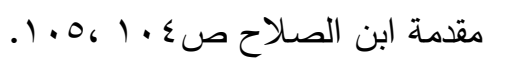

وتثبت عدالة الراوي باشتهاره بالخير ، والثثاء الجميل عليه، أو بتعديل الأئعة، أو اثنين

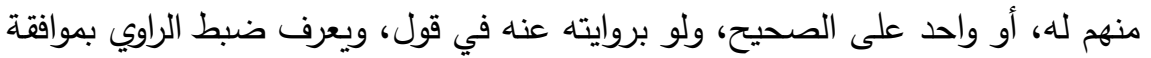

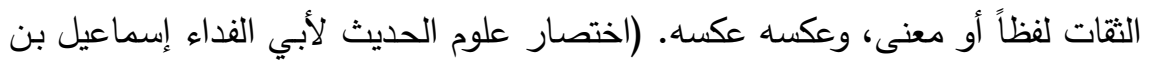

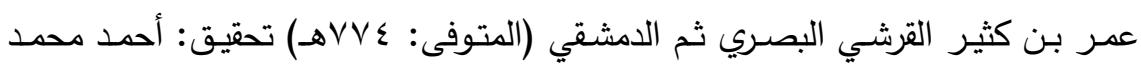
شاكر، ط: دار الكتب العلمية، بيروت - لبنان الطبعة: الثانية ، صع 9، جـ9).

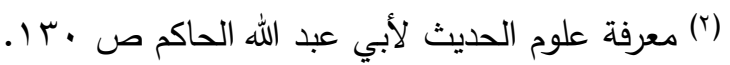


مستمد من عنوإنه خاص بزيادة الثقة، فتخرج زيادة الضعيف التي ينفرد بها إذ هي رواية منكرة(') r-تعريف ابن كثير: إذا تفرد الراوي بزيادة في الحديث عن بقية الرواة

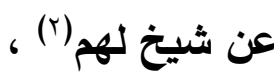
قلت: ويؤخذ على هذا التعريف ما أخذ على سابقه من ترك قيد توثيق

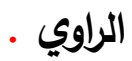
r-تعريف ابن رجب الحنبلي: هي أن يروي جماعة حديثاً وإحاً بإسناد

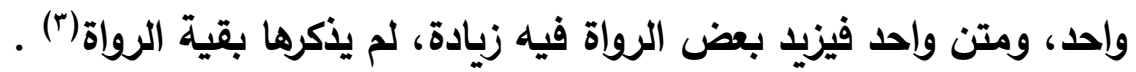
قلت: ويؤخذ عليه ما أخذ على سابقيه من ترك قيد توثيق الراوي، كما أنه خص الزيادة بصدورها عن "بعض" الرواة لا عن أحدهم منفردا بها ، فليس ثمة تفرد بالزيادة.

(') يقول ابن حجر : وأما إذا انفرد المستور أو الموصوف بسوء الحفظ أو المضعف

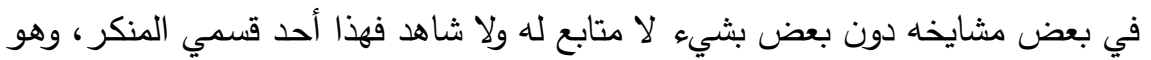

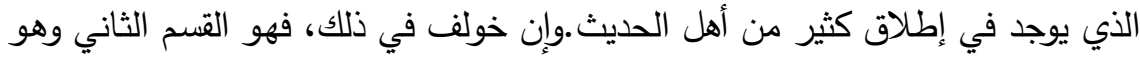

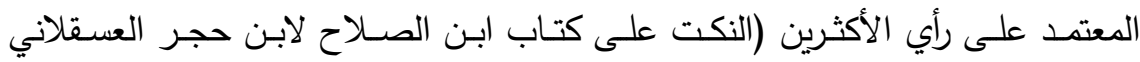

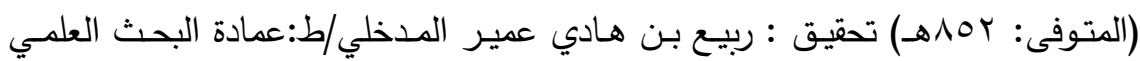

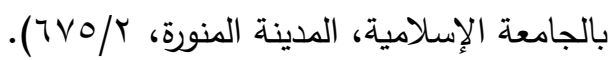

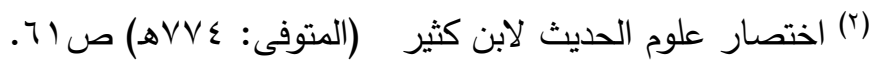

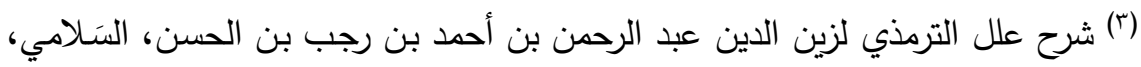
البغدادي، ثم الدمشقي، الحنبلي (المتوفى:

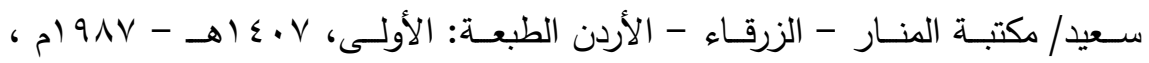
. $750 / 5$ 
ع -تعربف الإمام المناوي: زِيَادَة الْعدْل الضَّابِط فِيمَا رَوَاهُ على غَيره من

(الْعُدُول (1)

ويعد تعريف الإمام المناوي من أجمع التعاريف لزيادة الثقة ، لكنه لم ينص على أن الزيادة قد تكون في المتن ، أو في الإسناد.

ومما سبق يمكن تعريف زيادة الثقة بأنها: تفرد الراوي الثقة بزيادة في

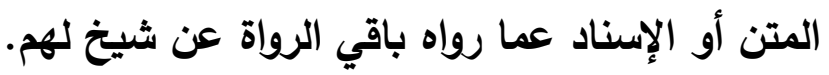

ومن هنا كان لزاما أن نضع ضوابطا لتحديد ماهية زيادة الثقة، حتى لا تختلط ببعض صور الزيادة التي لا علاقة لها بمفهوم زيادة الثقة . ثانيا: ضوابط ماهية زيادة الثقة:

1- أن يكون راوي الزيادة ثقة، أما إن كان راوي الزيادة ضعيفا فهي

رواية منكرة كما مر بيانه.

ץ- أن ينفرد بهذه الزيادة ولا يتابع عليها : فلو تابع راوي الزيادة راوٍ آخر فروى تلك الزيادة أصبحت هذه الزيادة محفوظة فتزداد قوتها ، ويبعَّ اتهام الراوي بالإيهام واللغلط بمتابعة غيره له ، لاحتمال أن يكون الثيخ قد روى الحديث مرة على لفظ الزيادة، ومرة بدونها، فرواه بعضهم عنه بالزيادة، ورواه الآخرون بدونها ، فتخرج الزيادة

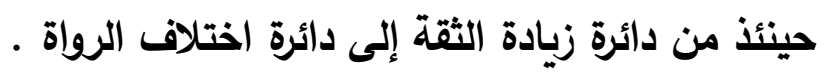
قال الاكتور أبو ذر عبد القادر: فأما إذا كان أكثر من واحد كأن يتابع ذلك الثقة بثقة آخر، أو ممن يعتبر به في المتابعة، خرج عن 
أن يكون هذا الحديث من قبيل زيادة الثقة، وإنما هو من قبيل المختف، لاحتمال أن يكون الثيخ رواه على الوجهين، فحمله كل

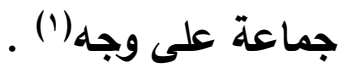
وقال أيضا: أما إذا وجلنا متابعة لهذا الثقة فإنه يخرج من دائرة الزيادة والتفرد إلى دائرة الاختلاف ... "مختلف الحديث"، فندرس الحديثين ونخرج بنتيجة حسب القرائن المرجحة. أيّ أنّ زيادة الثقة إنما تكون من ثقة واحد أمام جماعة، أما إذا تكافأ العدد كأن يكون واحداً أمام واحد فهذه لا تسمى زيادة ثقة، بل هي من باب:"مختلف الحديث" لذا فإن الإمام النووي رحمه الله وهو القائل بقبول الزيادة مطلقاً من غير تفصيل رد التمثيل بزيادة مالك "من المسلمين"، وقال:" لا يصح التمثيل به فقد وافق مالكاً عمر بن نافع، والضحاك

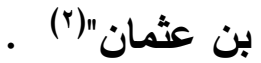
قلت: تفصيل ذلك أن قوله"من المسلمين" في حديث زكاة الفطر، لم يتفرد بها مالك عن نافع · بل تابعه فيها كلا من الضحاك ، وعمر

(ا) الثاذ والمنكر وزيادة الثقة - موازنة بين المتقدمين والمتأخرين لأبي ذر عبد القادر بن مصطفى بن عبد الرزاق المحمدي ط: دار الكتب العلمية، بيروت - لبنان ، الطبعة:

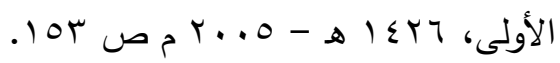

(r) الثاذ والمنكر وزيادة الثقة - موازنة بين المتقدمين والمتأخرين ص ه هـ 17 ، ، وانظر

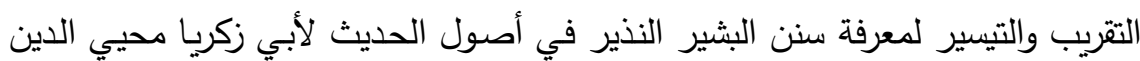
يحيى بن شرف النووي (المتوفى: TVIهـ)، تقديم وتحقيق وتعليق: محمد عثمان الخشت،

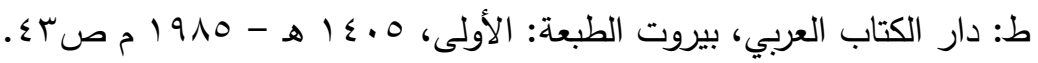


بن نافع عن أبيه، فأخرجها مسلم في صحيحه(')من طريق الضَّحَّاكُ،

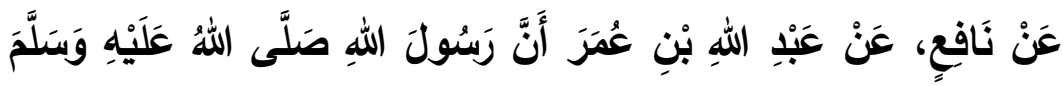

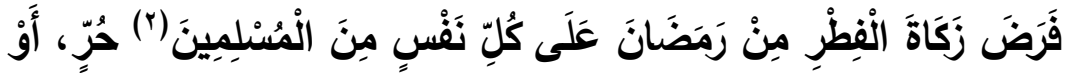

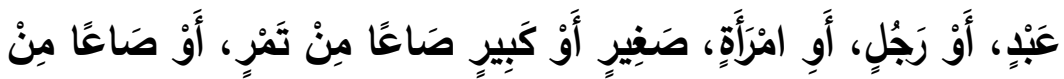

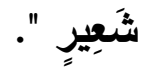

وكذلك أخرجها البخاري في صحيحه(َ)بإِناده من طريق عُعَرَ بْنِ

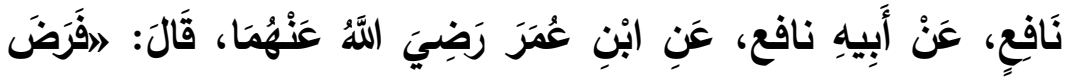

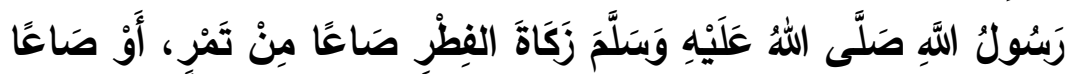

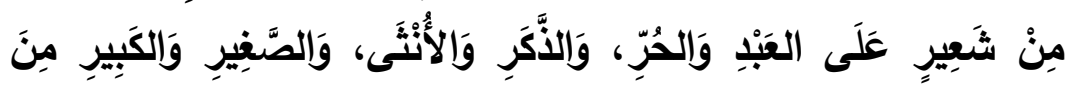

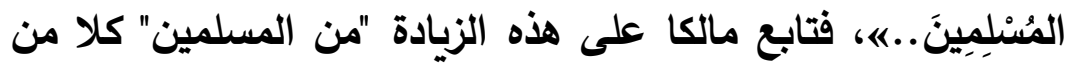
الضحاك ، وعمر بن نافع، فلا يصح هذا المثال كتطبيق لزيادة الثقة، لأن زيادة الثقة تكون مع تفرد الراوي بالزيادة دون متابع.

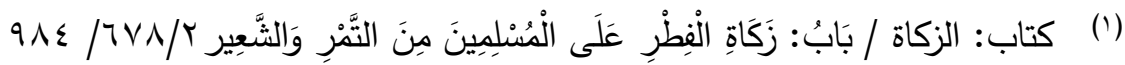

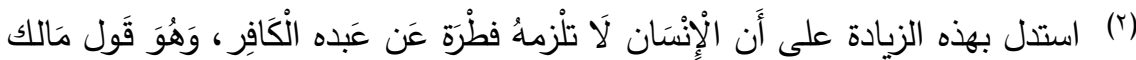

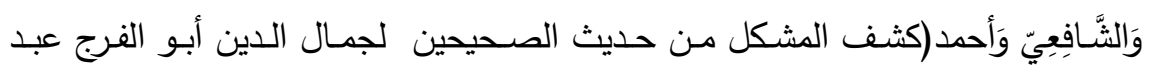

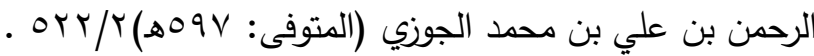

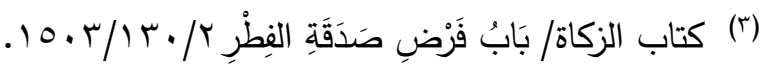

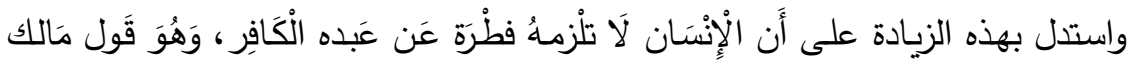

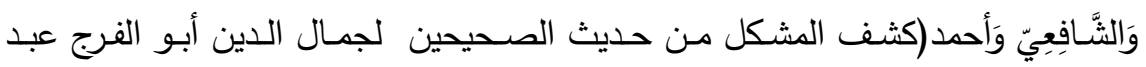

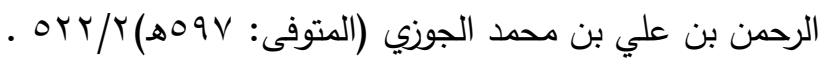


وقد روي عن الإمام أحمد تهيبه من زيادة الإمام مالك في حديث

صدقة الفطر بزيادته لفظ "من المسلمين" حتى وجد لله متابعا(1)

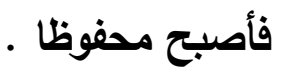

قال ابن رجب: قد قال أحمد في رواية عنه: كنت أتهيب حديث مالك "من المسلمين" يعني حتى وجده من حديث (العمريين) قيل لله: أمحفوظ هو عندك "من المسلمين"؟ قال: نعم. وهذه الرواية تدل على هي توقفه في زيادة (واحد من الثقات) ، ولو كان مثل مالك، حتى يتابع على تلك الزيادة، وتدل على أن متابعة مثل العمري(؟) لمالك مما يقوي رواية مالك، ويزيل عن حديثه الثذوذ والإنكار (). r-أن تكون هذه الزيادة مع اتحاد مخرج الحديث: بأن يكون حديثا واحدا عن صحابي واحد وروي في واقعة وحادثة واحدة فيرويه الثقات ناقصا

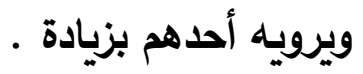

قال ابن التركماني: "إنما تعلل رواية برواية إذا ظهر اتحاد الحديث"(؛) .

$$
\text { حيث تابعه عمر بن نافع ، والضحاك بن مزاحم ، كما مر بيانه. }
$$

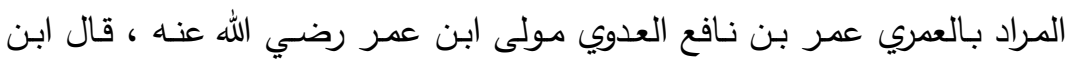

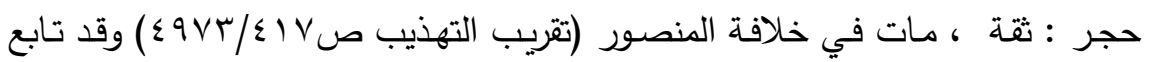

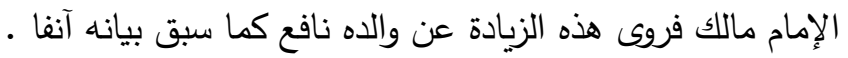

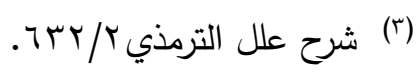

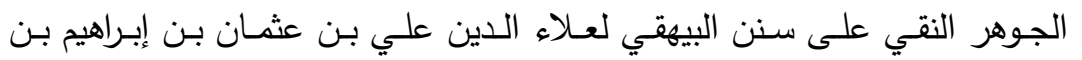

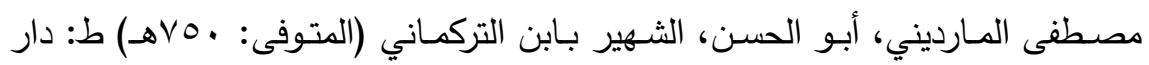
الفكر ص^マr. 
قلت: أما إن اختلف المخرج بأن تعددت طرق الحديث عن صحابيين أو أكثر فتكون الزيادة حينئ بمثابة حديث مستقل روى عن صحابي آخر، فزيادات الصحابة بعضهم على بعض لا علاقة لها بمعنى زيادة الثقة. قال الحافظ ابن حجر: إن الأي يبحث فيه أهل الحديث في هذه المسألة إنما هو في زيادة بعض الرواة التابعين فمن بعدهم، وأما الزيادة الحاصلة من بعض الصحابة على صحابي آخر إذا صح السند إليه فلا يختلفون

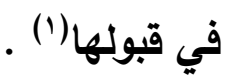

قلت أي أن زيادة الثقة تكون فيما دون الصحابي، أي زيادة التابعين

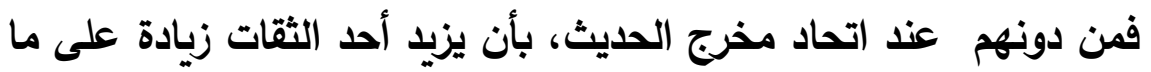
رواه الآخرون عن شيخ لهم عن نفس الصحابي ، أما إن اختلف المخرج فرُوِي الحديث عن صحابين مختلفين فليس ذلك من قبيل زيادة الثقة، وإنما هما حديثين مستقلين ، وأحيانا يكونان من باب المطلق والمقيا . قال ابن رجب: فإذا روي حديثان مستقلان في حادثة، وفي أحدهما زيادة فإنها تقبل من الثقة، كما لو انفرد الثقة بأصل الحديث. وليس هذا من باب زبادة الثقة (ولا سيما إذا كان الحديثان موقوفين عن صحابيين) ، وإنما قد يكون أحياناً من باب المطلق والمقيد (r). وفد مثل الحافظ ابن حجر(r) لزيادات الصحابة بعضهم على بعض بحديث

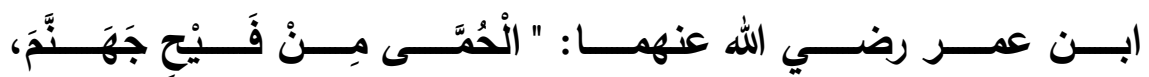

(1) (1) النكت على كتاب ابن الصلاح / (19) 79

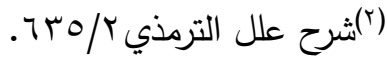

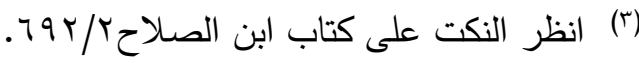




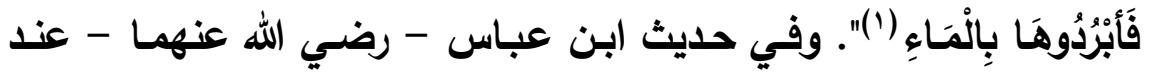

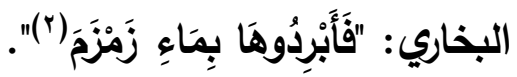
فمثل هذه الزيادة مقبولة لاختلاف مخرج الحديث . قال العلائي: "إذا اختلفت مخارج الحديث، وتباعدت ألفاظه، فالذي ينبغي

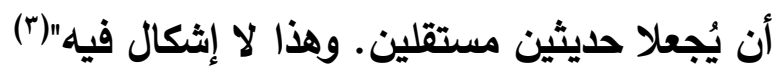
وقال الحافظ ابن حجر: "إذا اختلفت مخارج الحديث، وتباعدت ألفاظه، أو كان سياق الحديث في حكاية واقعة يظهر تعددها، فالذي يتعين القول به أن يُجعلا حديثين مستقلين (؛) وقال ابن رجب في معرض بيانه لتعليل الأئمة حديثاً بآخر : "واعلم أن هذا كله إذا علم أن الحديث الذي اختلف في إسناده حديث واحد، فإن ظهر أنها

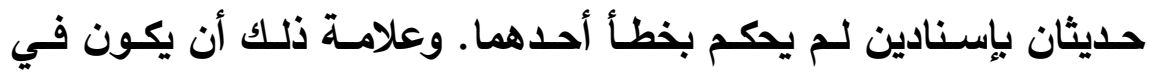
أحدهما زيـادة على الآخر أو نقص منـه، أو تغيـر يستـل بـه على أنـه

(') متفق عليه ، أخرجه البخاري في صحيحهء كتاب بدء الخلق : باب: بَابُ صِفَةِ

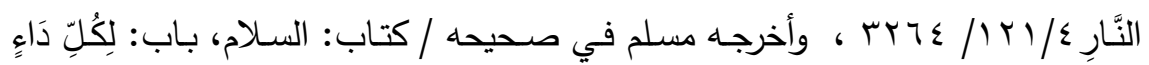

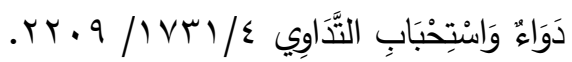

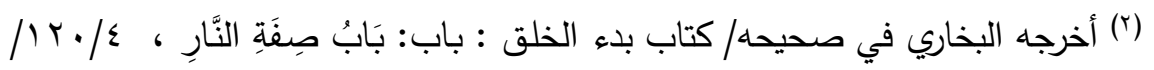

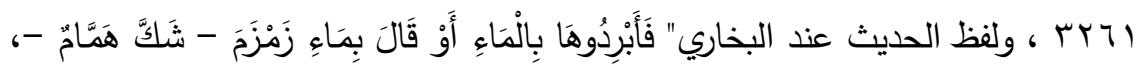

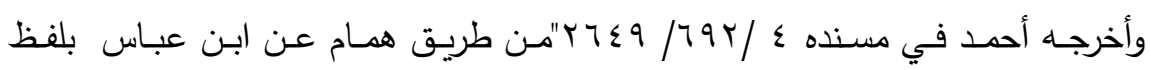

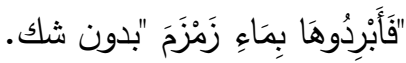

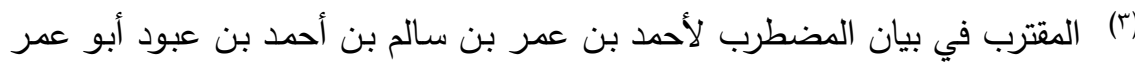
بازمول السلفي المكي الرحابي

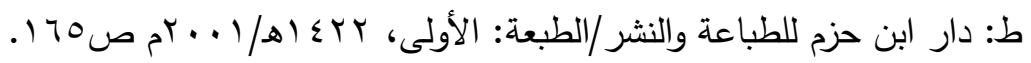

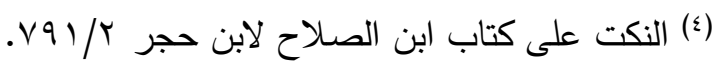


حديث آخر . فهذا يقول علي بن المديني وغيره من أئمـة الصنعة: همـا

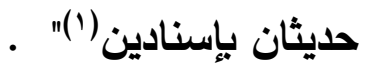
ـ - ألا تكـون هـذه الزبـادة مدرجـة (r)، فـإذا تبـين إدراجهـا مـن الـراوي وإقحامها على أصل الحديث خرجت عن كونها زيـادة ثقة، لأن هذه الزيادة المدرجة ليست من الحديث أصلا، ولم يزدها أحد الثقات فيما يرويـه من أصل الحديث، وإنما هي من كلام أحد الرواة.

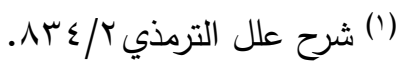
(r) الحديث المدرج: ما كان فيه زيادة ليست منه في الإسناد أو المتون. ومدرج المتن:هو

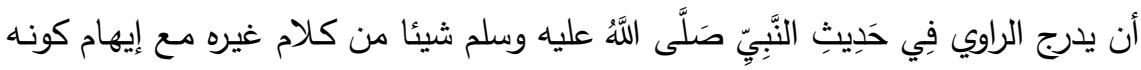

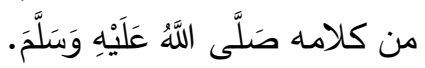
ويعرف الإدراج في الحديث بأحد ثلاثة أمورثلاثة هي: الأول: أن يكون في الحديث كلام يستحيل إضافته إلى النبي صلى اللى الله عليه وسلم.

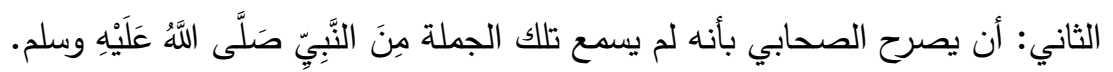

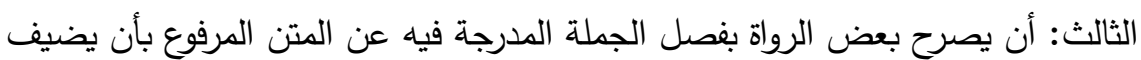

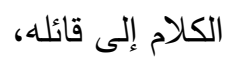
قال السخاوي: " أو باقتصار بعض الرواة على الأصل المرفوع.

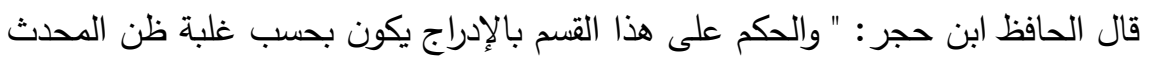
الحافظ الناقد ولا يوجب القطع بذلك بخلاف القسمين الأولين.وأكثر هذا الثالث يقع تفسيرا

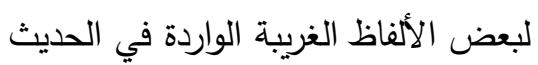
(الفصل للوصل المدرج في النقل للخطيب البغدادي (المتوفى: بآـهـ) تحقيق: محمد لوند

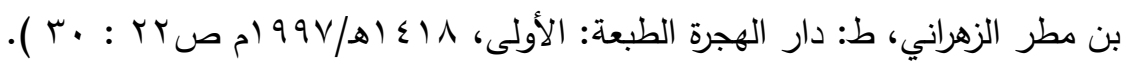




\section{المبحث الثاني}

\section{العلاقة بين زيادة الثقة وبين غيرها من أنواع علوم الحديث}

إن زيادة الثقة ليست مبحثا مستقلا بذاته ، بل هو منفتح ومتداخل مع غيره من أنواع علوم الحديث ذات الصلة الوثيقة به كالحديث المعلول بتعارض الوصل والإرسال أوالرفع والوقف، وكالحديث الثاذ ، والمزيد في متصل الأسانيد، وقد حاولت في هذا البحث إظهار الترابط بين هذه العلوم وعرضها بوحدة موضوعية حتى يمكن الوصول إلى نتيجة صحيحة غير متناقضة في الحكم على هذه الأنواع. أولا: العلاقة بين زيادة الثقة والحديث المعلول بتعارض الوصل والإرسال أو الرفع والوقف:

لا شك أن زيادة الوصل على الإرسال وزيادة الرفع على الوقف هي نوع من أنواع زيادة الثقة إذا كان الواصل والرافع ثقة من الثقات، وقد أثار ابن الصلاح إلى ذلك في كلامه على تعارض الرفع والوقف.

يقول ابن الصلاح: إذا رفع بعضهم الحديث إلى النبي صلى الله عليه وسلم ووقفه بعضهم على الصحابي. أو رفعه واحد في وقت ووقفه هو أيضا في وقت آخر. فالحكم على الأصح في كل ذلك لما زاده الثقة من الوصل والرفع لأنه مثبت وغيره ساكت، ولو كان نافيا فالمثبت مقدم عليه، لأنه علم ما خفي عليه. ولهذا الفصل تعلق بفصل زيادة الثقة في الحديث

وسيأتي إن شاء الله تعالى وهو أعلم (') 
كما أشار العراقي إلى ذلك في ألفيته فقال:(والوصل والإرسـال من ذا أخذ)

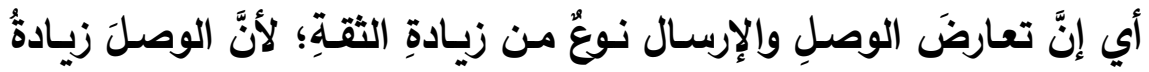
ثقةٍة (').

وقد نكَّت الحافظ ابن حجر على ابن الصلاح لإيراده مبحث تعارض الوصل

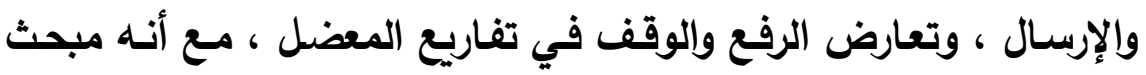
مستقل، وكان يرى أن الأليق به إيراده في تفاريع المعلل بتعارض الوصل والإرسـال أو الرفع والوقفف ، أو إيـراده في زيـادة الثقـة كمـا أثـار ابـن الصلاح نفسه إلى ذلك.

فقال ابن حجر: مـا أدري مـا وجـه إيراد هذا في تفاريع المعضل. بـل هذا قسم مستقل وهو: تعارض الإرسال والاتصال والرفع والوقف. نعم، لو ذكره في تفاريع الحديث المعلل، لكان حسنا ، وإلا فمحل الكـلام فيه في زيـادة الثقات كما أشار إليه(ب) الثاليه وقال الإمام السخاوي في مستهل كلامسه عن زيـادة الثقة: هو فن لطيف تستحسن العنايـة بـه، يعرف بجمـع الطرق والأبـواب، ومناسبته لمـا قبلـه ظـاهرة، ولكـن كـان الأنسـب - كمـا قدمنا - ذكره مـع تعـارض الوصل والإرسال (r) (1)

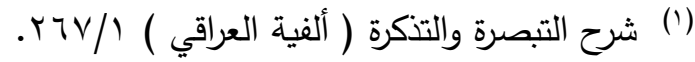

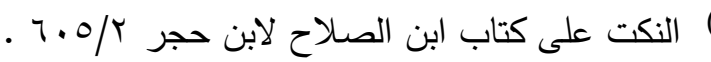

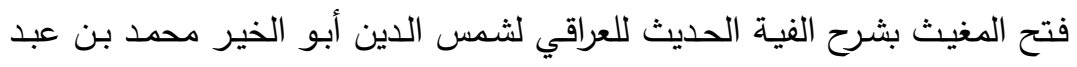

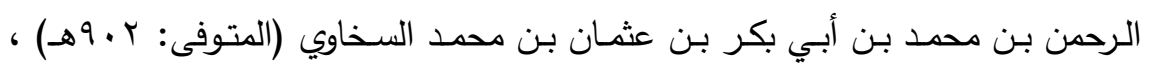

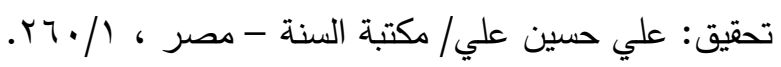


وقال الاكتور همام عبد الرحيم سعيد في تحقيقه لشرح علل الترمذي: جدير بالذكر أن الصلة وثيقـة بين علم العلل وبين هذا الفن من فنون الحديث، وكثيرا ما يجد الباحث في كتب العلل تطبيقات لزيادة الثقة، وأمسام كل زيادة من هذه الزيادات تختلف الأنظار، وذلك حسب موافقة الزيـادة أو مخالفتهـا للأصـل المزيـــ عليـه، وحسـن مكانـة الـراوي الــي جـاء بهذه الزيادة (1) إذًا فالخلاف في مسألة تعارض الوصل والإرسال كالخلاف في زيادة الثقة، وهو ما جزم به ابن كثير عن ابن الصلاح. قال ابن كثير: وذكر_ أي ابن الصلاح- أن الخلاف في الوصل والإرسـال، كالخلاف في قبول زيادة الثقة(؟). وقال ابن حجر: جزم ابن الحاجب أن الكل بمعنى واحد، فقال: "وإذا أسند

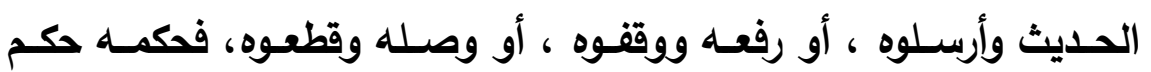
الزيادة على التفصيل السابق(זّ). وقد استنكر الحافظ ابن حجر وجود أي تغاير أوفرق بين مسألة تعارض الوصل والإرسال ومسألة زيادة الثقة ، فاعترض ابن حجر على من يقدم الإرسال على الوصل عند التعارض، ثم يقول بقبول زيادة الثقة ـ

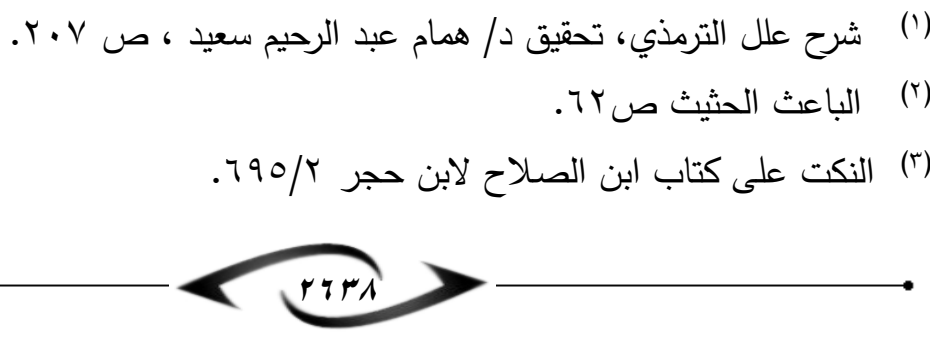


يقول ابن حجر: حكى ابن الصلاح عن الخطيب فيما إذا تعارض الوصل والإرسال أن الأكثر من أهل الدديث يرون أن الحكم لمن أرسل (1)، وحكى الصى

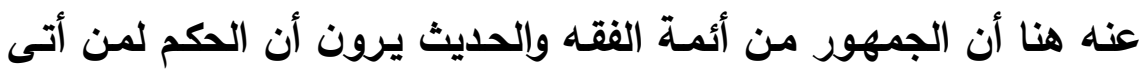
بالزيادة إذا كان ثقة ـ وهذا ظاهره التعارض ومن أبدى فرقا بين المسألتين

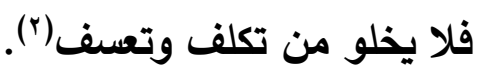

ثم اعتذر ابن حجر عن الخطيب فقال: يمكن الجواب عن الخطيب، بأنها

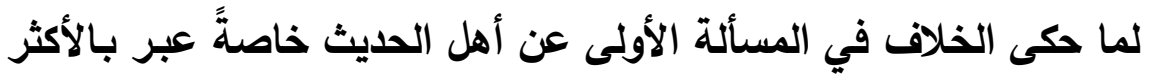

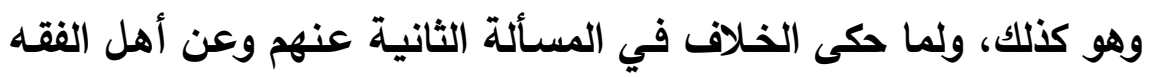

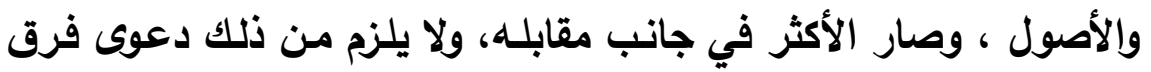

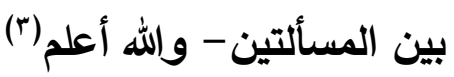
أي أن ما حكاه الخطيب في مسأكة تعارض الوصل والإرسال إنما هو قول

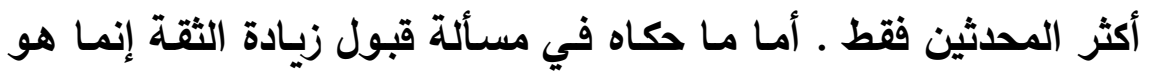

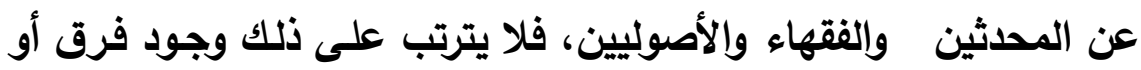

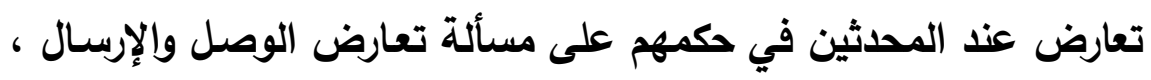
ومسألة زيادة الثقة .

ولهذا نجد اختلاف المحدثين في حكم تعارض الوصل والإرسال شبيها

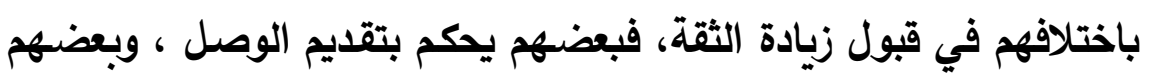

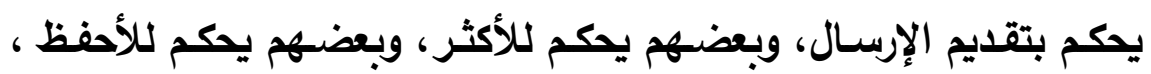

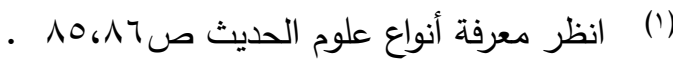

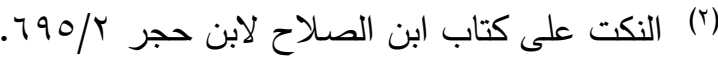

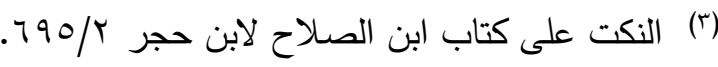


ومنهم من يرى أنه ليس لأئمة الحديث في هذا قانون مطرد، بل عملهم في ذلك دائر مـع الترجيح(')، وهذا هو عين اختلافهم في قبول زيـادة الثقة، على تفصيل سيأتي بيانه في حكم الزيادة.

\section{ثانيا: العلاقة بين زيادة الثقة والحديث الشاذ:}

من شـروط قبـول الحـيث سـلامته من الثـذوذ والعلـة، فقد يصـح إسـناد الحديث ولا يصح متنه إذا كان المتن شاذا . يقول ابن الصلاح: " قد يقال: هذا حديث صحيح الإسناد ولا يصح، لكونه

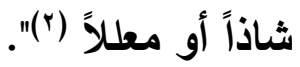

ولبيـان العلاقة بين زيـادة الثقـة والحديث الثـاذ، فلابــ مـن بيـان المعنى الإصطلاحي للحديث الثاذ، وق اختلف المحدثون في بيان ماهية الثـاذ، فأطلقـه بعضهم على مطلق التفرد سـواء كان المتفرد ثقـة أو غير ثقـة، مخالفـا أو غير مخـالف، وقد اعتُرض على ذلك(ب)، واستقر الأمـر على تعريف الإمام الشافعي للشاذ، وهو ما اعتمده الحفاظ .

(') انظر النكت على كتاب ابن الصـلاح لابن حجر / / . 1 بتصـرف ، والكرأي

$$
\begin{aligned}
& \text { الأخير حكاه ابن حجر عن ابن دقيق العيد والعلائي. } \\
& \text { معرفة أنواع علوم الحديث صـمبـ. }
\end{aligned}
$$

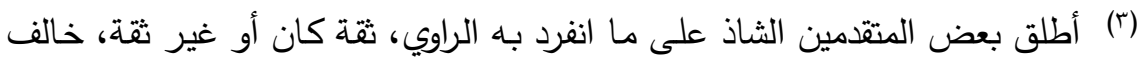

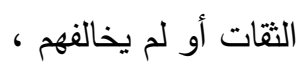

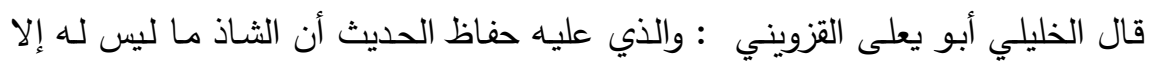

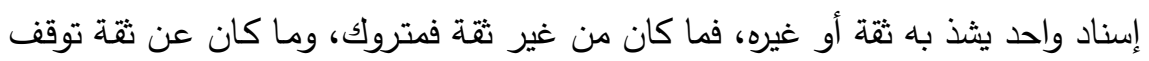

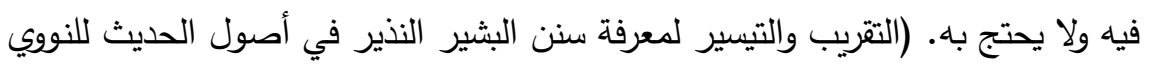

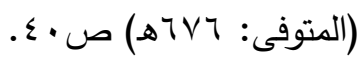
$==$ 
قال الشافعي : " ليس الثاذ من الحديث أن يروي الثقة ما لا يروي غيره، إنما الثاذ أن يروي الثقة حديثا يخالف ما روى الناس (1)".

وقـال الشـافعي أيضـا وجماعـة مـن أهل الحجـاز : الثـاذ عنـنـا مـا يرويـهـ الثقات على لفظ واحد ويرويـه ثقة خلافه زائدا أو ناقصا(؟) .

وقال الحاكم : "الثاذ هو الحديث الذي يتفرد به ثقة من الثقات، وليس له أصل بمتابع

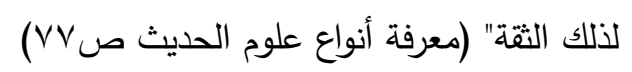

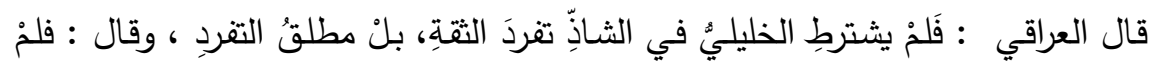

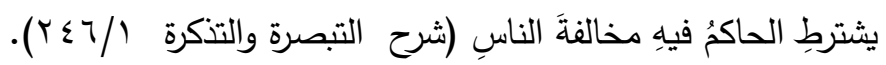

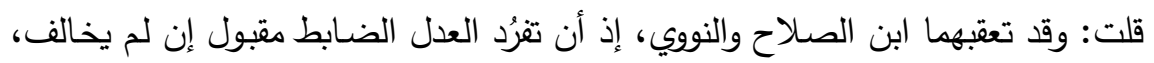

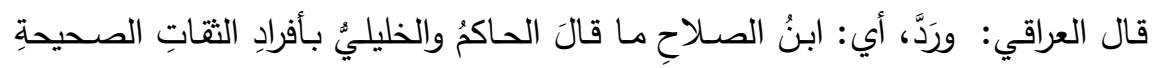

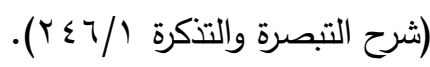

وقال النووي : وما ذكراه مشكل بأفراد العدل الضـابط كحديث " إنما الأعمال بالنيات " والنهي عن بيع الولاء وغير ذلك مما في الصحيح، فالصحيح التفصيل ، فإن كان مفرده

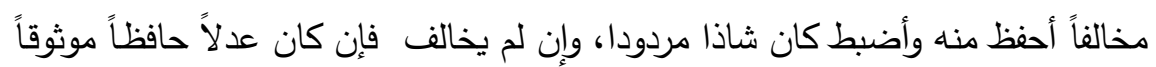
بضبطه كان مفرده صحيحاً، وإن لم يوثق بضبطه ولم يبعد عن درجة الضـابط كان مدان

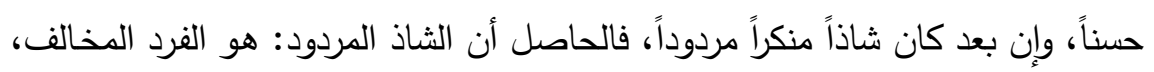

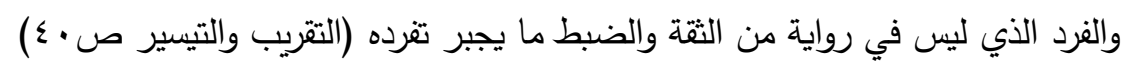

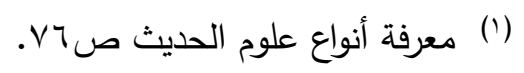

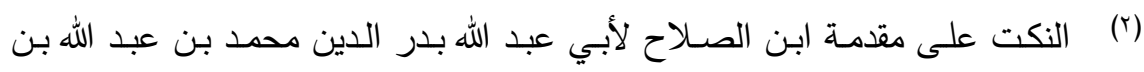

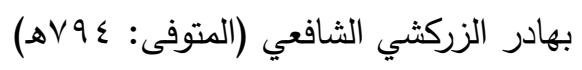

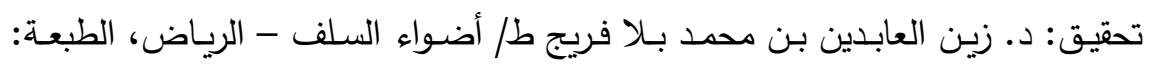

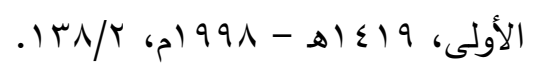


وقد وافق الشافعي جمهور من المحدثين وعلى رأسهم الحافظ ابن حجر، والنووي والسخاوي وغيرهم.

قال النـووي: ومـذهب الثـافعي وطائفـة مـن علمـاء الحجـاز أن الثـاذ مـا يخالف الثقات، أمسا مـالا يخـالفهم فليس بثـاذ، بـل يحتج بـه، وهذا هـو (الصحيح. (1)

وقال السخاوي: فالأليق في حد الشاذ ما عرفه به الشافعي(؟).

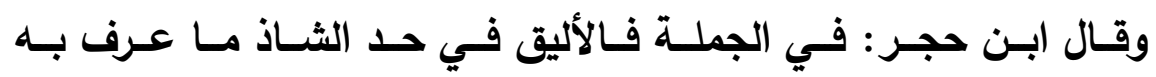

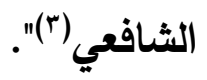

واتفق تعريـف ابن حجر للثـاذ مـع تعريـف الثـافعي ، فقال ابن حجر :

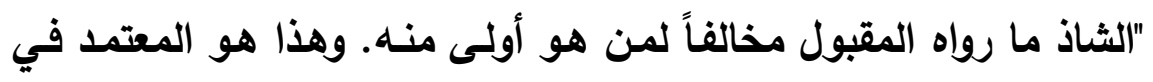
تعريف الثاذ بحسب الاصطلاح (؛) قلت: من هنـا تتضـح العلاقة بين الثـاذ وزيـادة الثقة ، فإذا كانت هذه

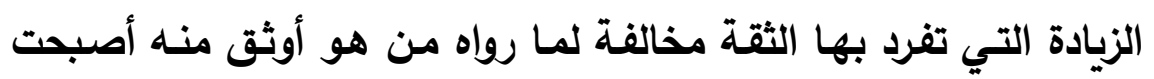

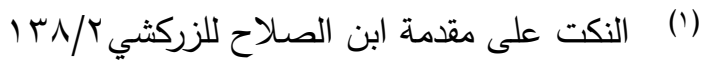

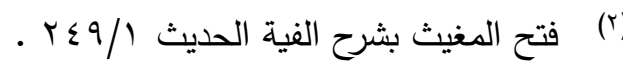

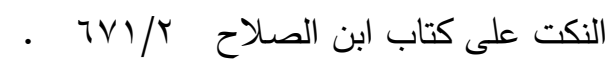

(؛) نزهة النظر في توضيح نخبة الفكر في مصطلح أهل الأثر نزهة النظر في توضيح نخبة الفكر في مصطلح أهل الأثر لأبي الفضل أحمد بن علي بن محمد بن أحمد بن حجر العسقلاني (المتوفى: بلوهـهـ

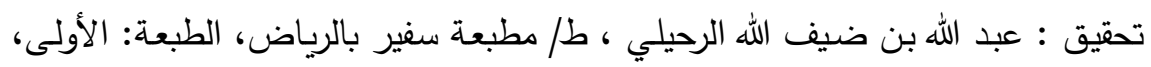

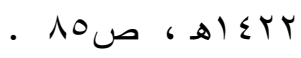


هذه الزيادة رواية شاذة، فبين الثاذ وزيادة الثقة عموم وخصوص وجهي،

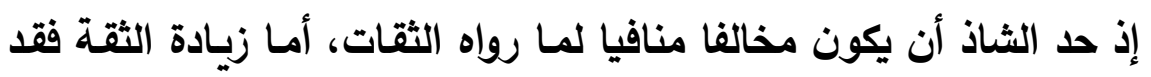

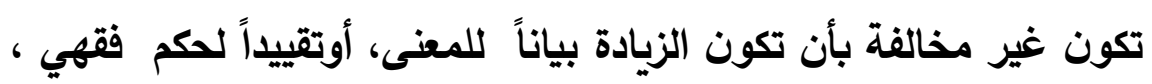

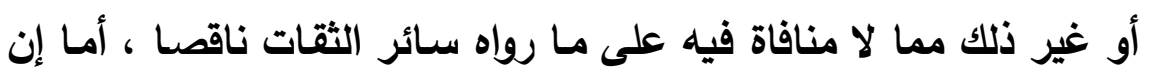
كانت الزيادة مخالفة لمن هم أوثق وأحفظ فهي روايـة شـاذة، ولهذا حكم أكثر المحثثين برد الزيادة المخالفة لرواية الثقات لثذوذها ، على تفصيل سيأتي بيانه في حكم زيادة الثقة . وعلى هذا يكون الثـاذ أحد أقسام زيـادة الثقة ، وهو مـا وافق كلام ابن الصلاح عند تقسيمه لأنواع تفرد الثقة ، يقول ابن الصلاح: وقد أيت تقسيم ما ينفرد به الثقة إلى ثلاثة أقسام: أحدها: أن يقع مخالفا منافيا لما رواه سـائر الثقات، فهذا حكمـه الرد كمـا سبق في نوع الشاذ. الثاني: أن لا تكون فيـه منافـاة ومخالفـة أصـلا لمـا رواه غيره، كالحديث الذي تفرد برواية جملته ثقة، ولا تعرض فيه لما رواه الغير بمخالفة أصلا، فهذا مقبول، وقد ادعى الخطيب فيه اتفاق العلماء عليه ، ... الثالث: ما يقع بين هاتين المرتبتين مثل زيادة لفظة في حديث لم يذكرها سائر من روى ذلك الحديث(').

وقال أيضا : إذا انفرد الراوي بشيء نظر فيه فإن كان ما انفرد بـه مخالفاً لما رواه من هو أولى منه بالحفظ لذلك وأضبط، كان مـا انفرد بـه شـاذاً 
مردوداً، وإن لم يكن فيه مخالفة لما رواه غيره وإنما هو أمر رواه هو ولم يروه غيره فينظر في هذا الراوي المنفرد فيان كـان عدلاً حافظاً موثوقاً بإتقانه وضبطه قبل مـا انفرد بـه، ولم يقدح الانفراد فيه، كمـا سبق من الأمثلة، وإن لم يكن ممن يوثق بحفظه وإتقانـه لذلك الذي انفرد بـه، كان انفراده به خارماً له مزحزحا له عن حيز الصحيح ، ثم هو بعد ذلك دائر بين مراتب متفاوتة بحسب الحال فيه، فإن كان المنفرد بـه غير بعيد من درجة الضـابط المقبول تفرده استحسنا حديثه ذلك، ولـم نحطه إلى قبيل الحديث الضعيف، وإن كان بعيداً من ذلك رددنا ما انفرد به وكان من قبيل الثاذ المنكر(")، فخرج من ذلك أن الثاذ المردود قسمان: أحدهما الحديث

(1) المعتمد في تعريف الثـاذ اصطلاحا كما بينا هو مَا رَوَاهُ المقبول مُخَالفا لمن هُوَ

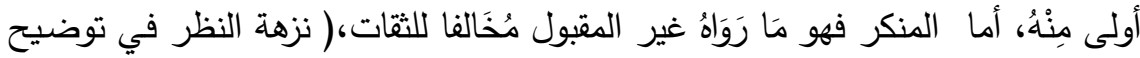

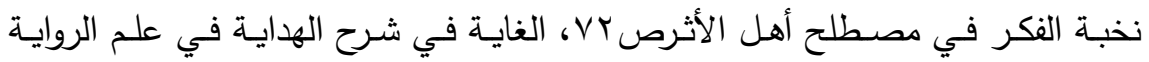

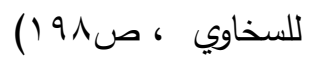

قلت: ولم يميز ابن الصـلاح في كلامهه بين الثـاذ والهنكر ، وجعلهما مترادفين ، وقد

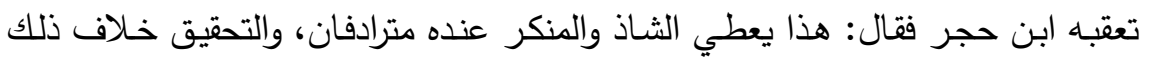
(النكت (TV/r) وقال ابن حجر : نعم هما مشتركان في كون كل منهما على قسمين، وإنما اختلافهما في

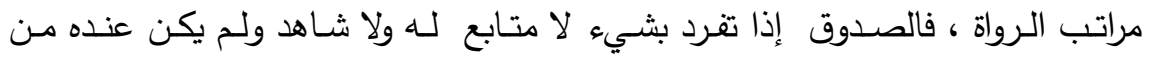

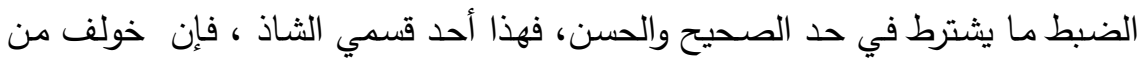

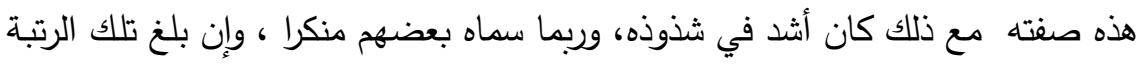
في الضبط، لكنه خالف من هو أرجح منه في الثقة والضبط، فهذا القسم الثاني من الثاذ

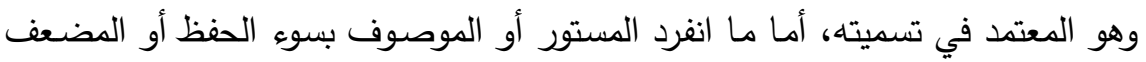

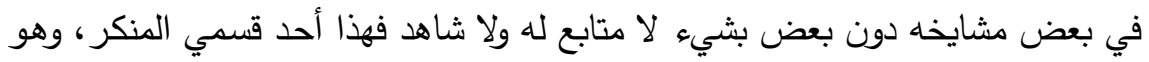

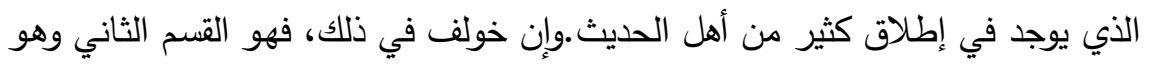
$==$ 
الفرد المخالف، والثاني الفرد الذي ليس في راويـه من الثقـة والضبط مـا

يقع جابراً لما يوجبه التفرد والثذوذ من النكارة والضعف، والله أعلم (1) وعلى هذا فزيادة الثقة إن كانت منافية لمـا رواه الثقات فإنها رواية شاذة مردودة ، فالثاذ أحد أقسـام زيـادة الثقـة ، ولهذا اعترض ابن حجر على معلى من قال بقبول زيادة الثقة مطلقا، إذ يتنافى ذلك مع ما قره المحدثون من رد الرواية الثاذة التي تخالف ما رواه الثقات. يقول ابـن حجر: "اشـتهر عن جمع مـن العلمـاء القـول بقبـول الزيـادة

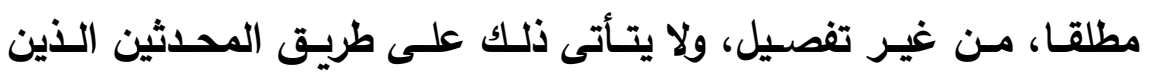
يشترطون في الصحيح أن لا يكون شـاذا، ثم يفسرون الشـوذ بمخالفـة

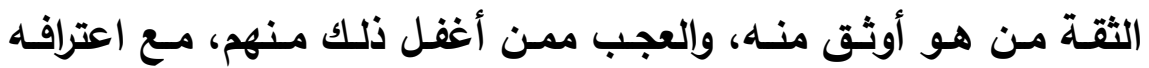
باشتراط انتفاء الثذوذ في حد الحديث الصحيح، وكذا الحسن(). وقال أيضا: هنا شيء يتعين التبييه عليه وهو: أنهم شرطوا في الصحيح أن لا يكون شاذا، وفسروا الثاذ بأنه ما رواه الثقة فخالفه من هو أضبط منه أو أكثر عددا، ثم قالوا: تقبل الزيادة من الثقة مطلقا، وبنوا على ذلك

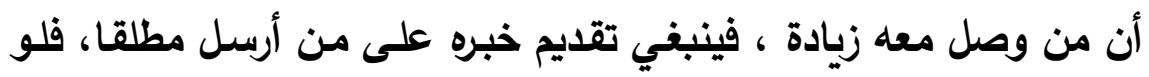
اتفق أن يكون من أرسل أكثر عددا أو أضبط حفظا أو كتابـا على مـن

المعتمد على رأي الأكثرين. فبان بهذا فصل المنكر من الثـاذ وأن كلا منهما قسمان

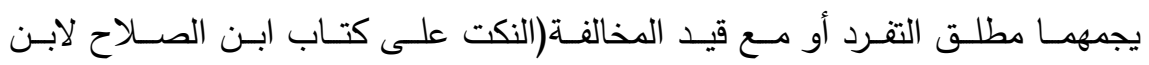

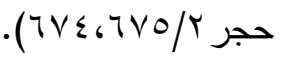

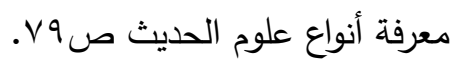

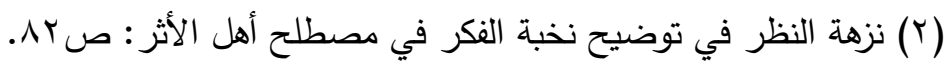


وصل أيقبلونه أم لا؟ أم هل يسمونه شاذا أم لا؟ لا بـ من الإتيان بالفرق

أو الاعتراف بالتناقض( ')

مـن هنـا يتبين الترابط الوثيق بين تعـارض الوصسل والإرسـال، والثـاذ ، وزيادة الثقة

وضرورة عرض هذه الموضوعات الحديثية في وحدة موضوعية يضمها حكم كلي منعـا للتنـاقض والتعـارض فـى الحكم عليها ، وسـيأتي الكـلام تفصيلا عن حكم زيـادة الثقـة في موضـعه مـن هذا البحث إن شـاء الله تعالى.

\section{ثالثا: العلاقة بين زيادة الثقة والمزيد في متصل الأسانيد:}

والمزيــ في متصل الأسـانيد كما قال ابن كثير : هو أن يزيــ في الإسناد

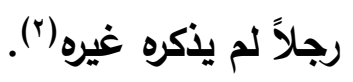

قلت: ويكون الإسناد الخالي من هذه الزيادة ظاهره الإتصال . فإن ثبت أن الإسناد الخالي من الزيادة متصـلا ، كـان الإسناد المزيــ فيه رجلا من قبيل المزيد في متصل الأسانيد ، وهذا الإسناد المزيــ ربمـا يكون متصلا أيضا كأن يكون راويـه سمع الحديث بواسطة عن شيخه فزاد هذا

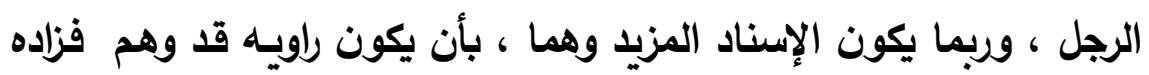

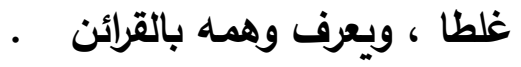

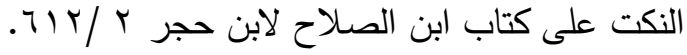

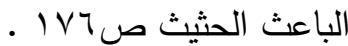


وقد اشترط المحدثون أن يُصرَح بالسماع في الإسناد الخالي من الزيادة ، حتى يحكم لله بالإتصال ، ويكون الإسناد الزائد من باب المزيد في متصل الإسناد، أما إن لم يثبت الإتصال بين الراوي وشيخه في موضع الزيادة كأن يكون الإسناد الخالي من الزيادة معنعنا عن شيخه، فإنها يحمل على الإنقطاع، وتكون الزيادة حينئذ طريق متصل ، وبـخل الإسناد الخالي من الزيادة تحت المعلول بالإنقطاع ، ولا ياخل الإسناد الزائد في باب المزيل في متصل الأسانيا.

قال ابن حجر: وشرطه أن يقع التصريح بالسماع في موضع الزيادة، وإلا فمتى كان معنعنا، مثلا، ترجحت الزيادة (1) . وقال ابن الصلاح: لأن الإسناد الخالي عن الراوي الزائد، إن كان بلفظة (عن) في ذلك فينبغي أن يحكم بإرساله، ويجعل معللا بالإسناد الذي ذكر الإن فيه الزائد،

وإن كان فيه تصريح بالسماع أو بالإخبار كما في المثال الذي أوردناه(؟)، فجائز أن يكون قد سمع ذلك من رجل عنه، ثم سمعه منه نفسه ...اللهح إلا أن توجد قرينة تدل على كونه وهما(ّات.

قلت: أي أن الـراوي ربمـا سـمع الحديث بواسـة عـن شـيخه فزراد هـذه الواسـة في الإسـناد ، ثم نشط فسمعه عاليا مـن شـيخه مباشـرة بـلا واسطه فرواه مرة أخرى خاليا من هذه الزيـادة ، إلا إن وجدت قرائن تدل

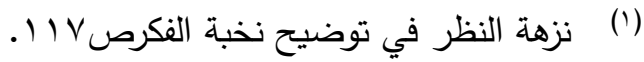

سيأتي ذكره في الفقرة التالية.

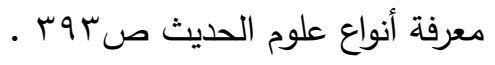


على إيهام الراوي في هذه الزيادة كأن يكون من لم يزدها أتقن ممن زادها فحينئذ تكون الزيادة مرجوحة. قلت: وقد مثَّل لـه ابن الصـلاح بمـا روي عن عبد الله بن المبارك، قال: حدثنا سفيان، عن عبد الرحمن بن يزيـا بن جابر، قال: حدثني بُنْرِ بْنِ عُبَيْد اللهِ، قال سمعت أبا إدربس، يقول: سمعت وإثلـة بن الأسقع، يقول:

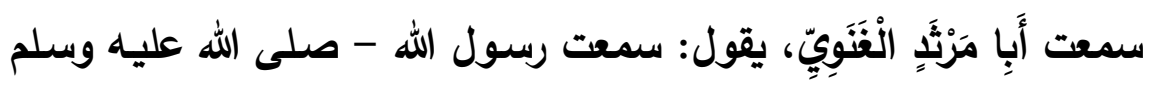

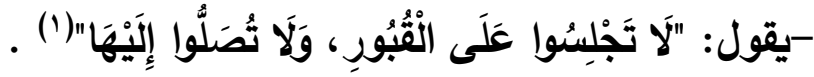
قال ابن الصلاح: فِّكُر سـفيان في هذا الإسناد زيـادة ووهم ، وهكذا ذِكرُ أبي إدريس: أمسا الوهم في ذكر سـفيان فممن دون ابن المبارك لأن جماعة ثقات رووه عن ابن المبارك عن ابن جابر نفسه، ومنهم من صرح فيه بلفظ الإخبار بينهما. وأما ذكر أبي إدربس فيه فابن المبارك منسوب فيـه إلىى الوهم؛ وذلك لأن جماعـة مسن الثقات رووه عن ابـن جابر فلم

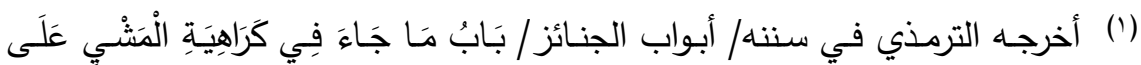

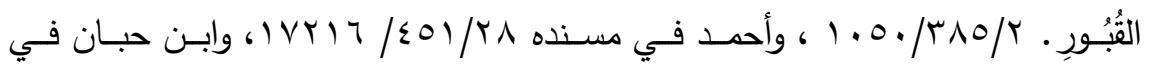

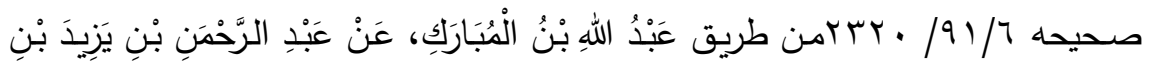

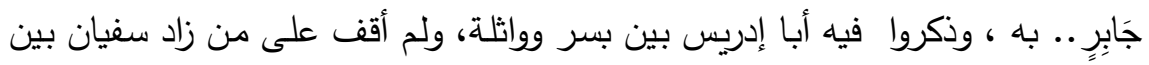

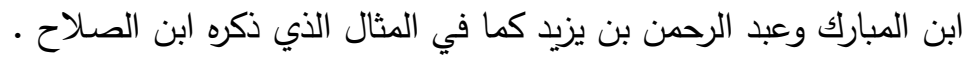

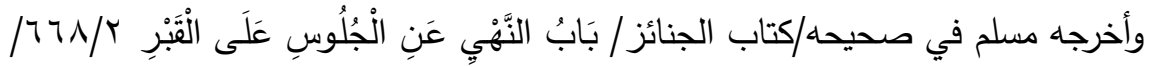

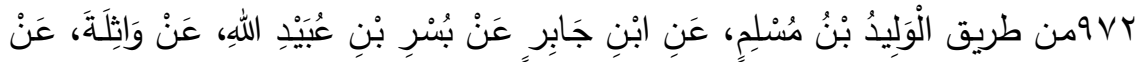

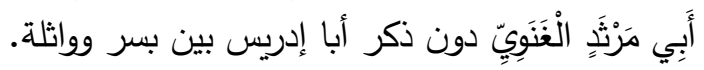

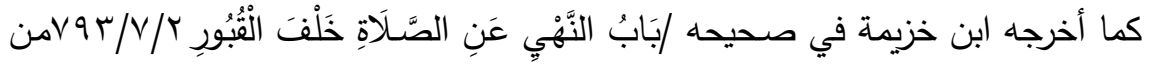

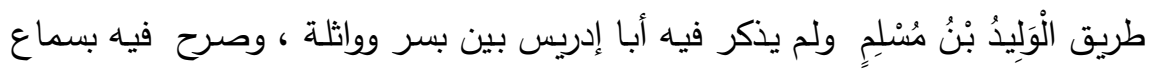
بسر من واثلة . 
يذكروا أبا إدريس بين بُسر وواثِلة. وفيهم من صرح فيه بسماع بُسر من واثلة (')

قال أبو حاتم الرازي: يرون أن ابن المبارك وهم في هذا ، قال: وكثيرا مـا

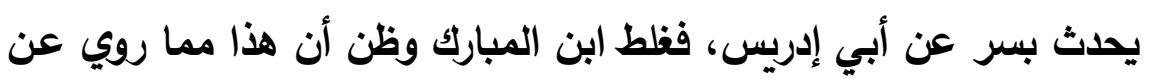

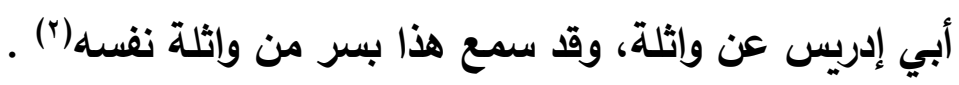

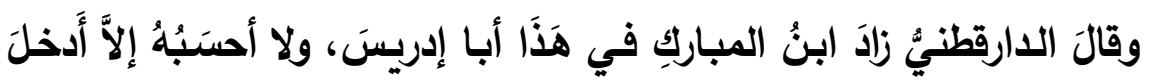

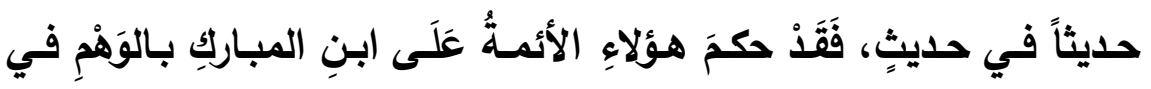

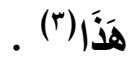

قال ابن الصلاح: فيكون بسر في هذا الحديث قد سمعه من أبي إدريس

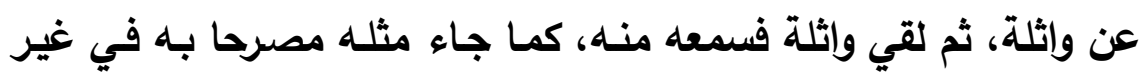

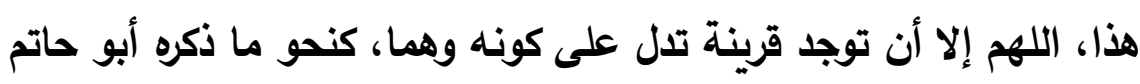

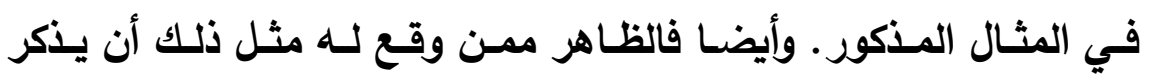

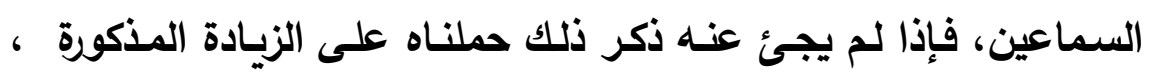

والله أعلم (₹)

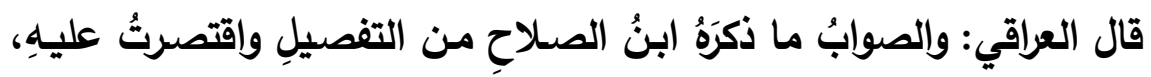

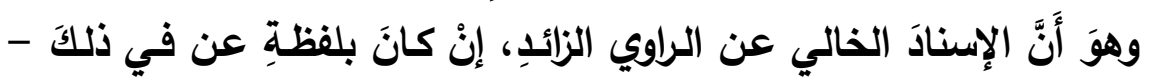

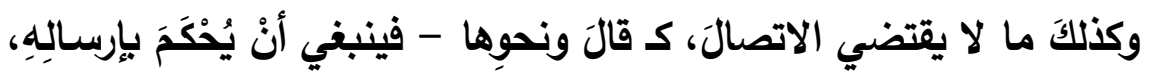

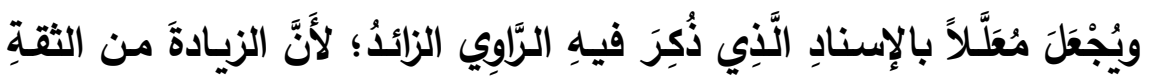

$$
\begin{aligned}
& \text { (') معرفة أنواع علوم الحديث صس صهr . }
\end{aligned}
$$

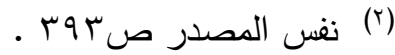

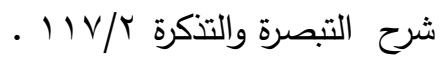

$$
\begin{aligned}
& \text { معرفة أنواع علوم الحديث صسوس . }
\end{aligned}
$$


مقبولـةُ، وإنْ كـانَ بلفظٍ يقتضـي الاتصـالَ، كـ حَدَّنَّا، وأخبرنـا، وسـمعتُ، فالحكُُ للإسـنادِ الخـالي عن الرواي الزائدِ؛ لأنَّ معَهُ الزيـادةَ، وهـيَ إثباتُ

سماعِهِ منهُُ (1).

قلت : وعليه فإنه يُفَرق بين المزبــ في متصل الأسـانيد وبين زبـادة الثقة في الإسناد بالنظر في الإسناد الخالي من الزيادة. فإن كـان الإسـناد الخـالي مـن الزيـادة ، قد صـرح فيـه بالســاع ، كانـت الزيـادة في الإسـناد الآخر من قبيـل المزيـــ في متصل الأسـانيد (ويحكم للإسناد الخالي من الزيادة بثبوت اتصاله) ولا إثكال فيه . أما إن كان الإسناد الخالي من الزيادة معنعنا عن شيخه و لـم يُصَرح فيه بالسماع فإنه يكون معلولا بتعارض الوصل والإرسـال وهو نوع من زيـادة

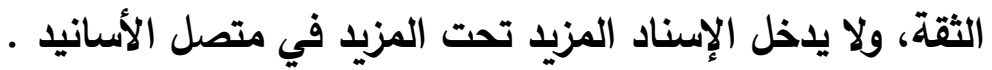
قال الدكتور حمزة بن عبد الله المليباري: وبإمعان النظر فيمـا شرحه ابن الصـلاح علمنـا أن أصل هذا النـوع يرجـع إلـى نقطة اختلاف الـرواة في الإسـناد بالزيـادة والنقص، يزيـــ البعض فيه راويـا ، ويسقطه الآخر، ممـا يشكل وحدة موضوعية مع مسألة تعارض الوقف والرفع، وتعارض الوصل والإرسـال ، وبـذلك يصبح "المزيــ في متصـل الإسـناد" جـزيا مهمـا مـن

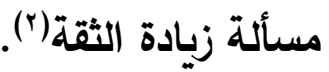

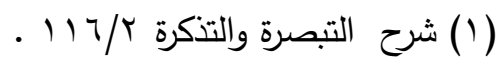

زيادة الثقة في كتب مصطلح الحديث دراسة موضوعية نقدية للدكتور حمزة بن

عبد الله المليباري ، صب كَ، ال7. الطبعة الأولى 0Y \& ا (ملتقى أهل الحديث ). 


\section{المبحث الثالث}

\section{حكم زبادة الثقة}

اختلف المحدثون في قبول زيادة الثقة، فمنهم من وافق الكثير من الأصوليين والفقهاء في منهجه بقبولها ، فقبلها مطلقا ، ومنهم من ردها مطلقا ، ومنهم من شرط لقبولها شروطا ، ومنهم من قيد القبول والرد باعتبار حال الراوي في هذه الرواية بعينها ، واعتبار ما ترجح من القرائن والملابسات المتعلقة بالرواية ، وإليك التفصيل.

الرأي الأول: رد الزيادة مطلقا : قال الخطيب : قال قوم من أصحاب

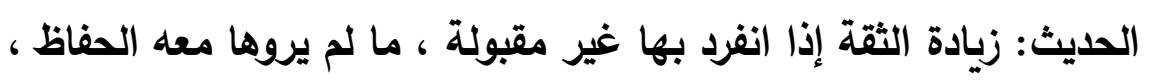
وترك الحفاظ لنقلها وذهابهم عن معرفتها يوهنها ويضعف أمرها ويكون معارضا لها(')، فحجة هذا الرأي أنه لا يعقل أن يجتمع الجماعة من الحفاظ على الشيء، ويكون قد غاب عنهم بعضه ليذكره واحد بمفرده دونهم (r).

الرأي الثاني : قبول الزيادة بشروط: وقد اشترط بعض المحثين شروطا يجب توافرها في الزيادة حتى يتم قبولها، وقد اختلفوا في تحديد هذه - الشروط

الكفايـة في علم الروايـة لأبي بكر أحمد بن علي بن ثابت بن أحمد بن مهدي الخطيب البغدادي (المتوفى: بآگهـ)

تحقيق : أبو عبدالله السورقي , إبراهيم حمدي المدني ، ط: المكتبة العلميـة - المدينة

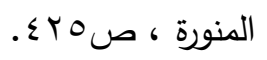

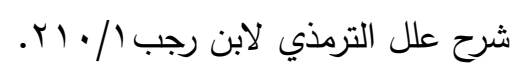


ا - فمنهم من قال: إن كانت مخالفة في الحكم لما رواه الباقون لم تُقبل، وإلا قبلت، كما لو تفرد بالحديث كله، فإنه يقبل تفرده به إذا كان ثقة

\section{ضابطاً أو حافظاً. وقد حكى الخطيب على ذلك الإجماع|'.}

وذلك لأنها إن كانت منافية لما رواه الثقات فهي رواية شاذة مردودة كما

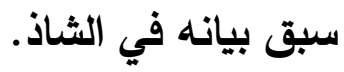

ץ-ومنهم من قال: "إن كان الممسك عن الزيادة أضبط من الراوي لها فلا تقبل. وكذا إن صرح بنفيها، وإلا قبلت" ، قاله الإمام فخر الدين(؟). وقال الدار قطني: ما جاء بلفظة زائدة، فتقبل تلك الزيادة من متقن، ويحكم لأكثرهم حفظا وثبتا على من دونه"(").

وقال ابن عبد البر في "التمهيد": "إنما تقبل الزيادة من الحافظ إذا ثبت عنه وكان أحفظ وأتقن ممن قصر أو مثله في الحفظ، كأنه حديث آخر

مستأنف (£)

$$
\begin{aligned}
& \text { (1) الباعث الحثيث إلى اختصار علوم الحديث صاب (1) }
\end{aligned}
$$

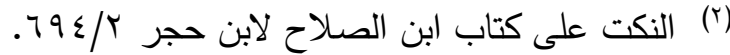

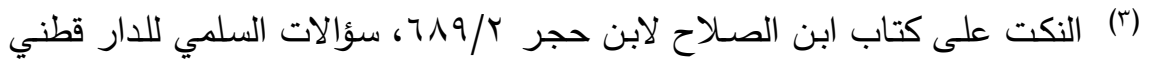
ص. מדז .

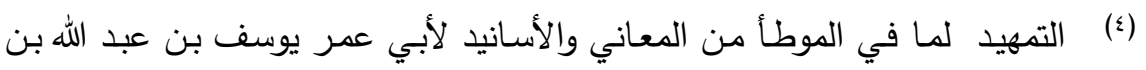

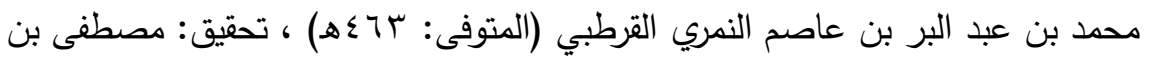
أحمد العلوي , محمد عبد الكبير البكري ، ط: وزارة عموم الأوقاف والثؤون الإسـلامية -

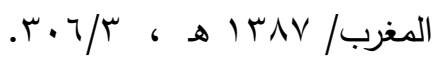


أي أنهم اعتبروا المفاضلة في الضبط والإتقان بين من روى الزيادة وبين من سكت عنها ، فإن كان من روى الحديث خاليا من الزيادة أضبط ممن رووه بالزيادة ردت الزيادة ، والعكس صحيح •

ץ-ومنهم من قال: "إن اتعد المجلس فإن كان من لم يروها، قد انتهوا إلى حد لا تقتضي العادة غفلة مثلهم عن سماعها ، والذي رواها واحد فهي مردودة وإن لم ينتهوا إلى هذا الحد" ، قاله الآمدي وجرى عليه

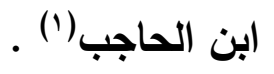

أي إن سمع الحديث جماعة في مجلس واحد فرواه أحدهم بالزيادة ، ورواه الآخرون بدونها، فإن كان هؤلاء الذين رووا الحديث خاليا من الزيادة تقتضي العادة عدم غفلتهم لكثرتهم وضبطهم ...فالزيادة مردودة. ع -ومنهم من قال: تُقبل الزيادة إذا كانت من غير الراوي، بخلاف مـا إذا نشط فرواها تارة وأسقطها أخرى(ץ). وقد حكي عن فرقة ممن ينتحل مذهب الثافعي أنها قالت: تقبل الزيادة من الثقة إذا كانت من جهة غير الراوي، فأمـا أن يكـون هـو الـذي روى النـاقص، ثـم روى الزيـادة بعـ فإنهـا لا تقبل (ץ). أي أنها لا تقبل من الراوي الذي روى الحديث خاليا من الزيـادة ثم رواه بالزيـادة، لمـا فيـه مـن إثـعار بقلـة الضـبط والتـوهم إذ قـ رواهـا على الوجهين، وإنما تقبل من غيره الذي رواها بالزيادة على وجه واحد .

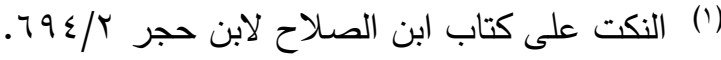

$$
\begin{aligned}
& \text { الباعث الحثيث إلى اختصار علوم الحديث لابن كثير ص آح. }
\end{aligned}
$$

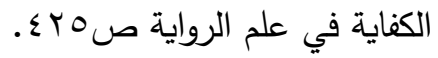


هـومنهم من قال: إن اتحد مجلس السماع لم تقبل، وإن تعدد قُبلت (1). أي لا تُقبل الزيادة من الراوي الذي تفرد بها عن بقية الرواة إن كانوا قـ سمعوا الحديث جميعا في مجلس واحد لزيادة احتمال غفلته وسهوه ، أما إن تعدد مجلس السماع فسمع الحديث في مجلس غير مجلسهم فتقبل زيادته ، لاحتمال أن يكون الشيخ رواه في مجلس ناقصا ، ثم رواه في مجلس آخر زائدا فسمعه منه. وذكرَ ابنُ الصبّاغِ في " العدّةٍ " فيما إذا روى الواحدُ خبراً، ثمَّ رواهُ بعدَ ذلكَ بزيادةٍ، فإنْ ذكرَ أنَّهُ سمعَ كلَّ واحدٍ منَ الخبرينِ في مجلسينِ، قُبَّتِ

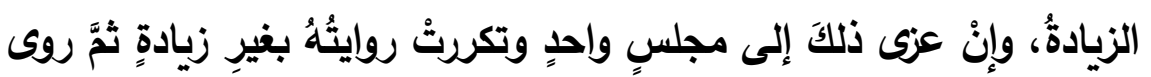

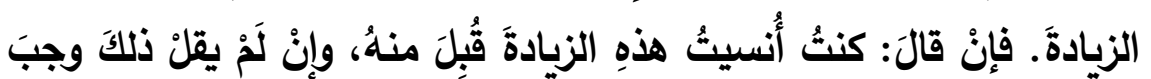

$$
\text { التوقّفُ في الزيادةِّ(؟). }
$$

ه-ومنهم من قبلها إذا أفادت حكما يتعلق بها ،فأما إذا لم يتعلق بها حكم فلا) (").

צ-وقال آخرون: يجب قبول الزيادة من جهة اللفظ دون المعنى(؛) . V-وقيل: إنْ كانتِ الزيادةُ مغيرةً للإعرابِ، كانَ الخبرانِ متعارضينِ، وإنْ لَّْ

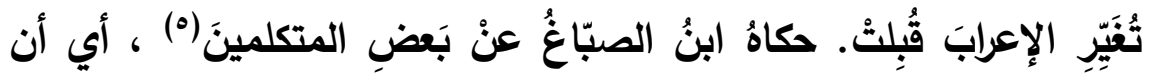
الزيادة مقبولة شريطة عدم تغير الإعراب .

$$
\begin{aligned}
& \text { (') الباعث الحثيث إلى اختصار علوم الحديث ص ال7. }
\end{aligned}
$$

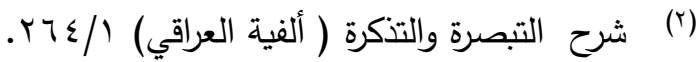

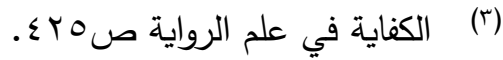

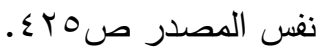

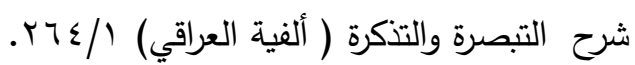


^- وقيل: ينظر في في راوي الزيادة ، وموضعها ، فمن كان الغالب عليه الفقه لا تقبل منه الزيادة في الإسناد؛ لأن الغالب عليه أحكام المتن إلا اذا كانت الزيادة من كتابه، ومن كان الغالب عليه الحديث لا تقبل منه الزيـادة في المتن إلا اذا كانت الزيـادة من كتابه؛ لأن الغالب عليه أحكام السند. وذلك لأن أصـحاب الحديث الغالب عليهم حفظ الأسـامي والأسـانيد دون المتون، والفقهاء الغالب عليهم حفظ المتون وأحكامها وأداؤها بالمعنى،

دون حفظ الأسانيد وأسماء المحدثين، وقد حكي ذلك عن ابن حبان ('). الرأي الثالث : قبول الزيادة مطلقا على كل الوجوه مـادام لويها حافظا ضـابطا: وعلى رأس القـائلين بذلك الخطيب البغدادي ، قال الخطيب البغدادي: والذني نختاره من هذه الأقوال أن الزيـادة الواردة مقبولـة على كل الوجهوه ، ومعمـول بها إذا كـان راويها عدلا حافظا ومتقنـا ضابطا ، والدليل على صحة ذلك أمور، أحدها: اتفاق جميع أهل العلم على أنه لو انفرد الثقة بنقل حديث لم ينقله غيره ، لوجب قبوله ، ولم يكن ترك الرواة لنقله إن كانوا عرفوه وذهابهم عن العلم بـه معارضـا له، ولا قادحا في عدالة راويـه ، ولا مبطلا لـه ، فكذلك سبيل الانفراد

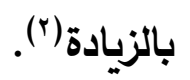

وقــ وافقق الخطيب جماعـة مـن المحـثين فقبلـوا زيـادة الثقــة على كـل الوجوه، وسيأتي بيانهم عند تفنيد الآراء.

انظر صحيح ابن حبان /09/1 بتصرف، أثر علل الحديث في اختلاف الفقهاء

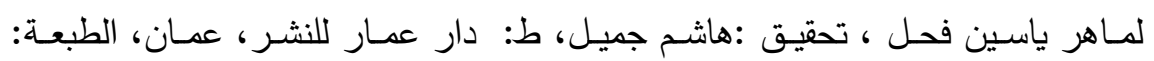

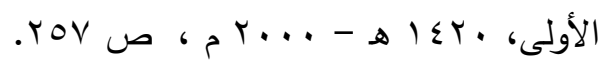

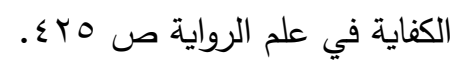


الرأي الرابع :اعتبار الترجيح بالقرائن: قال ابن حجر: الأي يجري على قواعد المحثثين أنهم لا يحكمون عليه بحكم مستقل من القبول والرد،

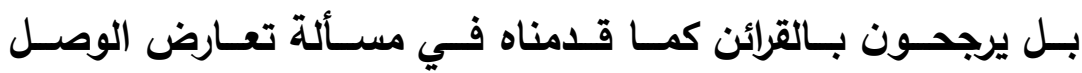

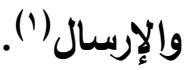

وقال البقاعي معقبا على ابن الصـلاح: على أنَّ لحذاقِ المحدّثينَ في

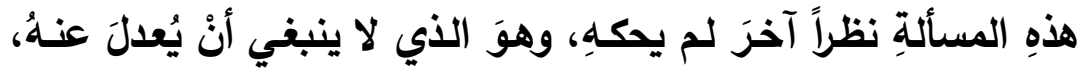

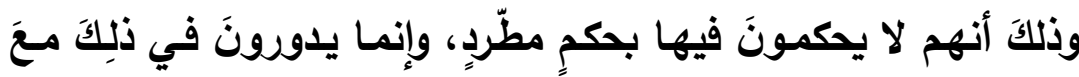

القرائن (r)

القول بأن قبـول الزيـادة مـذهب لجمهور المحدثين، والرد على ذلكة ومناقشة الآراء وتفنيدها، وبيان الراجح منها:

مما سبق يتضح اختلاف أصحاب الحديث وتباين مذاهبهم في قبول زيـادة الثقة، إلا أننا نجد مَن سـاوى بين جمهور الفقهاء وأصحاب الحديث في هذه المسألة ، فأطلقوا القول بأن مذهب جمهور الفقهاء وأصحاب الحديث هيث

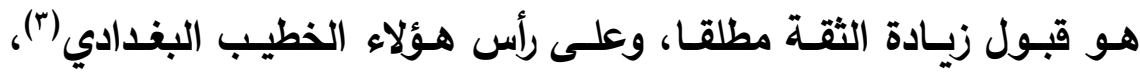

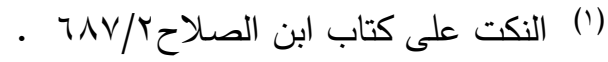

(r) النكت الوفية بما في شرح الألفية لبرهان الدين إبراهيم بن عمر البقاعي، تحقيق:

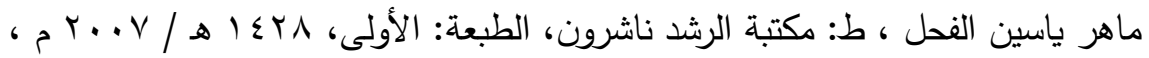
.$\leqslant r y / 1$ انظر الكفاية صع ع ع. 
والنووي(') وتبع الخطيب كلا من ابن الصلاح(r) والعراقي() فنقلا عنه ذلك ، بل وادعى ابن طاهر الإتفاق على ذلك بين أهل الحديث(؛) وقـد خـالفهم الحـافظ (بـن حجـر (0) ، وابـن رجب الحنبلـي(") ، والإمــام الزيلعي(v)، والعلائي(^) ، وسأعرض تفصيلا رأي كلا الفريقين.

أولاً: قال الخطيب البغدادي : قال الجمهور من الفقهاء وأصحاب الحديث: زيادة الثقة مقبولة ، إذا انفرد بها، ولم يفرقوا بين زيـادة يتعلق بها حكم

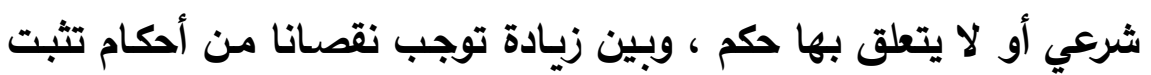
بخبر ليست فيه تلك الزيادة ، وبين زيـادة توجب تغيير الحكم الثابت ، أو زيادة لا توجب ذلك ، وسواء كانت الزيادة في خبر رواه راويـه مرة ناقصـا ، ثم رواه بعد وفيه تلك الزيادة ، أو كانت الزيـادة قد رواهـا غيره ولم يروهـا

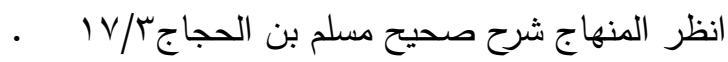

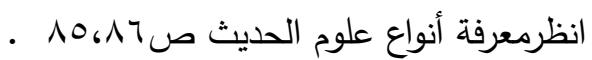

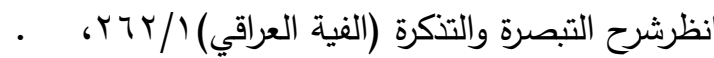

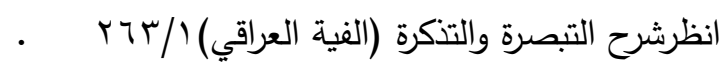

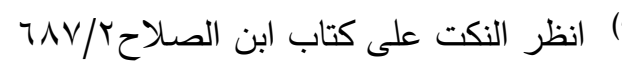

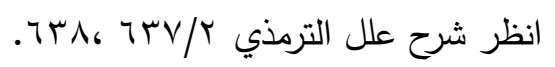

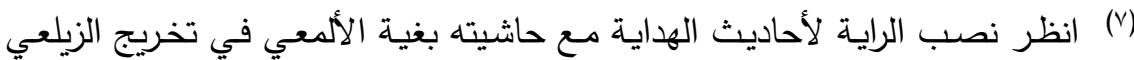

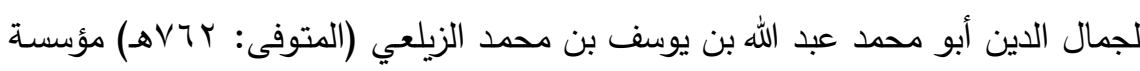
الريان للطباعة والنشر - بيروت -لبنان/ دار القبلة للثقافة الإسلامية- جدة - السعودية

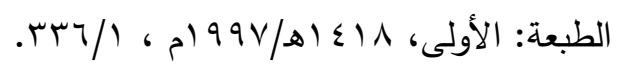

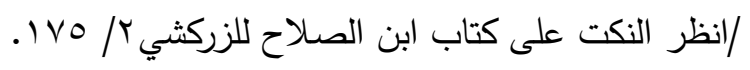

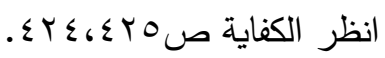


وقال ابن الصـلاح: مذهب الجمهور من الفقهاء وأصساب الحديث فيما حكاه الخطيب أبو بكر: أن الزيـادة من الثقة مقبولة إذا تفرد بها، سواء كان ذلك من شخص واحد بأن رواه ناقصا مرة ورواه مرة أخرى وفيه تلك الزيادة، أو كانت الزيادة من غير من رواه ناقصسا. خلافا لمن رد من أهل الحديث ذلك مطلقا، وخلافا لمن رد الزيادة منه وقبلها من غيره، وقد قدمنا عنه حكايته عن أكثر أهل الحديث فيما إذا وصل الحديث قوم وأرسله قوم: أن الحكم لمن أرسله، مع أن وصله زيادة من الثقة (1). وقال العراقي: ذهبَ الجمهورُ مسنَ الفقهاءِ وأصحابِ الحديثِ، كمـا حكـاهُ

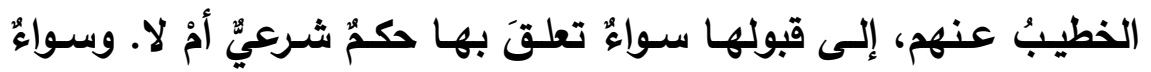

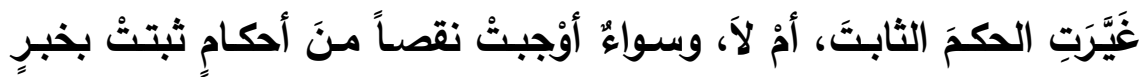

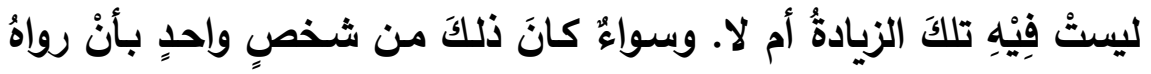

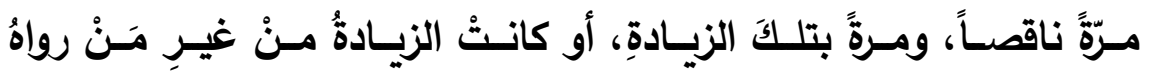

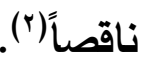
وقال النووي: "زيادات الثقة مقبولة مطلقاً عند الجماهير من أهل الحديث والفقه والأصول"(")

إذًا فالقول بقبول الزيـادة مطلقا هو مـا اختاره الخطيب البغدادي ثم نص

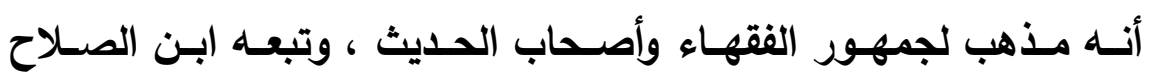


والعراقي ونقـلا عنـهـ ذلكـ ، ووافقـه الإمـام النـووي، وإن كـان لأصـحاب الحديث آراء أخرى كما صرح الخطيب نفسه بذلك، وكذا ابن الصلاح .

وعلى الرغم من موافقة ابن الصلاح للخطيب إلا أنه ذكر عن الخطيب مـا يناقض مذهبه في قبول زيـادة الثقة، حيث حكى عن الخطيب أن أكثر المحثثين يذهبون إلى تقديم الإرسال على الوصل عند التعارض رغم أن

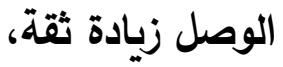

فقال ابن الصلاح: "وقد قدمنا عنه حكايته عن أكثر أهل الحديث فيما إذا وصل الحديث قوم وأرسله قوم: أن الحكم لمن أرسله، مـع أن وصله زيـادة من الثقة"(1).

وقد أشار ابن رجب إلى تناقض الخطيب نفسه في مسألة قبول زيادة الثقة حيث خالف كلامه في "الكفاية" كلامه في مصنفه الآخر "تمييز المزيـ في متصل الأسانيد" واللي حكم فيه أحيانا برد الزيادة .

قال ابن رجب الحنبلي: " وقد صنف في ذلك الحافظ أبو بكر الخطيب مصنفاً حسناً سـماه "تمييز المزيــ في متصل الأسـانيد" وقسمه قسمين: أحدهما: ما حكم فيه بصحة ذكر الزيادة في الإسناد، وتركها. والثاني: مـا حكم فيه برد الزيادة وعدم قبولها. ثم إن الخطيب تناقض فذكر في كتاب "الكفايـة" للنـاس مذاهب في اختلاف الرواة في إرسـال الحديث ووصله، كلها لا تعرف عن أحد من متقدمي الحفاظ إنمـا هي مـأخوذة من كتب إن المتكلميني، ثـم إنــه اختـار أن الزيـادة مـن الثقــة تقبـل مطلقـاً، كمـا نصـره المتكلمـون وكثير مـن الفقهاء ، وهذا يخـالف تصـرفه في كتـاب تمييز 
المزيل" وقد عاب تصرفه في كتابهه" تمييز المزيــ "بعض محدثي الفقهاء

$$
\text { وطمع فيه لموافقته لهم في كتاب "(لكفاية(1)" . }
$$

وعقب الزركشي منتقدا قول الخطيب أن قبول زيادة الثقة مذهب لجمهور المحدثين، فقال: وقد نوزع في نقله ذلك عن جمهور المحدثين. وعمدتهم هو أن الواحد لو انفرد بنقل حديث عن جميع الحفاظ قبل، فكذلك إذا انفرد بالزيـادة؛ لأن العـدل لا يـتهم، وهـو مـردود، فـإن تفـرد بأصـل الحـديث لا يتطرق الوهم إلى غيره من الثقات، بخـلاف تفرده بالزيـادة إذا خـالف من هو أحفظ، فإن الظن مرجح لقولهم دونه، لا سيما عند اتحاد المجلس(ب). قلت: وعليـه فـإن إطـلاق القول بـأن قبـول زيـادة الثقـة مـذهب لجمهور المحـثين كمـا ادعـاه الخطيـب والنـووي نظر كبيـر ، فضـلا عن ادعـاء الإتفاق على ذلك ، كما ادعاه ابن طاهر بقولـه: "لا خـلافَ تجدُهُ بينَ أهلِ

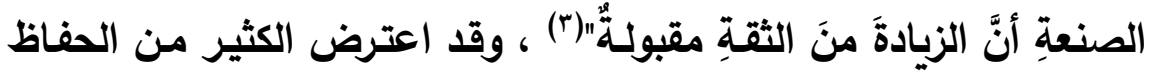
على ذلك، إذ لو كانت زيادة الثقة مقبولة على الإطلاق لاقتضى ذلك قبول الزيادة التي تفرد بها الثقة مخالفا بها من هو أوثق منـه وهذا هو عين الحديث الشاذ.

يقول ابن حجر: "اشتهر عن جمع من العلماء القول بقبول الزيادة مطلقا، من غير تفصيل، ولا يتأتى ذلك على طريق المحثين الذين يشترطون في

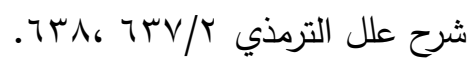

البحر الدحيط في أصول الفقه لأبي عبد الله بدر الدين محمد بن عبد الله بن بهادر

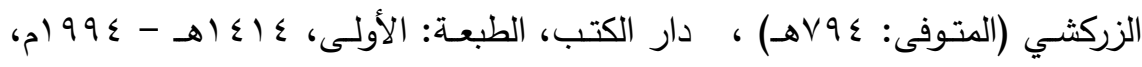


الصحيح أن لا يكون شـاذا، ثم يفسرون الثذذوذ بمخالفـة الثقة مـن هو أوثق منه .

والعجب ممن أغفل ذلك منهم، مع اعترافه باشتراط انتفاء الشذوذ في حد الحديث الصحيح، وكذا الحسن(') قلت : واشثتراط انتفـاء الثـذوذ لقبول الحديث هو الثرط الذي امتاز بـه المحدثون عن غيرهم، من الأصوليين والفقهاء ، فجمهور الفقهاء على

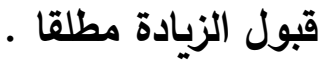
قال ابن دقيق العيد مبينا حد الحديث الصحيح : وزاد أصحاب الحديث أن لا يكون شـاذا ولا معلـلا، وفي هذين الثـرطين نظر على مقتضسى مذهب الفقهاء فإن كثيرا من العلل التي يعلل بها المحدثون الحديث لا تجري على ملى ملى ملئ أصول الفقهاء (r) وقد استشكل الحافظ ابن حجر على ابن الصـلاح تقديمسه الوصل مطلقا عند تعارض الوصل والإرسـال، وإن كان رواة الإرسـال أحفظ أو أكثر، مـع اشتراطه في الصحيح ألا يكون شاذا ، ثم اعتذر عنه بأنـه ربمـا أخذ فيه الإنه بـرأي الفقهـاء الــين لا يشـترطون انتفــاء الشــوذ للحكـم على الحــيث بالصحة .

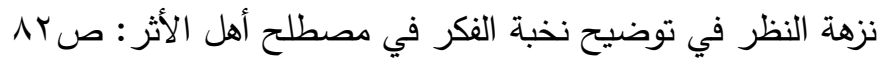

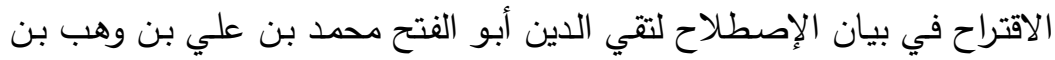

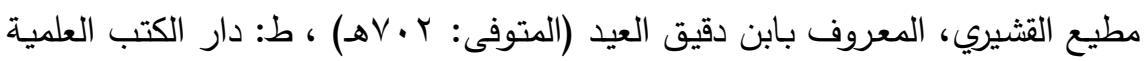

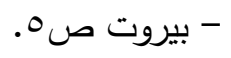


قال الحافظ ابن حجر : "وعلى المصنف(') إشكال أشـد منـه؛ وذلك أنسه يشترط في الصـيح أن لا يكون شـاذا ويقول: إنـها لـو تعـارض الوصل

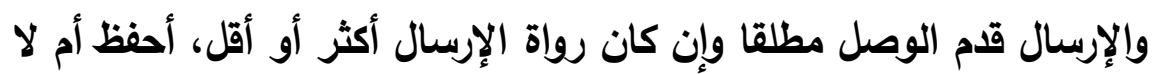
، ويختار في تفسير الثاذ أنه الأي يخالف راويها من هو أرجح منـه، وإذا

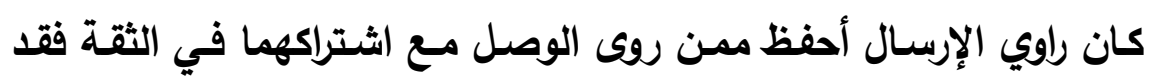
ثبت كون الوصل شاذا، فكيف يحكم لـه بالصحة مـع شرطه في الصحة

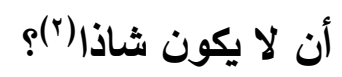

قال: "هذا غاية في الإثكال ثم قال: يمكن أن يجاب عنه بأن اشتراط نفي الثذوذ في شرط الصحة إنما يقوله المحثثون وهم القائلون بترجيح روايـة الأحفـظ إذا تعـارض الوصـل والإرســال، والمصـنف يأخــ بقـول الفقهـاء والأصوليين وذلك أنهم لا يشترطون نفي الثذوذ في شرط الصحيح وبهذا يرتفع الإثكال(r)

وتعقب الحافظ ابن حجر الحاكم وابن حبان والنووي، وجماعة من أهل الفقـه والأصـول ممن قبلوا الزيـادة مطلقـا(؛) ، فقـال ابن حجر :"وفيه نظر كثير لأنه يرد عليهم الحديث الذي يتحد مخرجه فيرويه جماعة من الحفاظ الأثبات على وجـه، ويرويـه ثقـة دونهم في الضبط والإتقان ، على وجـه يشمل على زيادة تخالف ما رووه إما في المتن وإمـا في الإسناد ، فكيف تقبل زيادته وقد خالفه من لا يغفل مثلهم عنها لحفظهم أو لكثرتهم ، ولا

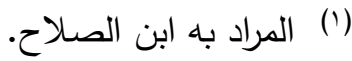

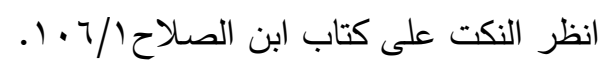

$$
\begin{aligned}
& \text { انظر نفس المصدر //7 • 1. }
\end{aligned}
$$

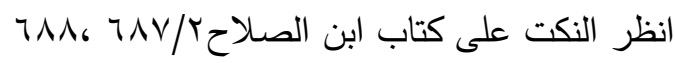


سـيما إن كـان شـيخهم ممسن يجمـع حديثـه، ويعتــى بمروياتــه كـالزهري وأضـرابه، حيث يقـال: إنـا لـو رواهـا لسـمعها منـه حفـاظ أصـحابه، ولـو سمعوها لرووها ولما تطابقوا على تركها، والذي يغلب على الظن في هذا وأمثاله تغليط راوي الزيادة('). وقال ابن حجر بعد استعراضـه أقوال الأئمسة في زيـادة الثقة: حاصل كـلام هؤلاء الأئمة أن الزيادة إنما تقبل ممن يكن حافظا متقنا حيث يستوي مـع

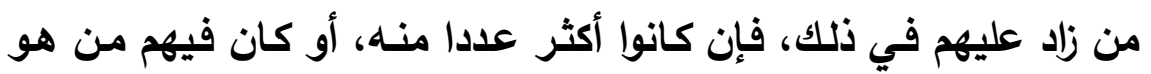
أحفظ منه، أو كان غير حافظ ولو كان في الأصل صدوقا ، فبإن زيادته لا تقبل، وهذا مغاير لقول من قال: زيادة الثقة مقبولة وأطلق (). كــا أوضـح الحسافظ ابـن حجر أن مـا صـرح بـه الخطيب عن جمهور المحدثين بقبول زيادة الثقة مشروطا بكون الراوي عدلا ضـابطا بخلاف الفقهاء الأين يثترطون العدالة فقط ـ ففال: الأي صححه الخطيب - شرطه أن يكون الراوي عدلا ضـابطا، أمـا الفقهاء والأصوليون، فيقبلون ذلك من العدل مطلقا، وبين الأمرين فرق كثير (r) وقال الزيلعي في معرض ردّه على من قَبِل الزيادة مطلقا:

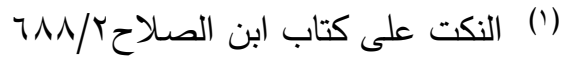

$$
\begin{aligned}
& \text { (r) النكت على كتاب ابن الصلاحج/ / . } 79 . \\
& \text { (r) نفس المصدر r/ T/T. }
\end{aligned}
$$


قلنـا: ليس ذلك مجمعا عليه، بـل فيه خـلاف مشهور، فمن النـاس من يقبل زيـادة الثقة مطلقا، ومنهم من لا يقبلها، والصحيح التفصيل، وهو

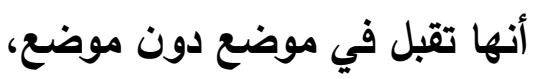

- فتقبل إذا كان الراوي الذي رواها ثقة حافظا ثبتا، والذي لـ يذكرها مثلـه، أو دونـه في الثقـة، كمـا قبل النـاس زيـادة مالك بن أنس،

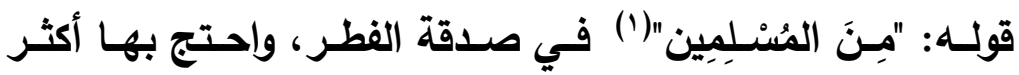
العلماء، - (اء،

- - وتقبل في موضـع آخر لقرائن تخصها، ومن حكم في ذلك حكما عاما فقد غلط، بل كل زيادة لها حكم يخصها ، - ففي موضع يجزم بصحتها، كزيادة مالك (r)، - وفي موضع يغلب على الظن صحتها، كزيـادة سعد بن طارق(")

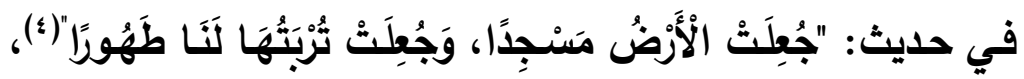

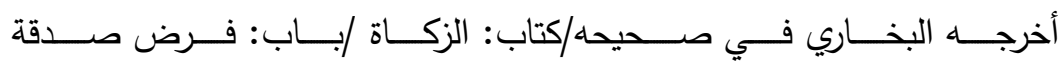

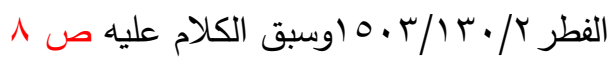
(r) أي زيادة مالك بن أنس في قوله " من المسلمين" بالحديث السابق.

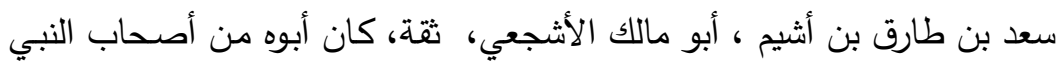

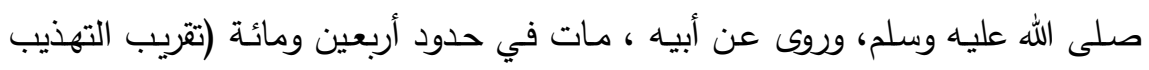

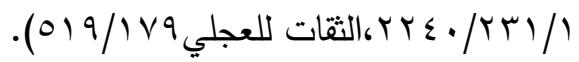

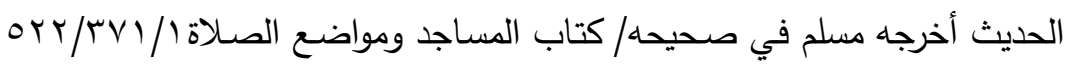

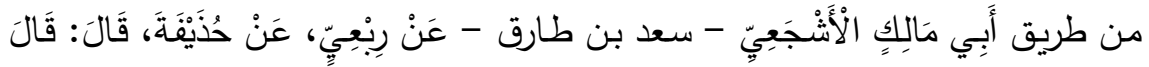

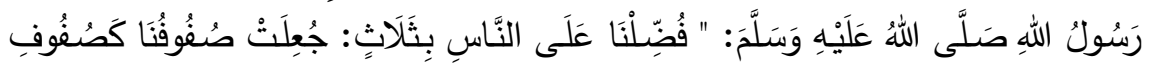

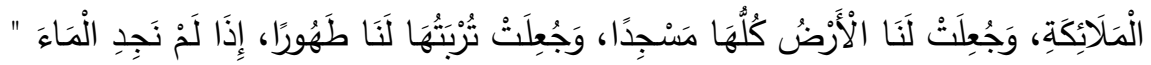
$==$ 


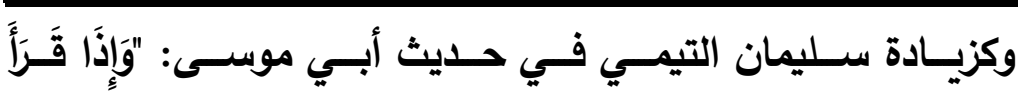

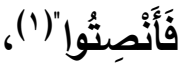

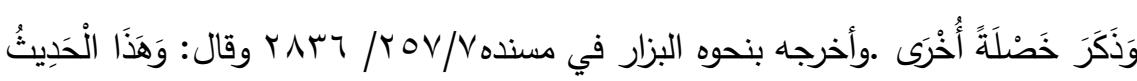

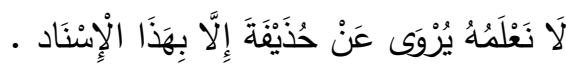

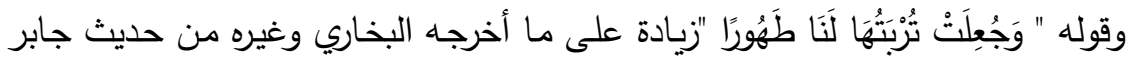

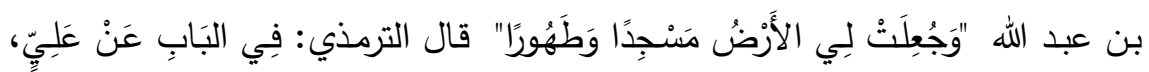

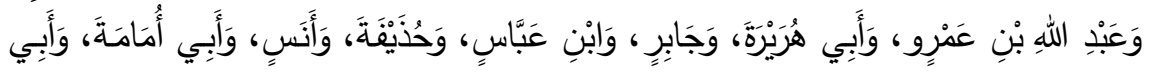

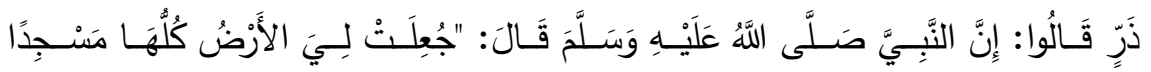

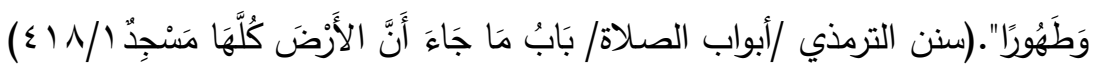

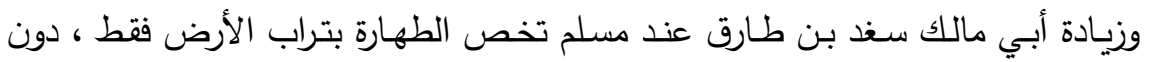

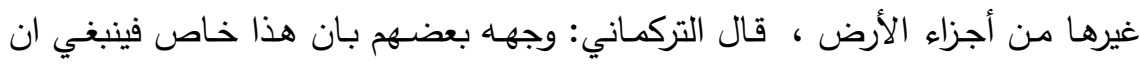

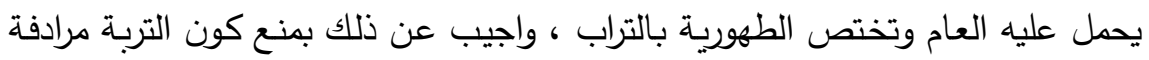

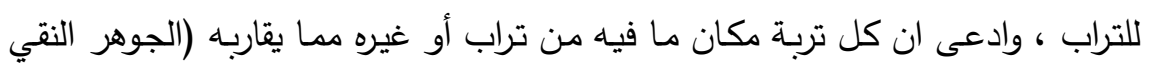

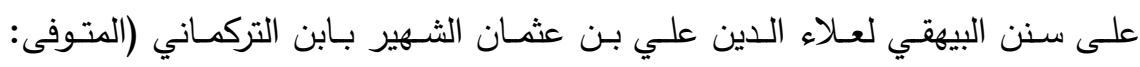

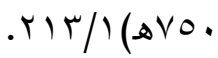

قلت: وينتبه إلى اختلاف مخرج الحديث، إذ الزيادة من طريق حذيفة رضي الله عنه، وقد روي الحديث عدد من الصحابة بدونها.

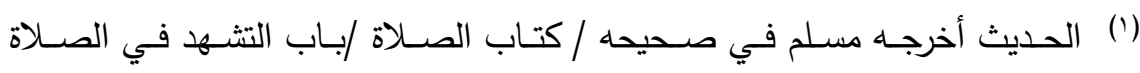

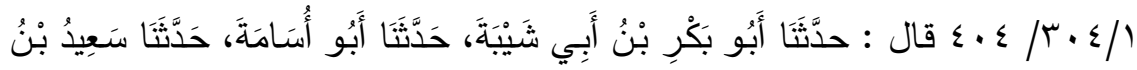

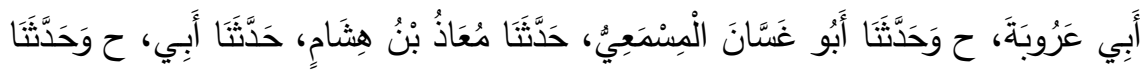

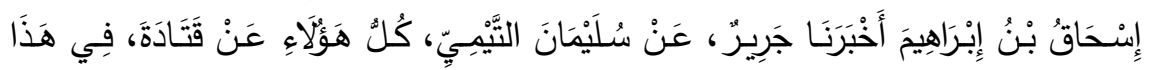

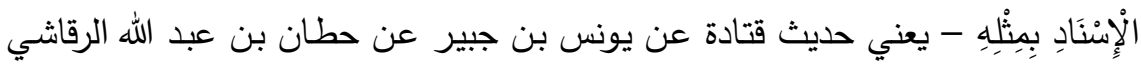

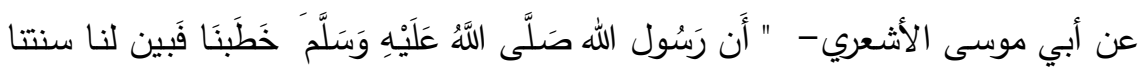

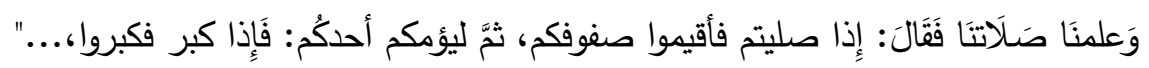
$==$ 
- وفي موضع يجزم بخطأ الزيادة، كزيادة مَعْمَر، ومن وإفقه، قوله:

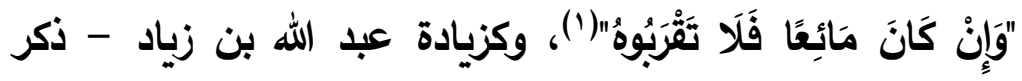

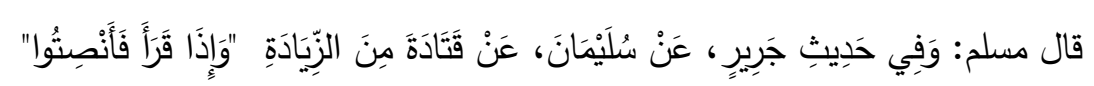

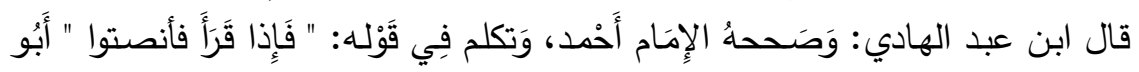

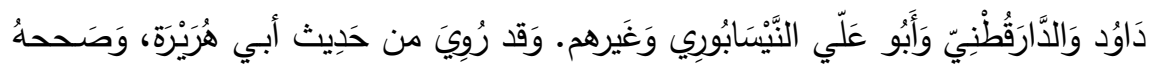

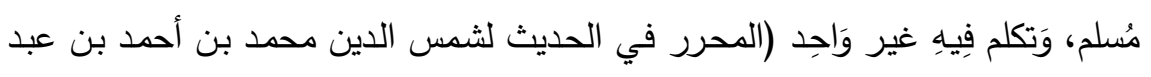

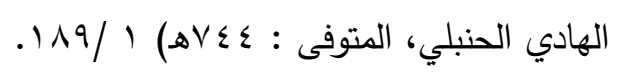

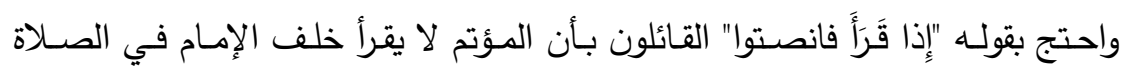

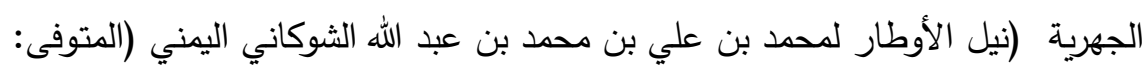
. ro./r (ن) ro.

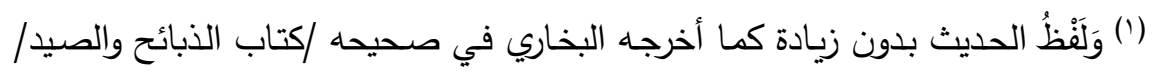

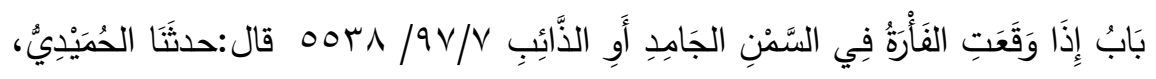

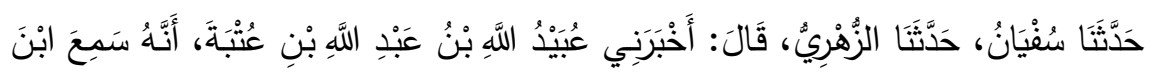

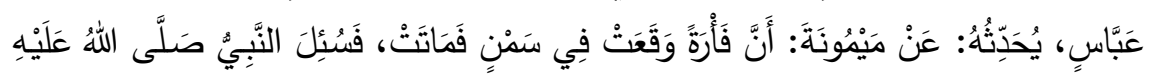

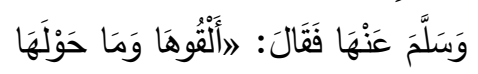

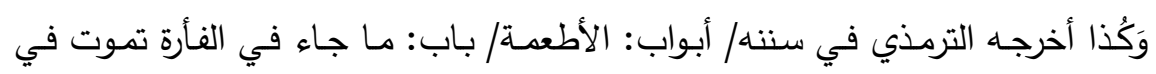

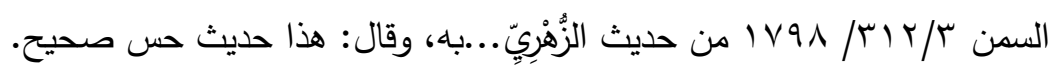

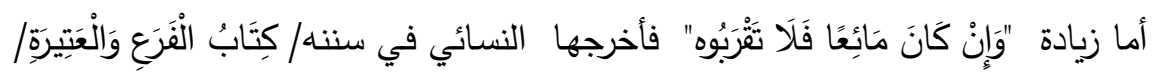

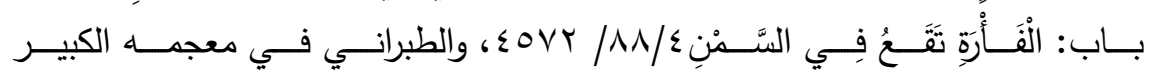

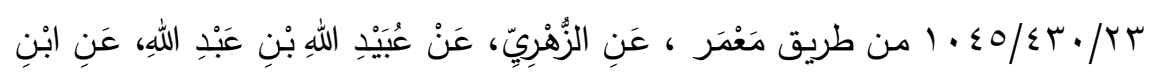

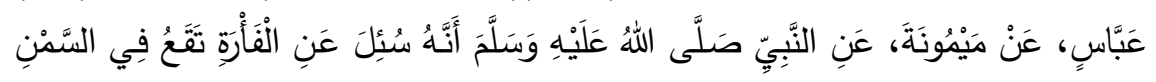

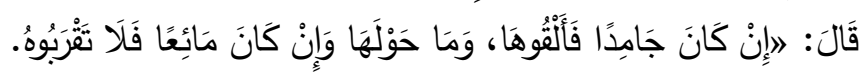

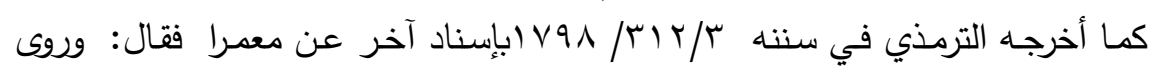

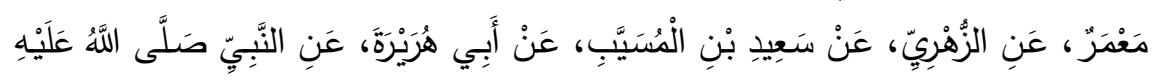
$=$ 
البسملة في حديث "قَسَمْتُ الصَّلَاةَ بَيْنِي وَبَيْنَ عَبْدِي نِصْفَيْنِ"(1)،

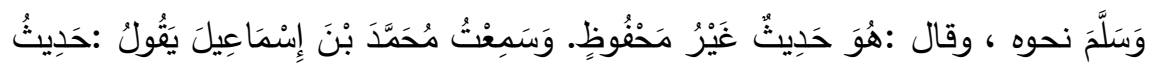

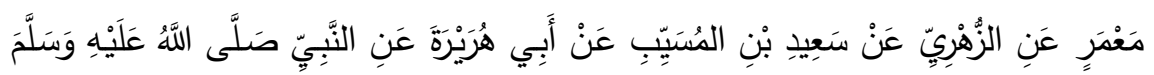

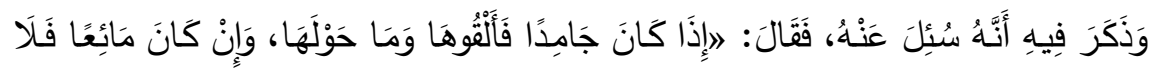

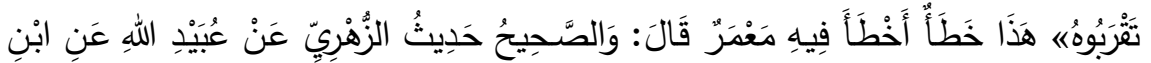

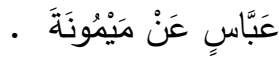
قلت: وبهذا يكون معمر قد أخطأ في إسناد الحديث كما قرره البخاري والترمذي، ، كما

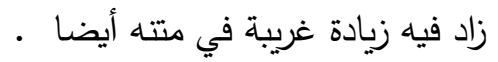
إلا أن ابن حبان أخرج حديث معمر بكلا الإسنادين عن ميمونة وأبي هريرة ، ولم

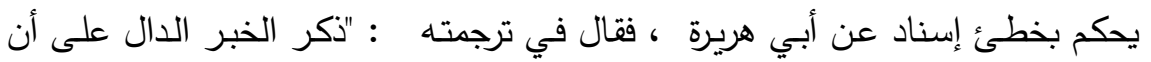

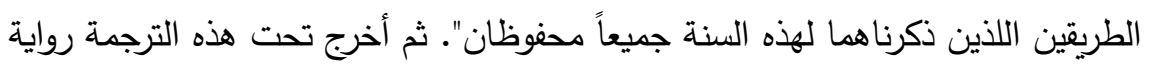

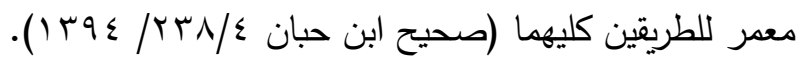

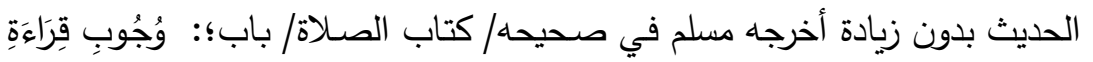

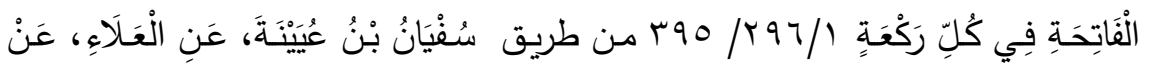

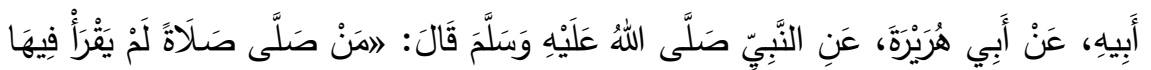

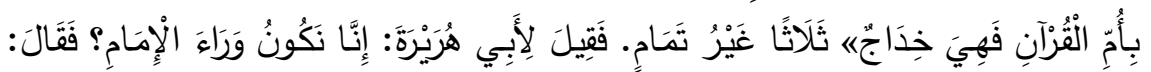

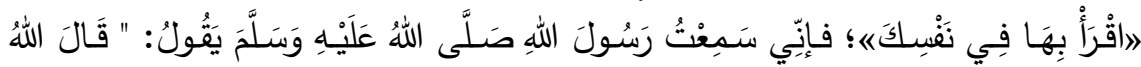

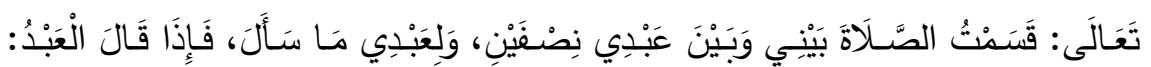

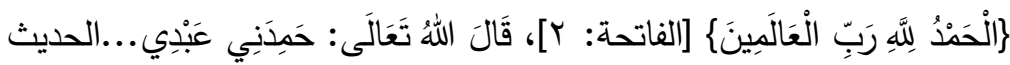

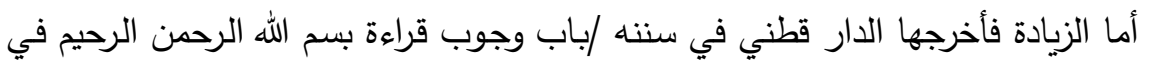

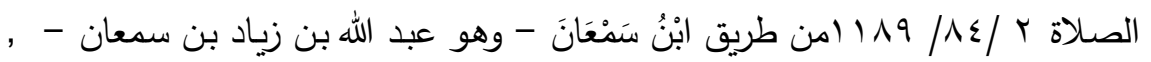

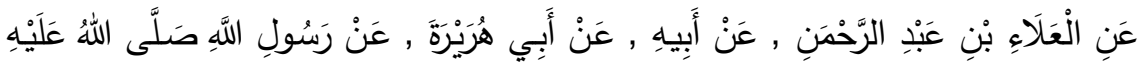

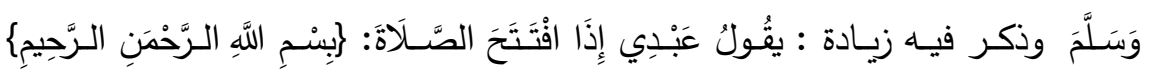

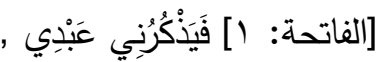
$==$ 
وإن كان مَعْمَر ثُقة"(1). وعبد الله بن زباد ضعيفا(؟)، فإن الثقة قد

يغلط

- وفي موضـع يغلب على الظن خطؤهـا، كزيـادة مَعْمَر في حديث

ماعز الصلاة عليه، رواها البخاري في صحيحه، وسئل هل رواها

$=$

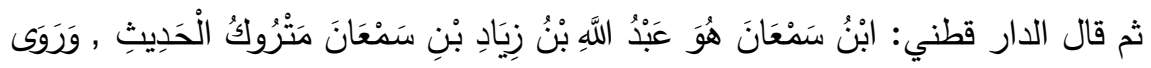

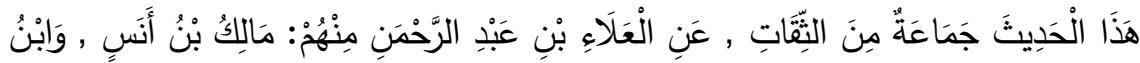

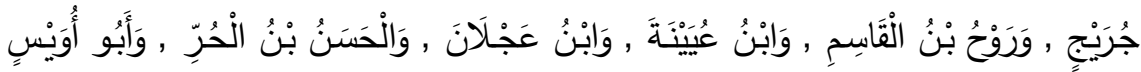

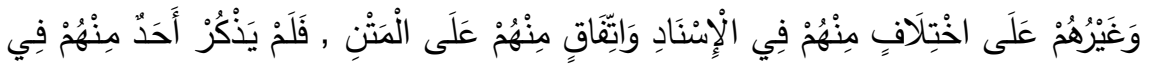

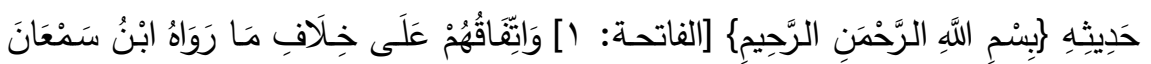
أَوَتَلَى بِالصَّوَابِ

وقال الزيلعي: هذه الرواية انفرد بها عنه ابن سمعان، وهو كذاب، ولم يخرجها أحد من أصحاب الكتب الستة، ولا في المصنفات المشهورة. ولا المسانيد المعروفة، وإنما رواه ونهاه

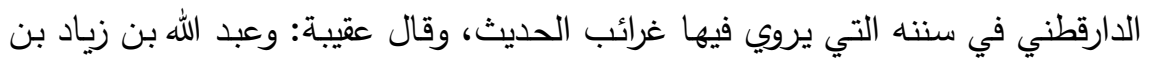

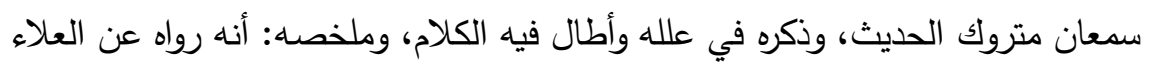

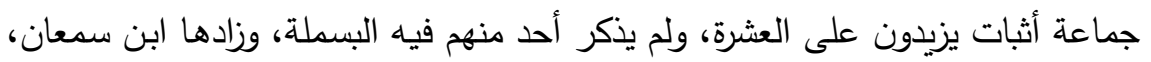

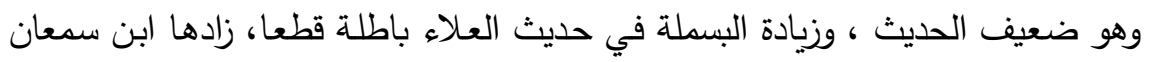

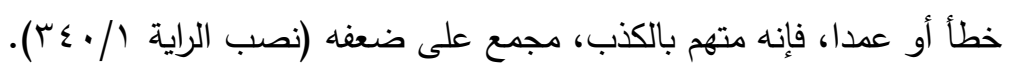

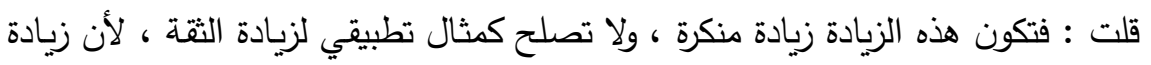

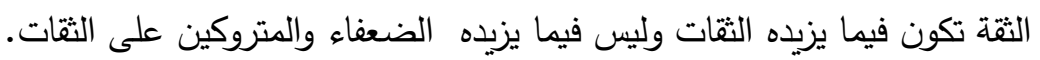

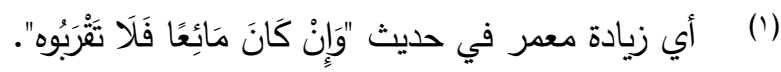

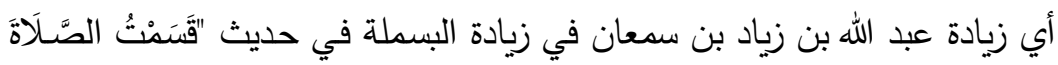
بَيْنِي وَبَبْنَ عَبْدِي نِصْفَيْنِ". 


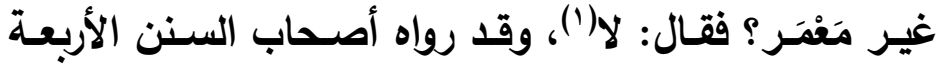

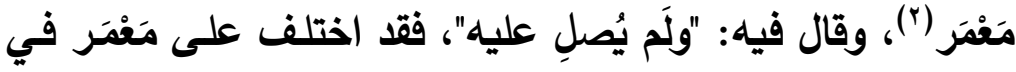
ذلك، والراوي عن مَعْمَر هو عبد الرزاق وقد اختلف عليه أيضسا،

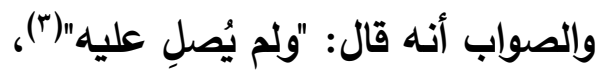

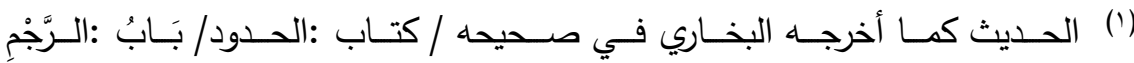

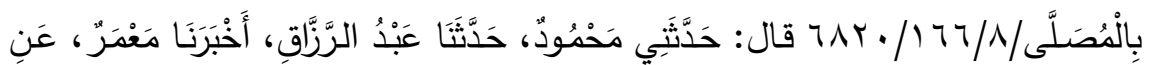

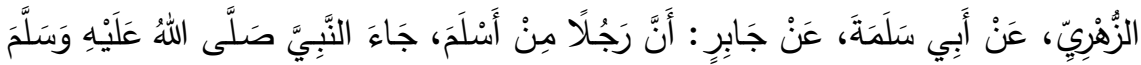

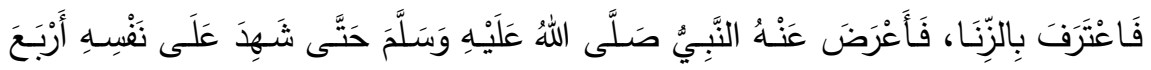

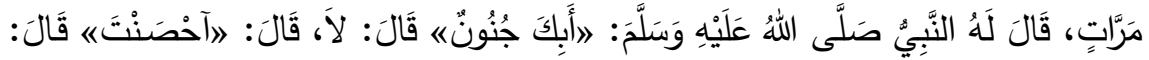

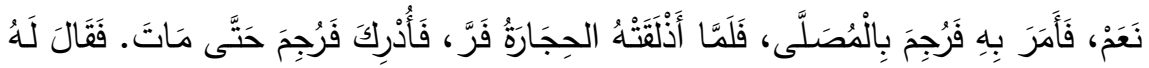

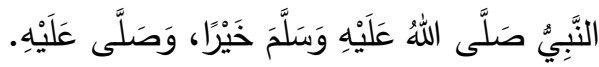

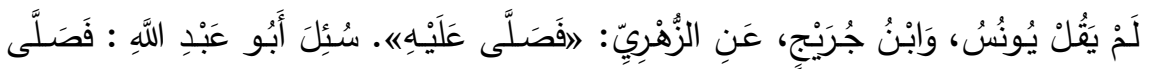

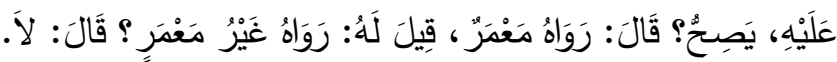

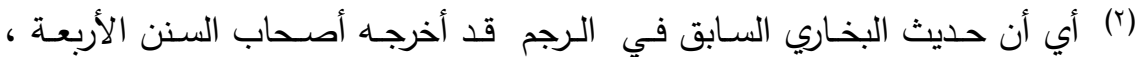

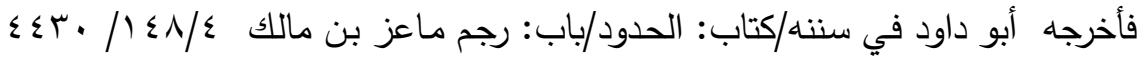

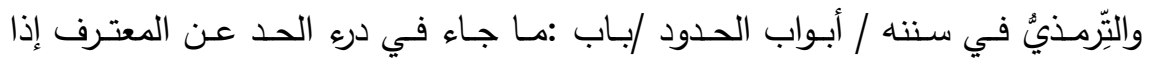

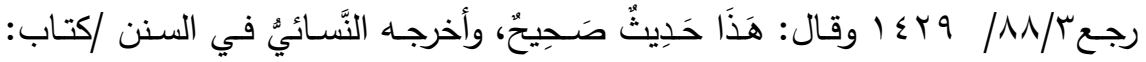

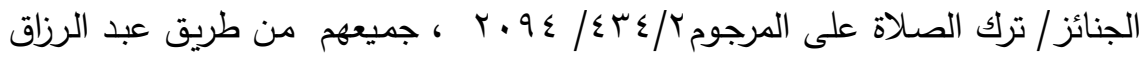

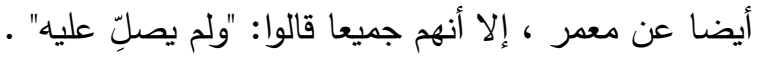

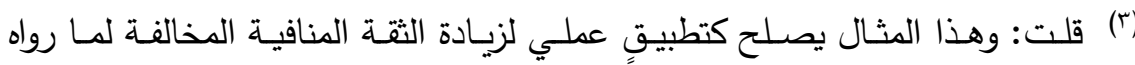
الثقات، فقد رواه أصحاب عبد الرزاق عن معمر فقالوا:"ولم يصل عليه "، وتفرد محمود

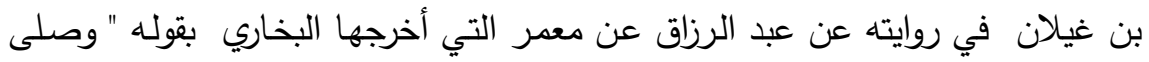

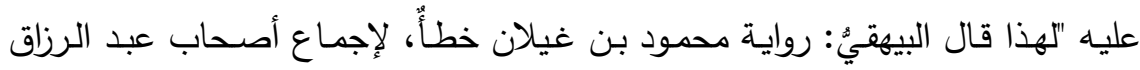
$==$ 
- مفي موضع يتوقف في الزيادة، كما في أحاديث كثيرة، وزيادة نُعَيْمٍ الْمُجْمِِِ التسمية في هذا الحديث(') مما يتوقف فيه، بل

يظلب على الظن ضعفه(r).

قلت: وعند النظر إلحى صنيع المحدثين والحفاظ في مصنفاتهم، والإمعان في تطبيقـاتهم العمليـة لزيـادة الثقـة في الأحاديـث، نجد أنهم لا يقبلون

$=$

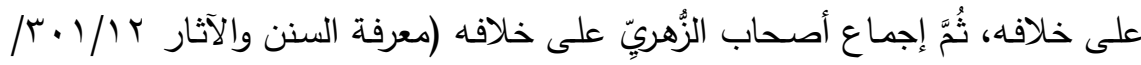
ع

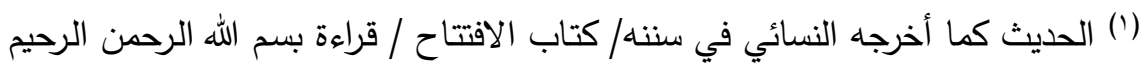

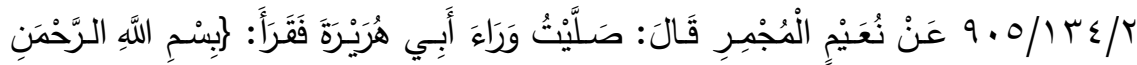

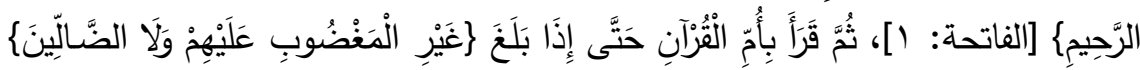

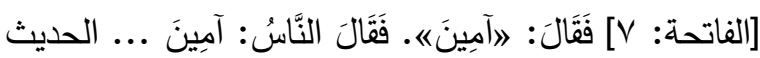

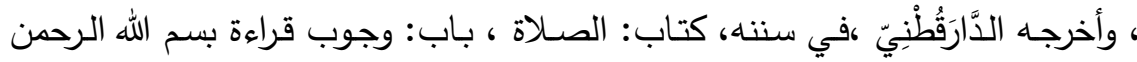

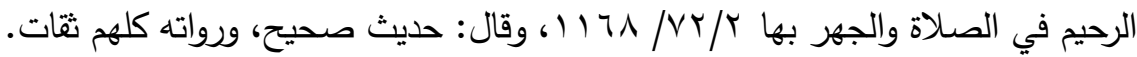

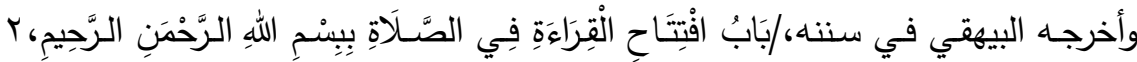
• قال الزيلعي: والجواب عنه من عدة وجوه: أحدها:أنسه حديث معلول، فإن ذكر البسملة

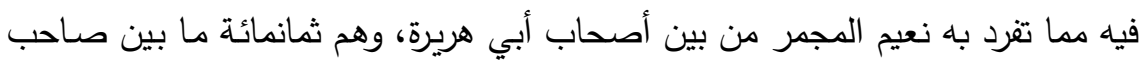

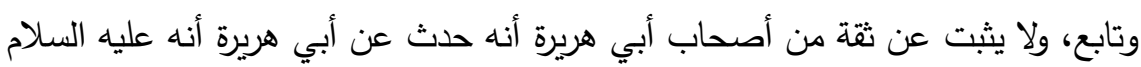

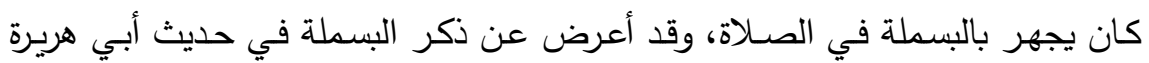

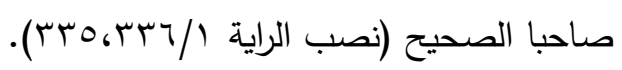

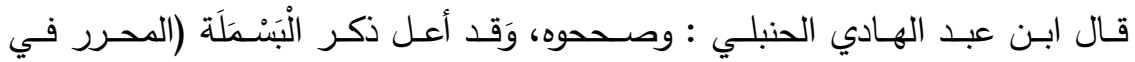

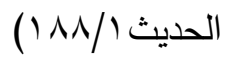

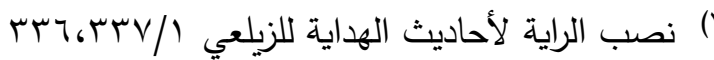


الزيادة على عاهنها في كل الأحوال، وإن صرحوا لفظا بقبولها فربمـا يكون مرادهم قبول زيادة معينة بشروط تخصها، فقد صرح البخاري والدار قطني بقبول الزيادة ، وبالنظر في مصنفاتهم نراهما يقبلان زيادات ويردان أخرى كما أشار إليه ابن رجب.

قال ابن رجب: وذكر في الكفاية حكاية عن البخاري: أنه سئل عن حليث أبي إسحاق في النكاح بلا ولي - قال: والزيادة من الثقة مقبولة واسرائيل ثقة(1). وهذه الحكاية - إن صحت - فإن مراده الزيادة في هذا الحديث ، والا فمن تأمل كتاب تأريخ البخاري ت تبين لله قطعا أنه لم ير أن زيادة كل ثقة في الإسناد مقبولة، وهكا الارقطني يذكر في بعض المواضع: أن الزيادة من الثقة مقبولة ، ثم يرُّد في أكثر المواضع زيادات كثيرة من الثقات، ويرجح الإرسال على الإسناد، فدل على أن مرادهم زيادة الثقة مثل ئل تلك المواضع الخاصة ، وهي اذا كان الثقة مبرزا في الحفظ(؟).

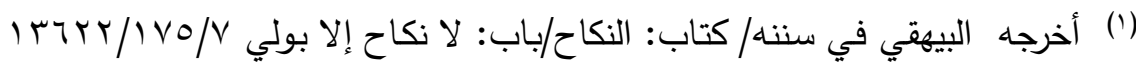

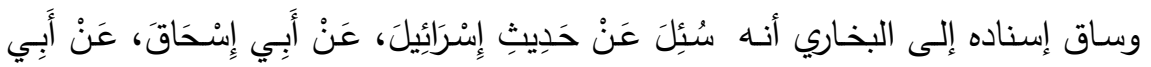

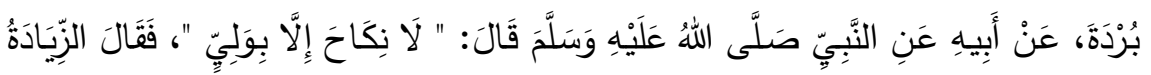

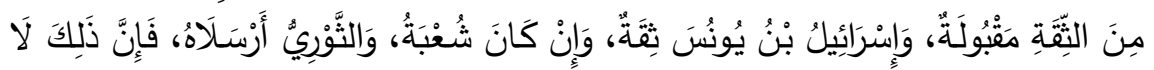

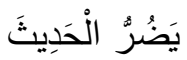
أي أن الحديث قد اختلف في وصله وإرساله ، فأرسله شعبة والثوري، ووصله إسرائيل بن

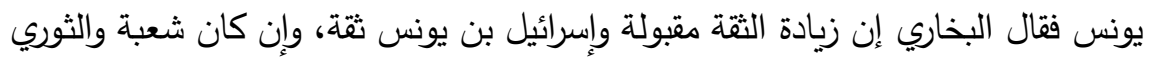
أرسلاه، فإن ذلك لا يضر الحديث. ل

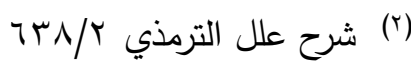


وقال ابن دقيق العيد: من حكى عن أهل الحديث أو أكثرهم أنه إذا تعارض إن رواية مرسل ومسند، أو رافع وواقف، أو ناقص وزائد، أن الحكم للزائد، فلم يصب في هذا الإطلاق، فإن ذلك ليس قانوناً مطرداً، وبمراجعة أحكامهم الجزئية يعرف صواب ما نقول (1)

وقال ابن حجر: الذي يجري على قواعد المحدثين أنهم لا يحكمون عليه بحمم مستقل من القبول والرد، بل يرجحون بالقرائن كما قدمناه في مسألة تعارض الوصل والإرسال(). قال: والمنقول عن أئمة الحديث المتقدمين: كعبد الرحمن بن مهدي ، ويحيى القطان، وأحمد بن حنبل، ويحيى بن معين، وعلي بن المديني ، والبخاري ، وأبي زرعة ، وأبي حاتم ، والنسائي ، والدارقطني، وغيرهم،

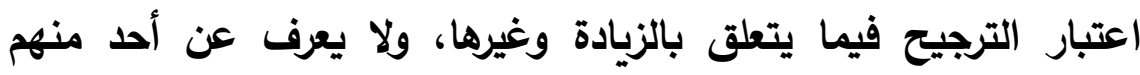
إطلاق قبول الزيادة(). وقال العلائي: الذي يظهر من كلامهم خصوصسا المتقدمين، كيحيى بن سعيد القطان، وعبد الرحمن بن مهدي، ومن بعدهما كأحمد بن حنبل، وعلي بن المديني، ويحيى بن معين، وهذه الطبقة ومن بعدهم، كالبخاري، وأبي زرعة، وأبي حاتم الرازيين، ومسلم، والترمذي، والنسـائي، وأمثالهم، شرح الإلمام بأحاديث الأحكام لتقي الدين أبو الفتح محمد بن علي بن وهب بن مطيع القشيري، المعروف بابن دقيق العيد (المتوفى: Y. P. هـ) حققه وعلق عليه وخرج أحاديثه: محمد خلوف العبد الله،

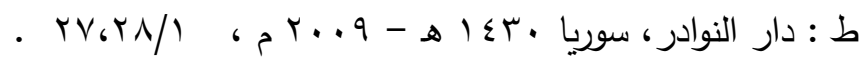

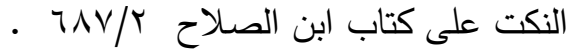

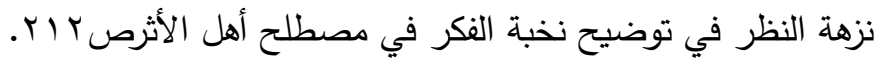


والدارقطني، والخليلي، كل هؤلاء مقتضى تصرفهم في الزيـادة قبولا وردا التـرجيح بالنسـبة إلـى مـا يقـوى عنـــ الواحـ مـنهم في كـل حـيث، ولا

يحكمون في المسألة بحم كلي يعم جميع الأحاديث، وهذا هو الحق(') . قلت: وبعد عرض هذه الآراء يتبين لنـا أنسه لا يمكن إطـلاق القول بـرد الزيادة أو قبولها مطلقـا أو حتى وضـع شروط عامـة لقبولها، فلكل زيـادة حكـم خـاص بهـا باعتبـار مـا تـرجح مـن القـرائن والملابســات المتعلقـة بالرواية. وذلك لأن الثقة يختلف ضبطه باختلاف الأحوال والأمساكن والثيوخ لخلل

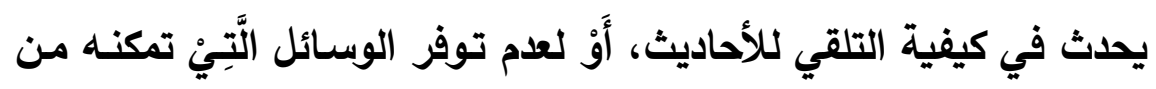
ضبط ما سَمعه من بعض شيوخه، أو لحدوث ضياع في بعض مـا كتبه

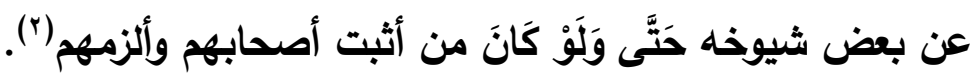
إذًا فضابط هذه المسألة مبني على ترجيح كون من زاد قد ضبط وحفظ مـالم يحفظه الآخرون في هذه الروايـة بعينها فحينئذ تقبل زيادتـه ، أم

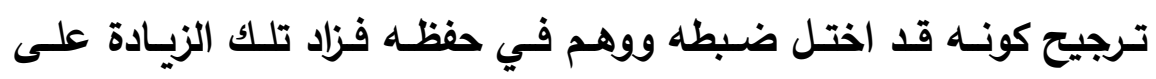
الآخرين فترد زبادته، وعلى هذا فليس للمسألة حكم مطرد كما قال البقاعي في مسألة تعارض الوقف والرفع معقبا على ابن الصلاح: على أنَّ لحذاقي المحدَثينَ في هذهِ المسـألكِة نظراً آخرَ لم يحكـهِ، وهوَ الذي لا ينبفي أنْ

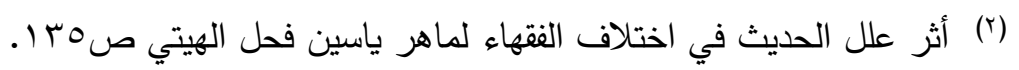


يُعدلَ عنهُ، وذلكَ أنهم لا يحكمونَ فيها بحكمٍ مطّردٍ، وإنما يدورونَ في ذَلِكَ

معَ القرائنِ (1) قلت: وهو مـا سـار عليه كبار الحفاظ والمحدثين كالإمـام البخاري ، وقد ضرب الحافظ ابن حجر مثالين تطبيقيين للإمام البخاري في مسألة تعارض الوصل والإرسال ، قدم البخاري في إحداها الإرسـال على الوصل، وقدم في الأخرى الوصل على الإرسال، لقرائن ظهرت لـه، ثم قال الحافظ ابن حجر: فصوب الإرسـال هنا لقربنة ظهرت لله فيه، وصوب المتصل هناك لقربنـة ظهرت لـه فيه، فتبين أنـه ليس لـه عمل مطرد في ذلك ، والله أعلم) آنمرن)

فلو روى عدد من الثقات حديثا عن شيخ ثقـة معروف بالفقـه والفتيا كمالك والثوري، والأوزاعي مثلا- وانفرد أحد الرواة بزيـادة، وهذه الزيـادة تنبني عليها قضية فقهية، وثبت أن فتيا ذلك الشيخ الفقيه تتطابق مـع الحديث خاليا من تلك الزيادة؛ فإن هذه قرينة ترجح رد الزيـادة أو التوقف عن قبولها؛ لأنه يتجه القول حينئ بأن تلك الزيادة لو كانت عنده لأفتى بموجبها. وهكذا"(r).

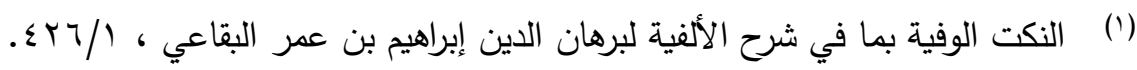

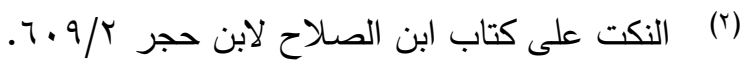
أثر علل الحديث في اختلاف الفقهاء لماهر ياسين الفحل صل . بـ نقلا عن كلام

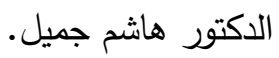


قال العلائي: ووجوه التَّرجيح كثيرة لا تنحصر، ولا ضابط لها، بالنسبة إلى جميع الأحاديث، بل كلٌ حديث يقوم بـه ترجيع خاص، وإنما ينهض بذانلك الممارس الفطن، الذي أكثر من الطرق والروايات('). وما أحسن قول الحافظ ابن رجب: حذاق النقاد من الحفاظ لكثرة ممارستهم

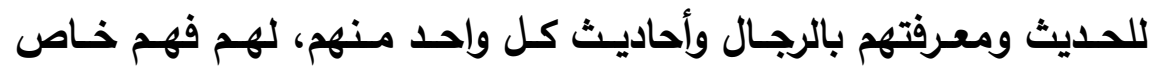
يفهمون بـه أن هذا الحديث يثببه حديث فـلان، ولا يثبه حديث فـلان، فيعللون الأحاديث بذلك. وهذا مما لا يعبر عنه بعبارة تحصره، وإنما يرجع فيه إلى أهله، إلى مجرد الفهم والمعرفة التي خصوا بها عن سـائر أهل (العلم (r) (1) (1) 


\section{الخاتمة}

وبعد هذا الجها المتواضع ، فهذه أهم النتائج التي توصلت إليها في هذا البحث:

1 - لابـد من وضـع ضوابط لتحديد ماهية مصطلح زيـادة الثقة ،والفصل بينهـه وبين وبين غيره، فـلا تلدخل زيـادات الصحابة بعضهم على بعض ضمن زيادة الثقة،وإنما تكون زيـادة الثقة عند صدورها من التابعين فمن بعدهم عند اتحاد مخرج الحديث، كما تخرج الزيـادة من دائرة زيـادة الثقـة إلى دائرة اختلاف الرواة لو تابع راوي الزيادة راو آخر، فروى تلك الزيادة ، فتصبح هذه الزيادة محفوظة فتزداد قوتها ، وببعُدَ اتهام الراوي بالإيهام والغلط بمتابعة غيره له .

r - إن مبحث زيادة الثقة ليس مبحثا مستقلا منفصلا عن غيره من أنواع علوم الحديث، وإنما يتعلق بغيره من العلوم الحديثية ذات الصلة الوثيقة

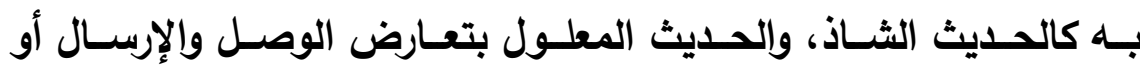
بتعارض الرفع والوقف، وإن لم يُجمعوا في كتب التراث الحديثية في وحدة موضـوعية إلا أن المحدثين أنفسهم قد أشـاروا إلى تـاخل هذه الأنـواع وتعلقها ببعضهها ، فلابـد من عرضـها ودراستها بوحدة موضوعية، منعـا للتناقض والتعارض فى الحكم عليها ل r- بين الثـاذ وزيـادة الثقـة عمـوم وخصـوص وجهي، فالثـاذ هو أحـا أقسام زيادة الثقة، فإذا كانت هذه الزيادة التي تفرد بها الثقة مخالفة لمـا رواه من هم أوثق منه وأحفظ ، أصبحت هذه الزيـادة روايـة شـاذة، إذ حـ

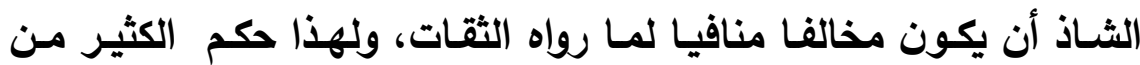
المحدثين برد الزيادة المخالفة لرواية الثقات لشذوذها ـ 
ع-يفرق بين المزيــ في متصل الأسـانيد، وبين زيـادة الثقـة في الإسـناد بالنظر في الإسناد الخالي من الزيادة، فإن كان الإسناد الخالي من الزيـادة متصلا، وصرح فيه بالسماع أو التحديث ، كانت الزيادة في الإسناد الآخر من قبيل المزبد في متصل الأسـانيد ، ويكون هذا المزيـ صحيحا و يقبل الإسـنادين لاتصـالهما ، إلا إذا دلت القرائن على وهم الـراوي في الإسـناد المزيد فيكون مرجوحا ـ أما إن كان الإسناد الخالي من الزيادة معنعنا عن إلن شـيخه و لـم يُصَسرح فيـه بالســاع فإِــه يكون معلـولا بتعـارض الوصـل

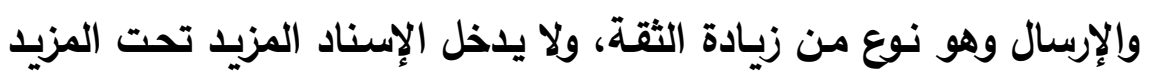

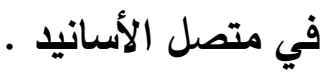

ه - ثمـة اختلاف كبير بين المحدثين والفقهاء في مسألة قبول زيـادة الثقة، وما صرح به الخطيب عن جمهور المحدثين بقبول زيـادة الثقة ، مشـروطا بكـون الـراوي عـلا ضــابطا، بخـلاف الفقهـاء الــين يشـترطون العدالة فقط ، وهو ما نص عليه الحافظ ابن حجر · צ-كما نوزع الخطيب البغدادي والنووي فيما نصا عليه من أن مذهب جمهور المحدثين هو قبول زيـادة الثقة، فإطلاق بعض المحدثين القول بأن الزيادة من الثقة مقبولة ليس قولا مطلقا منهم في كل زيادة، حتى وإن

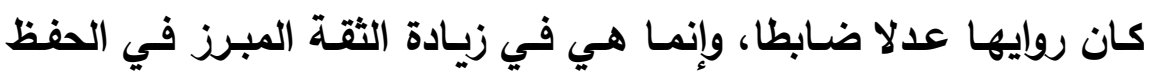
والإتقان على غيره ، ويظهر هذا جليا من خـلال تطبيقاتهم العمليـة في مصنفاتهم،

V-ע يمكن إصدار حكم كلي لقبول زيـادة الثقة أو ردها أو حتى وضـع شروط عامة لقبولها أو ردها ، وإنما لكل زيـادة في كل رواية حكم خاص بها من حيث القبول أو الرد، وفقا لما ترجح من الملابسـات والقرائن التي ردي 
يُحكـم بمقتضـاها علـى راوي الزيـادة بأنـه قـ أتقـن وحفظ مـالم يحفظـه الآخرون فتقبل زيادته،أو أنه قد وهم واختل ضبطه فروى هذه الزيادة التي لم يروها الآخرين فترد زيادته.

\section{توصية}

1-أوصي إخواني وأخواتي من الباحثين والباحثات بقسم الحديث وعلومسه بعمل دراسة تطبيقية لزيادة الثقة في بعض المصنفات الحديثية ، والوقوف

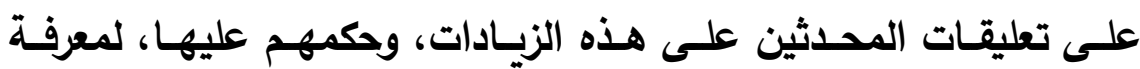
منهجهم في قبول الزيادة أو ردها عمليا. وتوظيف ذلك في الفهم الصحيح لأقوالهم النظريـة. r-كما أوصي بضرورة تناول أنواع علوم الحديث المتعلقة ببعضها بدراسة تتسم بالوحدة الموضوعية ، وسـهولة العرض ، ليسهل فهم هذه الأنواع كويُزَال عنها ما قد يشوبها من غموض أو تناقض . هذا وما كان من توفيق في هذا البحث فمن الله، ومـا كان من نقص، أو

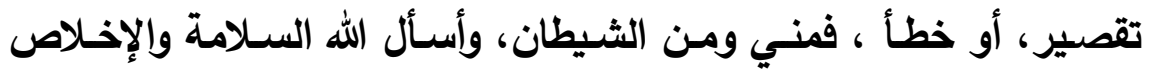

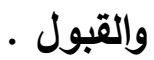
وآخر دعوانا أن الحمد لله رب العالمين. 
فهرس الموضوعات

المقدمة

$$
\text { سبب اختيار موضوع البحث }
$$

المبحث الأول:_تعريف زيادة الثقة وضوابطها

$$
\text { تعربف زيادة الثقة }
$$

ضوابط ماهية زيادة الثقة

المبحث الثاني : العلاقـة بين زيـادة الثقـة وبـين غيرهـا من أنـواع علوم الحديث

أولا: العلاقة بين زيـادة الثقة والحديث المعلول بتعارض الوصل والإرسـال أو الرفع والوقف أولف

ثانيا: العلاقة بين زيادة الثقة والحديث الثاذ ثالثا: العلاقة بين زيادة الثقة والمزيد في متصل الأسانيد المبحث الثالث : حكم زيادة الثقة الرأي الأول: رد الزيادة مطلقا الرأي الثاني : قبول الزيادة بشروط

الرأي الثالث: قبـول الزيـادة مطلقـا على كل الوجـوه مـادام راويهـا حافظـا ضابطا الرأي الرابع :اعتبار الترجيح بالقرائن 
القـول بـأن قبـول الزبـادة مـذهب لجمهـور المحدثين، والـرد على ذلـك، ومناقشة الآراء وتفنيدها، وبيان الراجح منها

الخاتمة

فهرس الموضوعات

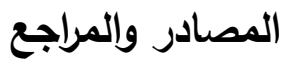




\section{المصادر والمراجع}

-أثر علل الحديث في اختلاف الفقهاء لماهر ياسين فحل ، تحقيق :هاشم

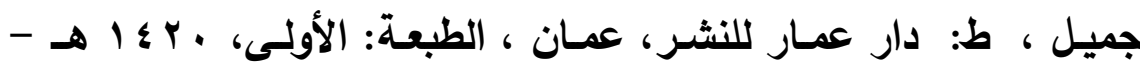
. r...

-الإحسان في تقريب صحيح ابن حبان لمحمد بن حبان بن أحمد بن حبان بن معاذ بن مَعْبَ، التميمي، أبو حاتم، الدارمي، البُستي (المتوفى ؛ هـهـ)ترتيب: الأمير عـلاء الدين علي بن بلبان الفارسي (المتوفى: 

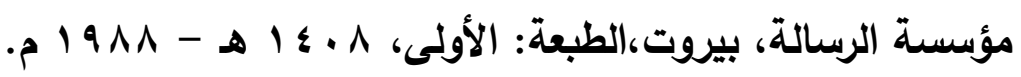
-الاقتراح في بيان الإصطلاح لتقي الدين أبو الفتح محمد بن علي بن وهب بن مطيع القشيري، المعروف بابن دقيق العيد (المتوفى: r • Vهـ) ، ط: دار الكتب العلمية - بيروت.

-الباعث الحثيث إلى اختصسار علوم الحديث لأبسي الفداء إسـماعيل بن عمر بن كثير القرشي البصري ثم الدمشقي (المتوفى: \&VV \&ه) تحقيق: أحمـد محمـد شــاكر، طا دار الكتب العلميـة، بيـروت - لبنان/الطبعـة: الثانية.

-البحر المحيط في أصول الفقه لأبي عبد الله بدر الدين محمد بن عبد الله بن بهادر الزركثي (المتوفى: ؟ 9 \هـ)، دار الكتب، الطبعة: الأولى، . $99 \leq-\infty 1 \leq 1 \leq$ 
- تاريخ الثقات للعجلي أبي الحسن أحمد بن عبد الله بن صـالح الكوفى

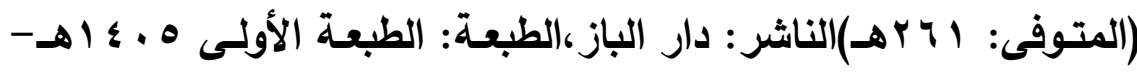
- ) $9 \wedge \varepsilon$

- تدريب الراوي في شرح تقريب النواوي لعبد الرحمن بن أبي بكر، جـلال الـدين السـيوطي (المتـوفى: 11 9هـ) تحقيـق: أبـو قتيبـة نظـر محمــ

$$
\text { الفاربابي/ ط: دار طيبة . }
$$

-تقريب التهذيب لأبي الفضل أحمد بن علي بن محمد بن أحمد بن حجر العسقلاني (المتوفى: بهـ rهـ)، تحقيق:محمد عوامـة، الناشر: دار الرشيد

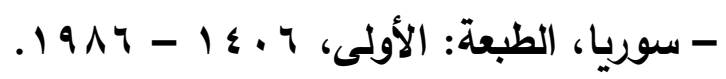
-التقريب والتيسير لمعرفة سنن البشير النذير في أصول الحديث لأبي

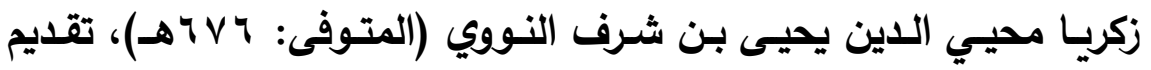
وتحقيق وتعليق: محمد عثمان الخشت ، ط: دار الكتاب العربي، بيروت

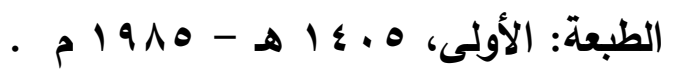

-التمهيد لما في الموطأ من المعاني والأسانيد لأبي عمر يوسف بن عبد الله بن محمد بن عبد البر بن عاصم النمري القرطبي (المتوفى: با7 ؛هـ) ، تحقيق: مصطفى بن أحمد العلوي ، محمد عبد الكبير البكري ، ط: وزارة

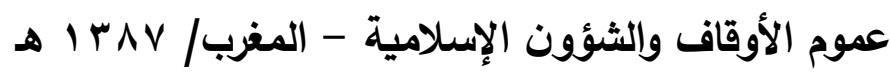
- تنقيح التحقيق في أحاديث التعليق لشمس الاين محمد بن أحمد بن عبد الهادي الحنبلي (المتوفى: ؟ \& V هـ)تحقيق: سامي بن محمد بن جاد

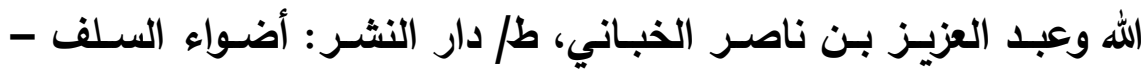
الرياض. 
-توجيه النظر إلى أصول الأثر لطاهر بن صـالح بن أحمد بن موهب،

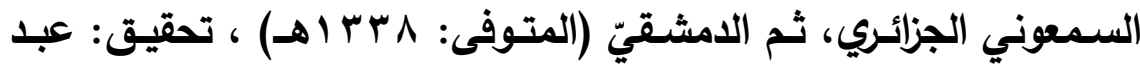
الفتاح أبو غدة، ط/ مكتبة المطبوعات الإسلامية - حلب الطبعة: الأولى، - $1990-81 \leqslant 19$

-الجامع المسند الصحيح المختصر من أمور رسول الله صلى الله عليه وسـلم وبنته وأيامسه ( صحيح البخاري) لمحمد بن إسماعيل أبو عبدالله البخـاري الجعفي، تحقيق: محمد زهير بـن ناصـر الناصـر، الناشـر : دار طوق النجاة (مصورة عن السلطانية بإضـافة ترقيم ترقيم محمد فؤاد عبد

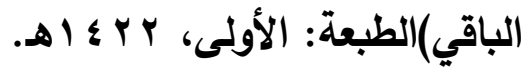

--الجوهر النقي على سـن البيهقي لعلاء اللاين علـي بـن عثمـان بـن إبـراهيم بـن مصـطفى المـارديني، أبـو الحسـن، الثـهير بـابن التركمـاني

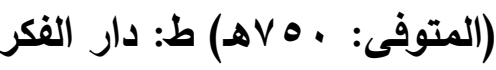

- دستور العلمـاء (جامع العلوم في اصطلاحات الفنون) للقاضسي عبد النبي بـن عبد الرسـول الأحمد نكري (المتوفى: ق r ا اهـ)عرب عباراتهـ الفارسية: حسن هاني فحص ، ط: دار الكتب العلمية - لبنان / بيروت

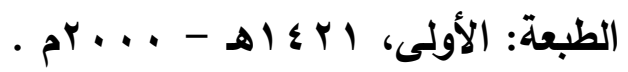

- زيادة الثقة في كتب مصطلح الحديث دراسـة موضوعية نقدية للدكتور

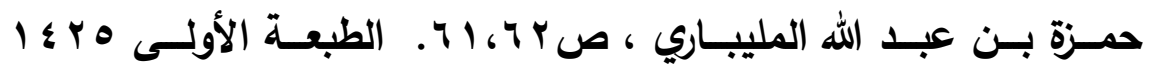
(ملتقى أهل الحديث ). 
سنن أبي داود لأبي داود سليمان بن الأشعث بن إسحاق بن بشير بن شداد بن عمرو الأزدي السِِِِّنْتاني (المتوفى: ه ه هـ) /تحقيق: محمد محيي الدين عبد الحميد، ط: المكتبة العصرية، صيدا - بيروت

سـنن الترمـذي لمحمــ بـن عيسـى بـن سَوْرة بـن موسـى بـن الضـحاك،

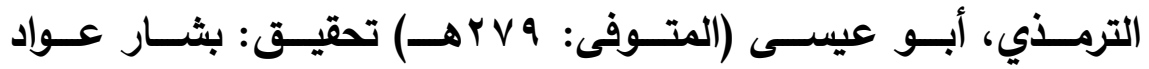
معروف،الناشر: دار الغرب الإسلامي - بيروت، سنة النشر: 991 م م سـنن الدارقطني لأبي الحسن علي بـن عمر بن أحمد بن مهدي بن

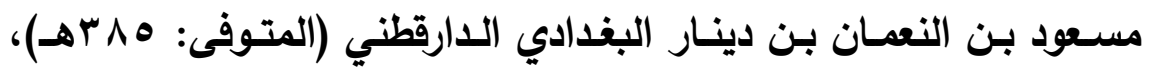
حققه وضبط نصه وعلق عليه: شعيب الارنؤوط، حسن عبد المنعم شلبي، عبد اللطيف حرز الله، أحمد برهوم، الناشـر: مؤسسـة الرسـالة، - لبنـان

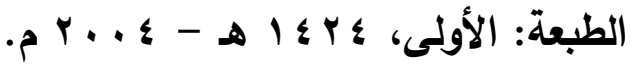

-السنن الكبرى للبيهقي أبو بكر أحمد بن الحسين بن علي بن موسى

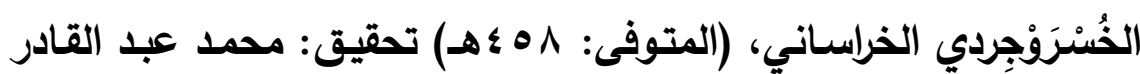

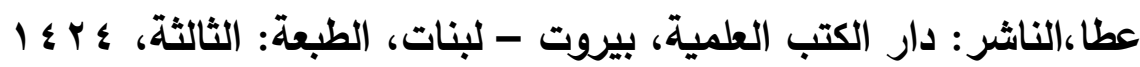
هـ -الشاذ والمنكر وزيادة الثقة - موازنة بين المتقدمين والمتأخرين لأبي ذر عبد القادر بن مصطفى بن عبد الرزلق المحمدي ط: دار الكتب العلمية،

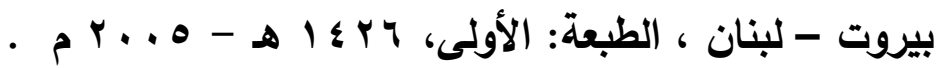
-شرح الإلمام بأحاديث الأحكام لتقي الدين أبو الفتح محمد بن علي بن وهب بن مطيع القشيري، المعروف بابن دقيق العيد (المتوفى: r · هـ 
حققه وعلق عليه وخرج أحاديثه: محمد خلوف العبد الله، ط : دار النوادر،

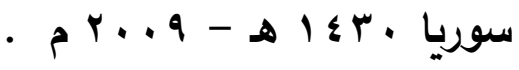
-شرح التبصرة والتذكرة لأبي الفضل زين الدين عبد الرحيم بن الحسين بن عبد الرحمن بن أبي بكر بن إبراهيم العراقي (المتوفى: ج ، 1هـ) ،

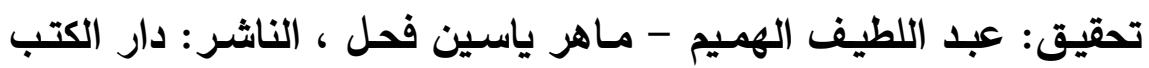

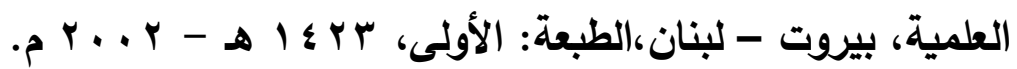

-شـرح علل الترمــي لـزين الدين عبد الـرحمن بـن أحمد بـن رجب بـن الحســن، السَــلامي، البغـــادي، ثــــ الامشـقـي، الحنبــــي (المتــوفى: ه V 9 هـتحقيق: الدكتور همام عبد الرحيم سعيد/ مكتبة المنـار - الزرقاء

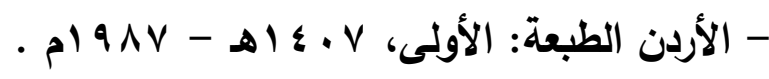
-شرح نخبة الفكر في مصطلحات أهل الأثرلعلي بن سلطان محمد، أبو الحسـن نـور الدين المـلا الهـروي القـاري (المتوفى: ؛ 1 ـ اهـ) ، حققــه وعلق عليه: محمد نزار تميم وهيثم نزار تميم ، طا دار الأرقم - لبنان/ بيروت.

-الغاية في شرح الهداية في علم الرواية للسخاوي، تحقيق : أبو عائش

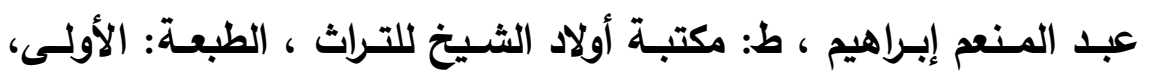
. Y.. 1

-فتح المغيث بشرح الفية الحديث للعراقي لشمس الدين أبو الخير محمد بن عبد الرحمن بن محمد بن أبي بكر بن عثمـان بن محمد السخاوي

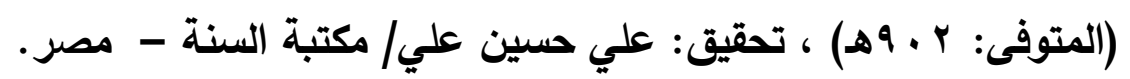


-الفصل للوصل المدرج في النقل للخطيب البغدادي (المتوفى: بآ ؛ــ) تحقيـق: محمــ بـن مطـر الزهرانـي، ط: دار الهجـرة الطبعـة: الأولــى، م) $99 \vee / ه 1 \leq 11$ -الكفاية في علم الرواية لأبي بكر أحمد بن علي بن ثابت بن أحمد بن

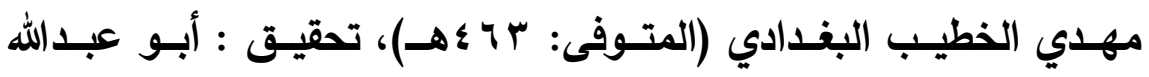
السورقي ، إبراهيم حمدي المدني ، ط: المكتبة العلمية - المدينة المنورة. -لسـان العرب لابن منظور(المتوفى: 1 |Vهـ) طا دار صـادر - بيروت|

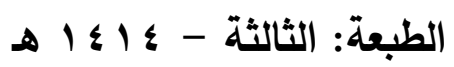

-المجتبى من السنن ( السنن الصغرى للنسائي)لأبي عبد الرحمن أحمد بن شعيب بن علي الخراساني، النسائي (المتوفى: r · rهـ)، تحقيق: عبد الفتاح أبو غدة، الناشر : مكتب المطبوعات الإسـلامية - حلب ، الطبعة:

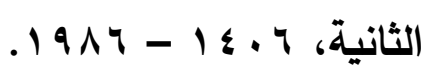

-المحرر في الحديث لثـمس الدين محمد بـن أحمد بـن عبد الهادي

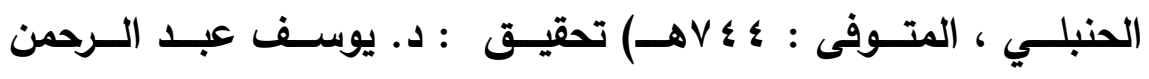
المرعشـي، محمد سليم إبراهيم سـمارة، جمـال حمدي الذهبي ، ط : دار

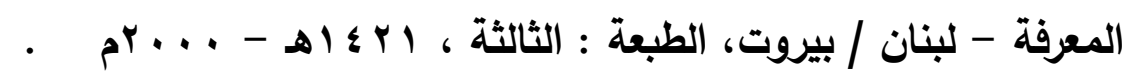
-المسند الصحيح المختصر بنقل العدل عن العدل إلى رسول الله صلى الله

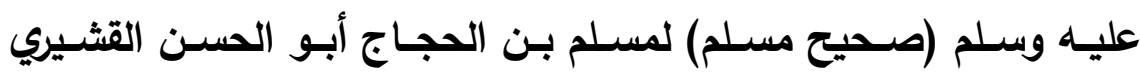
النيسابوري (المتوفى: آY Iه)، تحقيق: محمد فؤاد عبد الباقي ، الناشر: دار إحياء التراث العربي - بيروت . 
-معجم في المصطات والفـروق اللغويـة لأيـوب بـن موسـى الحسيني

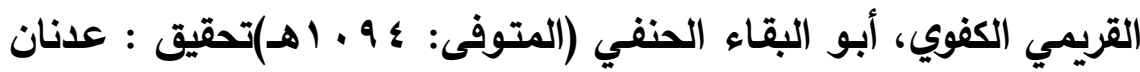
درويش - محمد المصري ، ط: مؤسسة الرسالة - بيروت . -معجم مقاييس اللغة لأحمد بن فارس بن زكرياء القزويني الرازي، أبو الحسين (المتوفى: هو هـ) ، تحقيق: عبد السـلام محمد هارون/ ط: دار

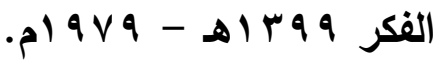

-معرفة أنواع علوم الحديث، (المعروف بمقدمـة ابن الصـلاح) تحقيق : نور الدين عتر،ط/، دار الفكر المعاصر - بيروت، سنة النشر: 7 ، ؛ اهـ -

- معرفـة الســن والآتــار لأحمــــــن الحسـين بـن علـي بـن موسـى

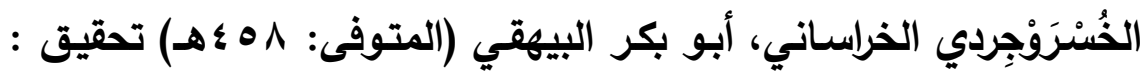

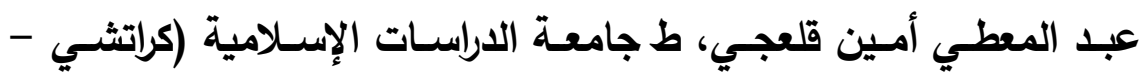
باكستان)، دار قتيبة (دمشق -بيروت)، دار الوعي (حلب - دمشق)، دار

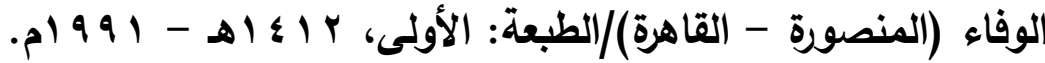
-معرفة علوم الحديث لأبي عبد الله الحاكم محمد بن عبد الله بن محمد بن حمدويـه بن نُعيم بن الحكم الضبي الطهماني النيسـابوري المعروف له بابن البيع (المتوفى: ه ه ـ هـ)تحقيق : السيد معظم حسين/ ط دار الكتب

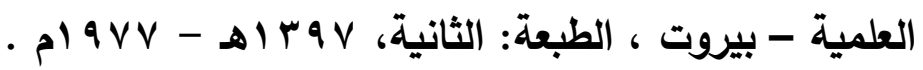

-المقترب في بيان المضطرب لأحمد بن عمر بن سالم بن أحمد بن عبود أبـو عمـر بـازمول السـلفي المكي الرحسابي/ط: دار ابـن حـزم للطباعـة

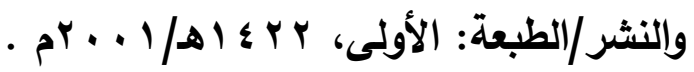


-المنهاج شرح صحيح مسلم بن الحجاج لأبي زكريا محيي الدين يحيى

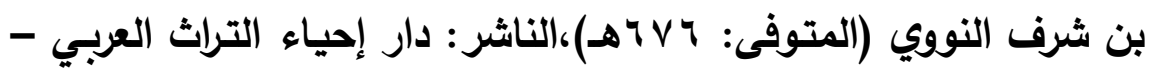

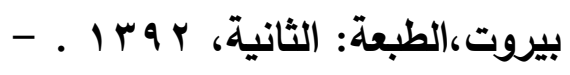

- نزهة النظر في توضيح نخبة الفكر في مصطلح أهل الأثر لأبي الفضل

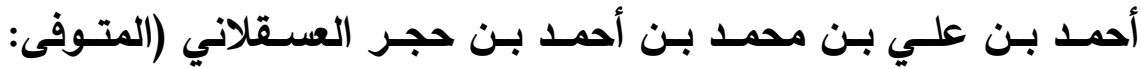

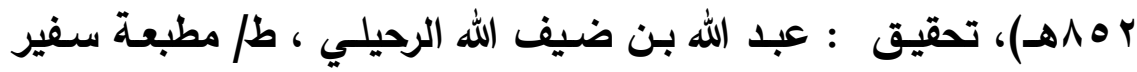

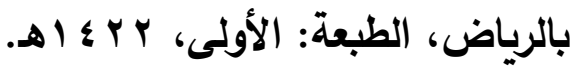

-نصب الرايـة لأحاديـث الهايـة مـع حاشيته بغيـة الألمعي في تخريج الزيلعي لجمـال الدين أبو محمد عبد الله بـن يوسف بـن محمد الزيلعي

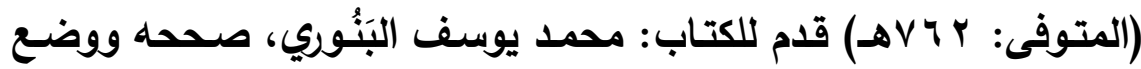
الحاشية: عبد العزيز الديوبندي الفنجاني، إلى كتـاب الحسج، ثم أكملها

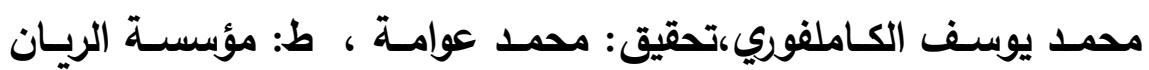
للطباعة والنشر - بيروت -لبنـان/ دار القبلة للثقافة الإسـلامية- جدة -

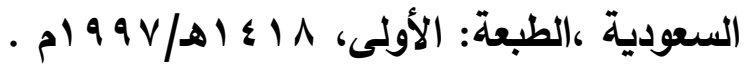

-النكت على كتاب ابن الصلاح لابن حجر العقلاني (المتوفى: ro اهــ) تحقيق : ربيع بن هادي عمير المدخلي/ط:عمادة البحث العلمي بالجامعة الإسدلامية، المدينة المنورة.

-النكت على مقدمة ابن الصلاح لأبي عبد الله بدر الدين محمد بن عبد

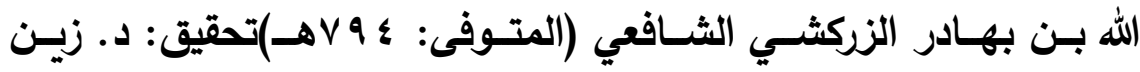
العابـدين بـن محمــ بـلا فـريج طا أضـواء السـلف - الريـاض، الطبعـة:

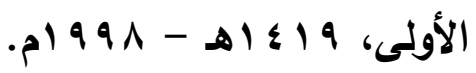


-النكـت الوفيـة بمـا في شـرح الألفيـة لبرهـان الـدين إبـراهيم بـن عمر البقاعي، تحقيق: ماهر ياسين الفحل

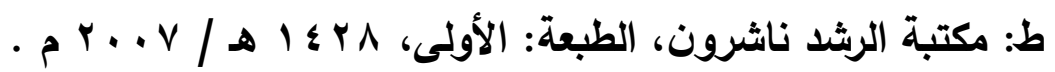
-نيل الأوطار لمحمد بن علي بن محمد بن عبد الله الشـوكاني اليمني

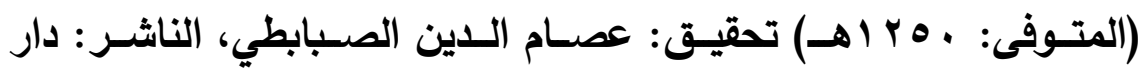

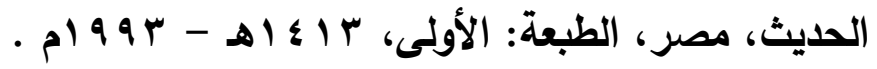

-اليواقيت والدر في شرح نخبة ابن حجر لزين الدين محمد المدعو بعبد الرؤوف بن تاج العارفين بن علي بن زين العابدين الحدادي ثم المناوي القـاهري (المتوفى: اسب • اهـ) تحقيق: المرتضسي الزين أحمد، ط: مكتبـة

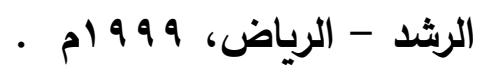


مباحث في زيادة الثقة

ب

$-$ 